\title{
RODOLFO WALSH, O CRIPTÓGRAFO. Relações entre escrita e ação política na obra de Rodolfo Walsh.
}

Silvia Beatriz Adoue

Tese apresentada ao Programa de Pós-Graduação em Língua Espanhola e Literaturas Espanhola e Hispano-Americana do Departamento de Letras Modernas da Faculdade de Filosofia, Letras e Ciências Humanas da Universidade de São Paulo, para obtenção do título de Doutor em Letras.

Orientador: Profa. Dra. Valeria De Marco 
UNIVERSIDADE DE SÃO PAULO

FACULDADE DE FILOSOFIA, LETRAS E CIÊNCIAS HUMANAS

DEPARTAMENTO DE LETRAS MODERNAS

PROGRAMA DE PÓS-GRADUAÇÃO EM LÍNGUA ESPANHOLA E LITERATURAS

ESPANHOLA E HISPANO-AMERICANA

\section{RODOLFO WALSH, O CRIPTÓGRAFO.}

Relações entre escrita e ação política na obra de Rodolfo Walsh.

Silvia Beatriz Adoue

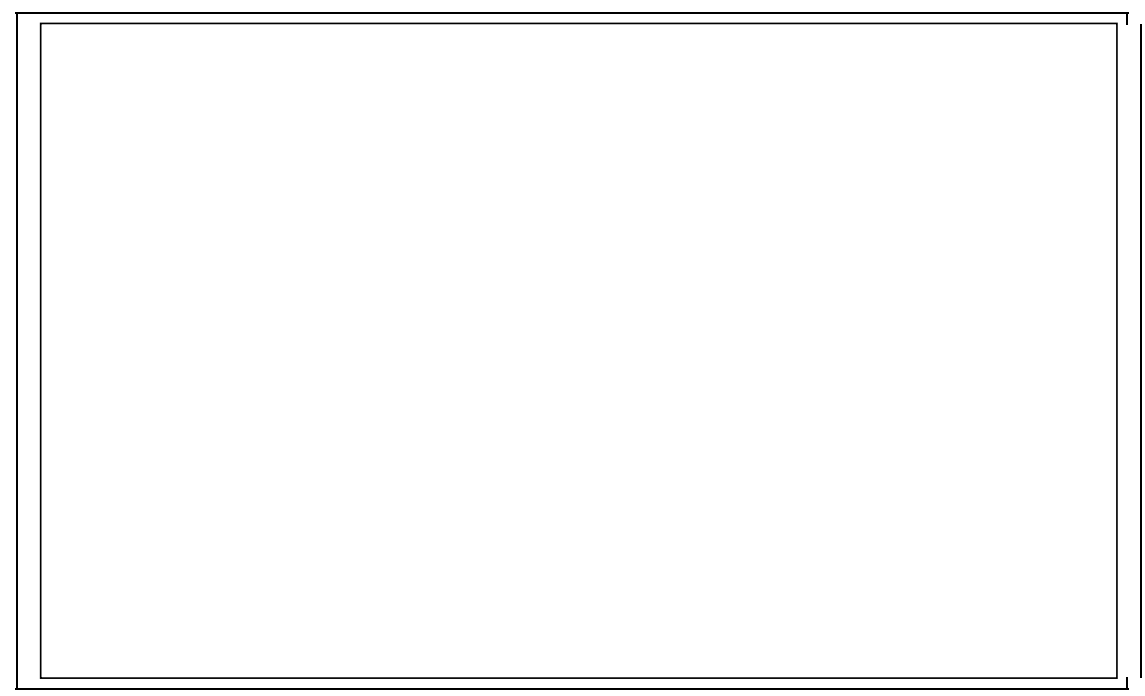

São Paulo

2008 
A Trini e Lilia, insurgentes de 1956.

A Olavo, sempre.

Aos compas. 


\section{Gracias}

Este trabalho aqui redigido é resultado de anos de trabalho. Mas ele não está redigido como um diário que registra essas jornadas de labuta. Se assim fosse, cada parágrafo estaria povoado de innúmeros nomes, daqueles que participaram das dúvidas e das descobertas e dos que deram as condições materiais para ir em frente. Quero deixar aqui registrados alguns desses nomes, sem explicar os motivos. Eles sabem. E nunca é um motivo só. Os nomes: Christina Diniz Leal, Valeria De Marco, Marilúcia Santos Teles, Cleide Santos Sá Teles, Murilo Leal Pereira Neto, Gladys Beatriz Barreiro, Lucía García, Darío Pignotti, Pedro Ortiz, Marco Fernandes, Lisandra Guedes, Héctor López Girondo, Lilia Santiago, Pablo Alabarces, Miguel Croceri, Olavo Adoue Leal, Susana Marta Lui, Adriana Brugués, Beatriz Collado, Silvana Lopes Zamproneo, Claudete Bassaglia, Giovanni Augusto Vieira, Ana Claudia da Silva, Heloisa Helena Reinert, Luciana Pinsky, Thaís Moll, Camila Moraes, Clóvis Zanettin Pereira, Heloísa Fernandes, Maria Dolores Aybar, Sergio Adoue, Tatiana Merlino, Dafne Melo, Augusto Juncal. Para todos eles, minha imensa gratidão. 


\section{RESUMO}

O presente trabalho é um estudo da poética do escritor, jornalista e militante argentino Rodolfo Jorge Walsh. Tradutor, editor e autor de relatos policiais, soube fazer da atividade literária um ato de reflexão sobre a história do seu país e da própria ação militante. Os procedimentos de escrita utilizados dentro da sua obra procuravam a eficiência persuasiva, mas também a eficiência na representação dos problemas que estavam colocados para o escritor na sua ação política. São objeto de estudo deste trabalho: a passagem do policial de enigma para o hard-boiled e o posterior abandono do subgênero; a opção pela forma breve do conto e não do romance; o abandono da escrita estritamente literária que seria retomada só nos últimos meses da sua vida -processos que coincidiram com o desenvolvimento de investigações sobre crimes de Estado e seu ingresso na militância- e a retomada da autoria, pouco antes de morrer, para a produção de uma série de cartas pessoais no contexto da ditadura que se iniciou em 1976 e da polêmica do autor com a direção da organização Montoneros, na qual militava.

Palavras-chave: Rodolfo Walsh; literatura argentina; jornalismo militante; literatura policial; literatura

e testemunho. 


\begin{abstract}
The present work is a study of Rodolfo Jorge Walsh's poetry. He was an author, a journalist and an activist. Also a translator, editor an author of police short stories. He knew how to transform the literary activity into an act of reflexion about the history of his country and the activist action itself. The writing procedures used inside his works searched not only for a persuasive efficiency, but also the efficiency in representing the problems faced by the author in his political action. They are object of study: the passage from police enigma to hard-boiled and the following desertion of the sub gender; the option for the brief form of the short story and not the novel; desertion of the writing strictly literary that would be taken up again in the last months of his life - processes that coincided with the development of State crime investigations and his participation in an activist life - and getting back the authorship, shortly before his death, into a production of personal letters in a dictatorship context that began in 1976 and the controversy of the author in relation to the direction of the Montoneros organization, for which he was an activist.
\end{abstract}

Key words: Rodolfo Walsh; Argentinian Literature; Activist Journalism; Police Literature; Literature and Testimony. 


\section{SUMÁRIO}

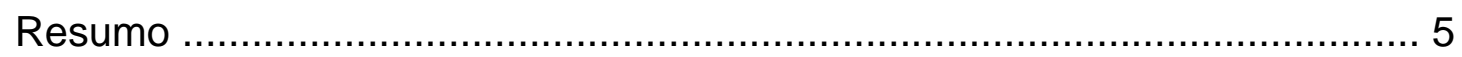

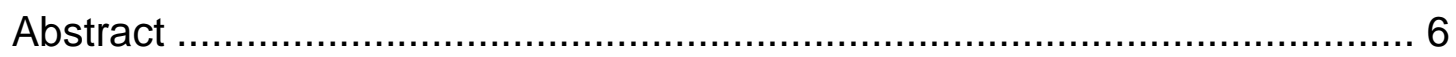

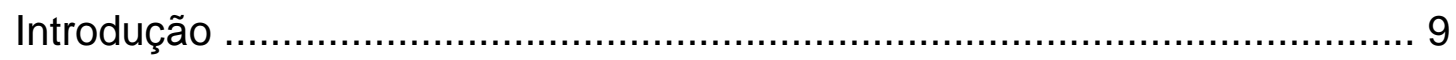

Capítulo 1: A literatura policial. Entre Hunter e o profeta Daniel ................... 17

Las tres noches de Isaías Bloom. O policial de enigma ............................. 17

La aventura de las pruebas de imprenta. A imersão nas fontes ................... 28

Zugwang. Transposición de jugadas. En defensa propia. Um ponto de inflexão: do policial de enigma ao hard-boiled ........................................... 37

Do relato policial ao relato testemunhal ................................................... 48

Capítulo 2: A trilogia de investigação. Jornalismo, testemunho e militância . 53 As particularidades da obra investigativa de Walsh .................................... 62

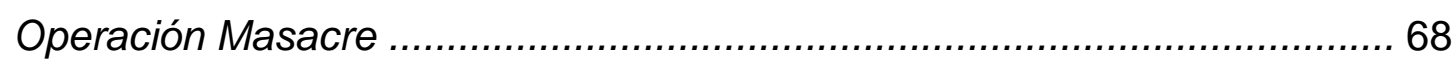

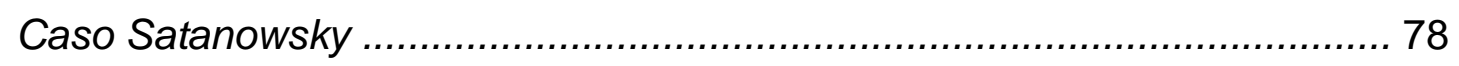

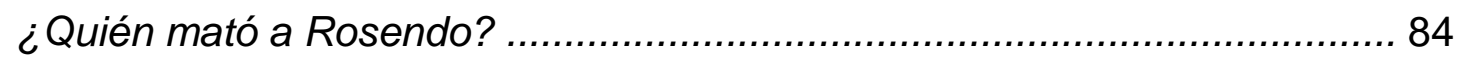

A poética da investigação e da escrita ................................................... 95

Capítulo 3: Literatura: "un avance laborioso a través de la propia estupidez" 100

Los ojos del traidor. Como narrar a violência? .......................................... 105 
La máquina del bien y del mal. A escrita como um ofício e a captura da voz do não letrado como ato político

110

Nota al pie. A batalha pelo sentido.

A "série dos irlandeses". As relações de poder e o fim do herói individual ..123 Imaginaria. Astúcia como inteligência de pobre

127

Esa mujer. Obra literária e peça de inteligência 131

Os contos como espaço de experimentação 135

Capítulo 4: As cartas pessoais 138

Carta a Vicky. Carta a mis amigos 142

Carta abierta a la junta militar 150

Considerações Finais 162

Referências Bibliográficas 169

Obra do autor 169

Bibliografia geral 175

Anexos 188

Carta a Vicki 189

Carta a mis amigos 191

Carta abierta a la junta militar 196 


\section{INTRODUÇÃO}

No es un arma guardada que rememora los disparos, sino un hacer violento, en los cuales la escritura agrede la molicie y espanta los oropeles.

Daniel Camels.

Argentino de família irlandesa, nascido em 1927, educado na fé católica, escritor de relatos policiais e jornalista primeiro, militante depois, Rodolfo Jorge Walsh aproxima-se da realidade com o olhar indagador do detetive e do exegeta. Para ele, os fatos escondem e insinuam, dão pistas. Há uma verdade ocultada pelo relato hegemônico e que é preciso que venha à tona. A principal tarefa de Walsh será revelá-la. Aos procedimentos ideológicos que constroem o relato hegemônico, o militante/escritor oporá uma série de procedimentos literários que constituem as ferramentas do seu ofício de "criptógrafo" e inauguram um registro estético, uma poética. Estudar essas ferramentas, balizar esse registro, reconhecer essa poética são os objetivos deste trabalho.

\section{§§§§§}

No dia 10 de junho de 1956, em Buenos Aires, uma mulher viaja no banco do fundo de um ônibus urbano. $\mathrm{O}$ motorista tem o rádio ligado. $\mathrm{O}$ locutor do informativo anuncia que o levantamento cívico-militar que pretendia restaurar o governo peronista derrubado com um golpe militar no ano anterior foi debelado e muitos dos seus quadros presos ou fuzilados. A mulher também está envolvida no putch. Tem, num dos quartos da pensão onde mora, um mimeógrafo caseiro. Nos dias anteriores rodou alguns panfletos e distribuiu-os aos seus companheiros por meio de um homem que não sabe 
de nada, mas que a ama. Desmaia. Os outros passageiros ajudam a reanimá-la, solidários: não é a única que lamenta o fracasso da ação e todos temem pelas represálias do governo aos peronistas, ou aos pobres, o que naquelas circunstâncias vem a ser a mesma coisa. Por via das dúvidas, a mulher consulta um médico. Ele Ihe anuncia: está grávida. Em fevereiro de 1957, nascerá sua filha e a mulher abandonará a militância.

\section{§§§§§}

Na noite anterior, em La Plata, um partidário da Revolución Libertadora -nome que se dava a si mesmo o governo de facto- estava jogando xadrez num bar quando ouviu uns tiros. A notícia de um putch o levou para seu bairro, no meio do enfrentamento entre militares leais e sublevados. Os sublevados permitiram-Ihe chegar à sua casa. O portal dela foi utilizado pelos leais para defender posições. Com a luz desligada, através da persiana, ouviu as últimas palavras sussurradas por um soldadinho agonizante: “No me dejen solo, hijos de puta!”. Esta fala o incomoda, dói- Ihe, há alguma coisa errada. O soldadinho estava ali cumprindo o serviço militar obrigatório, não se identificava com os leais; tampouco era um sublevado.

Algum desequilíbrio se produz no enxadrista, única testemunha, involuntária, da morte do soldado. Pouco tempo depois, estará investigando os fuzilamentos daquela mesma noite. Virará militante peronista, chamará o golpe que derrubou Perón de Revolución Fusiladora, nome com que se lembrará daquele período pós-peronista. Dedicará o resto da sua vida a 
desvendar uma verdade vislumbrada às escuras, junto à janela da sua casa. Vinte anos depois, perderá sua filha primogênita num enfrentamento com os mesmos militares que antes tinham derrubado Perón. Ele próprio, emboscado, responderá ao fogo do inimigo com uma arma de pequeno calibre, será malferido e farão desaparecer seu corpo junto com os seus escritos inéditos.

Nascida em fevereiro de 1957, ouvi durante toda a infância, a narrativa popular daqueles acontecimentos de junho de 56. A narrativa incluía o relato do ocultamento dos fatos e a sua revelação pelo enxadrista, já transformado em jornalista militante. Vindo do campo contrário, tornou-se companheiro daqueles que resistiam ao governo iniciado em 1955, vencendo com sua palavra primeiro o silêncio e depois a versão oficial.

A narrativa popular é também narrativa dessa luta para se impor enquanto narrativa. Ela é, desde a sua origem, um "contra-relato". Uma narrativa 'forçada". A identificação das armas dessa luta, seus recursos, ocupa-me por razões que estão no cruzamento do pessoal com o coletivo, mas que, em todo caso, levam-me a tomar partido.

Este trabalho é resultado do estudo da obra e da biografia de Rodolfo Walsh na procura das linhas de tensão que definem sua poética. Para isso, fiz uma aproximação às temáticas recorrentes, como linhas de continuidade, mas que sofrem, ao longo da obra, permanentes metamorfoses, como as imagens de um caleidoscópio; fiz também um reconhecimento das formas de 
representação, enquanto apropriação de gêneros discursivos e vozes sociais que Walsh faz nos seus escritos, e estudei a circulação de procedimentos que vão da ação política e do texto de publicista à ficção e vice-versa, passando às vezes pelo ofício "simples" de tradutor.

Há temáticas, gêneros e vozes que percorrem a atividade literária, a jornalística e a militante do autor. Os objetivos deste trabalho são os de encontrar percursos que vinculem as três séries, uma vez que a poética de Walsh está inscrita nessa rede.

Alguns temas são revisitados pelo autor ao longo de sua obra, alguns são símbolos, metáforas, outros são assuntos mais gerais permanentemente metaforizados: o "soldadito", os ofícios, a violência institucional, o cadáver.

Esses temas são introduzidos como sinais que irrompem nas suas leituras, nas suas traduções e na sua história pessoal. São para Walsh sinais de uma escrita cifrada a decriptar. Esse olhar do autor sobre o real e sobre as suas leituras talvez possa ser atribuído a traços herdados de sua formação católica, vindos à tona repentinamente, convocados por eventos vividos como excepcionais. Em sua biografia, muitas vezes comparada à trajetória do profeta Daniel, nome com que assinou muitos dos seus escritos e que atribuiu ao protagonista de muitas das suas ficções, não faltaram pesadelos bíblicos, como a coluna de fogo que reitera a sua presença após a morte da sua filha primogênita. 
Os acontecimentos agem sobre Walsh como revelações que se propagam assumindo significados muito mais amplos. Essa relação do autor com os fatos é facilmente detectada no momento em que Jorge Masetti entrega para Walsh um telex recebido por engano, devido a um problema mecânico, na agência de notícias Prensa Latina. O escritor estava em Cuba, trabalhando num projeto jornalístico que ele ajudou a construir. O telex é uma mensagem cifrada da $\mathrm{CI}^{1}$ que indica o dia e lugar de desembarque da invasão da Bahia dos Porcos, em 1961, sob o comando norteamericano. Walsh consegue interpretá-la com a ajuda de um livro sobre escrita cifrada, comprado num sebo. Com essa experiência, ele descobre sua condição de criptógrafo, mesmo sem possuir conhecimento prévio ou talento especial para a profissão. O curioso é que, ao decifrar a mensagem, ele percebe que, conhecendo ou não o ofício, não fará outra coisa em toda sua vida².

Esses temas renitentes inscrevem-se na sua literatura como sinais a serem interpretados no decorrer da obra por autor e leitores. $\mathrm{O}$ autor os recolhe justamente por considerá-los núcleos de transparência emergindo no meio da opacidade do real, capazes de condensar verdades de profundidade. Não são para o autor construções da sua própria criação. Walsh os apresenta como impostos a ele de maneira implacável para que o autor e o seu leitor Ihes adivinhem o sentido.

O deciframento de enigmas constitui-se também, ele próprio, num dos temas da sua obra: na literatura policial, na sua obra investigativa, na sua

$1 \quad$ Central de Inteligência dos Estados Unidos.

2 Este episódio foi investigado em: ARROSAGARAY, Enrique. Rodolfo Walsh en 
atividade de inteligência na organização em que milita. Isto acontece porque a literatura, para Walsh, é também um lugar de reflexão individual e coletiva.

No seu texto autobiográfico, Walsh confessa: "La idea más perturbadora de mi adolescencia fue ese chiste idiota de Rilke. Si usted piensa que puede vivir sin escribir, no debe escribir" ${ }^{3}$. Mas foi esse mesmo motivo que levou o autor a retomar a escrita e não mais abandoná-la. Escrever tornou-se para ele um imperativo.

Walsh tinha começado -e abandonou- um curso de Letras. Lançou-se, porém, à escrita no jornalismo e na indústria cultural, que eram seu meio de vida. Seu ofício de tradutor colocou-o em contato com "a melhor literatura policial”. Mas sua relação com o gênero não era ingênua.

A obra investigativa do autor, de alguma maneira, é caudatária do gênero jornalístico e também da narrativa policial, de uma narrativa policial em que o jornalista é, por sua vez, detetive/narrador e que inclui as vozes de testemunhas, vítimas e suspeitos. Mas, pelo fato de os crimes investigados serem crimes de Estado, encontramos também, nessas obras de Walsh, elementos das narrativas de espionagem.

Muitas das características da sua escrita militante circulam na produção de caráter jornalístico e literário do autor. Tanto é assim que é muito difícil classificar algumas de suas obras, como é o caso das chamadas 
"cartas pessoais".

O estudo da produção de Walsh neste trabalho está organizado em quatro capítulos.

No primeiro capítulo, descrevem-se as mudanças na primeira parte da obra ficcional de Walsh, que começa com literatura policial de enigma, passa pelo hard-boiled para depois abandonar o gênero policial. No meio desse processo, encontramos as "intromissões" da literatura de espionagem, a testemunhal, a investigação jornalística e a reflexão existencial que leva 0 autor para a ação e a literatura militante.

O segundo capítulo é dedicado à obra investigativa de Walsh e reconhece a continuidade temática e formal com relação ao conjunto da obra do autor. Também é estudada a relação entre o processo de investigação e o de escrita, bem como a associação destes com a ação política do autor. Para isto, não posso deixar de considerar a circulação das obras e a recepção que elas tiveram e confrontá-las com as escolhas formais e a figuração da leitura esperada por Walsh.

O terceiro capítulo focaliza os contos do autor, que conformam a parte da sua obra considerada estritamente literária e que configuram um espaço de experimentação e reflexão sobre as formas mais adequadas inclusive para o conjunto dos seus textos. Mas estes contos também expressam certas 
linhas de tensão que vão pautar a atividade militante de Walsh: a questão da autoria, o lugar ocupado pelo intelectual, a produção de narrativas que se oponham às hegemônicas, as possibilidades de a literatura representar a realidade histórica e o seu vigor para agir sobre ela.

O quarto e último capítulo trata das chamadas "cartas pessoais" do escritor, produzidas nos últimos meses da sua vida e que revelam, pelas escolhas formais, soluções que o autor encontrou para algumas das tensões que pautaram o conjunto da sua obra ${ }^{4}$.

Para responder às indagações propostas, o estudo do corpus dedica atenção a alguns procedimentos de construção dos textos que o integram: descrição da composição das narrativas policiais, suas mudanças e o abandono dessa forma associado à militância de Walsh; análise de uso de estratégias próprias ao cânone testemunhal e análise dos modos de apropriação da oralidade e de gêneros discursivos.

$4 \quad$ Não vou focalizar neste trabalho as duas peças teatrais, nas quais Wlash tentou uma aproximação ao conjunto da América Latina. Nelas, ele escolheu um registro lingüístico de "castelhano neutro", que não aparece no restante da obra. Os enredos, porém, estão construídos como parábolas que condensam a maioria dos temas presentes na produção do autor. Tampouco vou analisar as matérias jornalísticas, ainda que nelas circulem procedimentos "ensaiados" nos outros gêneros freqüentados. 


\section{Capítulo 1: A literatura policial}

\section{Entre Hunter e o profeta Daniel}

Rodolfo Jorge Walsh, depois de interromper seu curso de Letras, chegou à atividade literária passando primeiro por ofícios vinculados à edição de literatura "menor": corretor, tradutor e adaptador de novelas policiais, de terror, de suspense, de espionagem. Inicialmente, foi tradutor, primeiro para a Serie Naranja e para a coleção Evasión, da editora Hachette, e para El Séptimo Círculo, da editora Emecé; depois, tradutor e adaptador para a revista Leoplán e para a Serie Negra, da editora Tiempo Contemporâneo. Provavelmente, como o personagem de um conto bem posterior, o tradutor León, de Nota al pie, o ainda tradutor e adaptador Walsh também sonhou em ser escritor.

Un día extravié medio pliego de una novela de Asimov. ¿Sabe qué hice? Lo inventé de pies a cabeza. Nadie se dio cuenta. A raíz de eso fantaseé que yo mismo podía escribir. ${ }^{5}$

\section{Las tres noches de Isaías Bloom.}

\section{O policial de enigma}

Em 1950, com vinte e três anos, Walsh publicou Las tres noches de Isaías Bloom, na revista Vea y Lea. Este, seu primeiro relato de ficção que chega às nossas mãos, Walsh havia apresentado quatro anos antes em um concurso organizado pela revista e pela editora Emecé. O júri, composto por 
Jorge Luis Borges, Adolfo Bioy Casares e Leônidas Barletta, atribuiu-lhe uma das menções honrosas.

No seu artigo Modelos, géneros y medios en la iniciación literaria de Rodolfo Walsh ${ }^{6}$, Eduardo Romano sugere tratar-se de um conto que coincide com as inclinações do júri. Chama a atenção para a filiação borgeana da narrativa e para uma homenagem a Barletta presente no lunfardo das vozes dos personagens. Se a primeira paternidade se tornará evidente, como se pode observar na comparação, ainda neste capítulo, entre Las tres noches de Isaías Bloom e La muerte y la brújula, escrito por Borges em 1942, o suposto tributo a Barletta coincide também com outra possível paternidade: a de Roberto Arlt.

Em 1948, Ernesto Sábato publicou pela primeira vez o romance El túnel. No enredo, Hunter, um aspirante a escritor, imagina um personagem que, como um Quixote do século $X X$, de tanto ler novelas policiais, vê o mundo como ele é representado nesse gênero e age como se ele próprio fosse um detetive de

novela. Por outro lado, na investigação do jornalista Enrique Arrosagaray, Rodolfo Walsh en Cuba: Agencia Prensa Latina, militancia, ron y criptografía, há uma entrevista a Juan Fresán na qual este último compara Walsh com o detetive Erik Lönnrot de La muerte y la brújula, que peca por excesso de literatura. Diz Fresán:

96.

6 ROMANO, Eduardo. "Modelos, géneros y medios en la iniciación literaria de Rodolfo J. Walsh". In: LAFFORGUE, Jorge et ALL. Textos de y sobre Rodolfo Walsh. Buenos Aires: Alianza, 2000, p. 73. 
[...] empieza con la literatura policial, después pasa al periodismo policial ficcionado y como el Quijote, que de tanto leer libros de caballería ve molinos de viento - y cree que son gigantes enemigos -, se vuelve loco y pasa de la ficción a la realidad pero jugando a la ficción, como una especie de Sherlok Holmes que se ponía narices postizas. Él mismo se disfrazaba cuando estaba perseguido. ${ }^{7}$

A propósito dessa comparação de Walsh com o Quixote, Jorge Lafforgue comenta:

Alguien que no lo quería mucho supo comentar que Walsh se parecía al Quijote: de tanto leer novelas policiales creyó ser uno de sus héroes de papel (más: su paranoia paródica le hizo acompañar la evolución del género, desde el fair-play hasta el hardboiled). Pues sí. Desestimemos el sarcasmo y demos vuelta el comentario: contra una realidad mentirosa se apelará a una escritura que la revela; y si el poder de la ficción pareciera no alcanzar, se echará mano de la denuncia política hasta sus últimas consecuencias. ${ }^{8}$

Mas, afinal, em que consistia esse excesso de literatura do detetive amador de Borges, depois atribuído a Walsh? No conto de Borges acontece um assassinato. O morto é um rabino. Os assassinos deixam uma pista falsa, uma frase que remete a um texto religioso: "la primera letra del Nombre ha sido articulada"9. O delegado de polícia, chamado Treviranus, procura uma motivação material: o rabino é possuidor das melhores safiras do mundo. $O$ jornalista Lönnrot é arrastado pela pista falsa e procura uma explicação espiritual. Erik Lönnrot diz ao delegado Treviranus:

7 FRESAN, Juan. Apud: ARROSAGARAY, Enrique. Rodolfo Walsh en Cuba. Agencia Prensa Latina, militancia, ron y criptografía. Buenos Aires: Catálogos, 2004, p. 50.

$8 \quad$ LAFFORGUE, Jorge. "Epílogo provisorio". In: e outros. Textos de y sobre Rodolfo Walsh. Buenos Aires: Alianza, 2000, p. 334.

9 BORGES, Jorge Luis. "La muerte y la brújula". In: Ficciones. Madrid: Alianza, 1998, p. 159. Neste capítulo, as referências a "La muerte y La brújula" que aparecem a seguir indicam as páginas desta edição. 
Usted replicará que la realidad no tiene la menor obligación de ser interesante. Yo le replicaré que la realidad puede prescindir de esa obligación, pero no las hipótesis. En la que usted ha improvisado, interviene copiosamente el azar. He aquí un rabino muerto; yo preferiría una explicación puramente rabínica, no los imaginarios percances de un imaginario ladrón. (p. 155)

Esse excesso levará Lönnrot à perdição. Red Scarlach, ladrão de safiras, armou para ele uma cilada literária para acertar velhas contas. Para Fresán, também Walsh enredou-se na cilada de acreditar que a vida era como nas novelas policiais, o que o teria levado à morte.

Em todo caso, a cilada de Scarlach foi a de representar a realidade como o faz o policial de enigma, com toda a sua beleza de labirintos simétricos, seqüências numéricas e losangos repetidos anunciando obsessivamente lugar e data do último crime para que o detetive compareça. É ele o alvo. Scarlach não partilha essa paixão geométrica da sua vítima. $L a$ muerte y la brújula é, mais que um policial de enigma, um comentário paródico sobre as possibilidades do subgênero na Argentina, lá pela metade do século XX, sublinhando a sua "irrealidade", sua falta de verossimilhança nessas latitudes. Para o autor de Pierre Ménard, autor del Quijote, e pensando no discurso do Ingenioso Hidalgo sobre as armas e as letras, não há ingenuidade possível. Ao contrário, o erro de confundir o mundo real com a literatura é o tema do conto e a confusão de Lönnrot é o motor que movimenta o enredo.

Red Scarlach é judeu, conhece a tradição. Sabe a quantidade de letras do nome secreto de deus. Também sabe que Lönnrot, aquele que pôs o irmão de Red na cadeia, obsessivo como é, não deixará de descobrir que o 
nome de deus, na tradição judaica, tem quatro letras. Deixa três pistas, correspondentes aos três primeiros assassinatos, que acontecem em pontos geográficos eqüidistantes, como os vértices de um triângulo eqüilátero. Qualquer um suporia que a série acabou com o terceiro assassinato, mas não Erik Lönnrot. O assassino, o pleonástico Red Scarlach, deixa uma redundância de pistas, às quais só Lönnrot pode prestar atenção: o desenho repetido do losango. Os artigos do jornalista dão ao assassino a confirmação da leitura que Lönnrot faz das pistas. Só ele está convencido de que a série de assassinatos, que aconteceram com intervalo exato de um mês, se completará com o quarto. No mapa, o triângulo eqüilátero tem seus vértices ao Leste, ao Oeste e ao Norte. Para completar o losango, traça os segmentos que se interceptam num vértice ao Sul. O primeiro crime aconteceu no dia 3 de dezembro e os dois seguintes no dia 3 dos meses seguintes. Para qualquer um essa pista redundante confirmaria que o terceiro crime é o último. Não é assim para Lönnrot. Ele investiga a tradição judaica e sabe que nela o dia começa com o por do sol. Isto é, o dia 3 do mês, é na suposta contagem judaica, o dia 4. Lönnrot dirige-se ao local exato do vértice Sul do losango, ao por do sol do dia 3 de março. Lá encontra uma construção simétrica, redundante, assim como o losango, assim como o próprio nome pleonástico de Red Scarlach. E assim Lönnrot é emboscado e morto.

A brincadeira geométrica do conto é um jogo de esconde-esconde do assassino com o investigador e também do autor com o leitor. Quem se vê surpreendido pela armadilha é justamente aquele que aposta na perfeição matemática do modelo que, porém, não pela sua beleza, é verdadeiro dentro 
do enredo. O conto não é, portanto, uma exaltação da beleza geométrica do policial de enigma, e sim um comentário que nega sua eficácia para dar conta da realidade.

A descrição do espaço remete permanentemente a Buenos Aires dos anos 40 e os seus subúrbios, sem mencioná-los em momento algum. A referência ao rio, ao Leste, e aos bairros onde acontecem as mortes não deixam dúvidas. Também é significativa a multiplicidade de tipos humanos que configura o aluvião migratório que se somou aos criollos na primeira metade do século $X X$ na cidade:

El primer crimen ocurrió en el Hotel du Nord -ese alto prisma que domina el estuario cuyas aguas tienen el color del desierto.(p. 154)

El segundo crimen ocurrió la noche del 3 de enero, en el más desamparado y vacío de los huecos suburbios occidentales da la capital. Hacia el amanecer, uno de los gendarmes que vigilan a caballo esas soledades vio en el umbral de una antigua pinturería un hombre emponchado, yacente.(p. 158)

[...] Treviranus indagó que le habían hablado desde Liverpool House, taberna de la Rue de Toulon -esa calle salobre en la que conviven el cosmorama y la lechería, el burdel y los vendedores de biblias. Treviranus habló con el patrón. Este (Black Finnegan, antiguo criminal irlandés, abrumado y casi anulado por la decencia)- le dijo que la última persona que había empleado el teléfono de la casa era un inquilino, un tal Gryphius, que acababa de salir con unos amigos. (p. 159-160)

El tren paró en una silenciosa estación de cargas. [...] Vio perros, vio un furgón en una vía muerta, vio el horizonte, vio un caballo plateado que bebía el agua crapulosa de un charco.(p. 165)

La muerte y la brújula como também La historia universal de la infâmia, do mesmo autor, correspondem a um esforço, próprio das vanguardas latinoamericanas, para acriollar subgêneros, procedimentos literários, surgidos em outras latitudes. 
Penso que La muerte y la brújula é influência fundamental para as primeiras ficções policiais de Walsh. Também ele participava do esforço para acriollar o subgênero. Acriollar, neste caso, é também testar quais são seus limites para a verossimilhança, seus limites como modelo explicativo da realidade. Parece que foram essa intenção e as frustrações que o policial de enigma provocou em Walsh que o levaram a passar do fair-play ao hardboiled, primero, e ao abandono da literatura policial, depois.

Na exploração do policial de enigma, já em Las tres noches de Isaías Bloom, Walsh constrói personagens e os coloca num cenário tipicamente portenho. As vozes e os cenários "prefiguram" o Walsh de La máquina del bien y del mal ou Corso, com seus registros de voz, seus ambientes e seus personagens marginais. O já citado Romano atribuía a filiação desse naturalismo na captura da linguagem coloquial/marginal à literatura de costumes de Barletta. Mas esse tratamento das vozes dos personagens do conto de Walsh também pode ser creditado a uma filiação arltiana. É o lunfardo presente, por exemplo, em Los siete locos.

- Pero, decime, ¿vos no podés prestarme esos seiscientos pesos?

El otro movió lentamente la cabeza:

- ¿Te pensás que porque leo la Biblia soy un otario?

Erdosain lo miró desesperado:

- Te juro que los debo.

De pronto ocurrió algo inesperado.

El farmacéutico se levantó, extendió el brazo y haciendo chasquear la yema de los dedos, exclamó ante el mozo del café que miraba asombrado la escena:

- Rajá, turrito, rajá. 
Erdosain, rojo de vergüenza, se alejó. Cuando en la esquina volvió la cabeza, vió que Ergueta movía los brazos hablando con el camarero. ${ }^{10}$

Essa filiação arltiana, assim como a borgeana, parece ser consciente e intencional. Em diálogo com Francisco Urondo, Mario Benedetti e Juan Carlos Portantiero, em 1969, Walsh apresenta a literatura argentina como um campo de forças com dois pólos: Borges e Arlt:

Arlt forma uno de los dos polos válidos, válidos hasta el día de hoy para cualquier narrador argentino. El otro polo es Borges. Ellos polarizan las dos tendencias, las dos actitudes de la lucha de clases en un poeta. ${ }^{11}$

Além das vozes, a escolha do cenário de pensão em Las tres noches de Isaías Bloom, assim como no posterior Nota al pie, é também um indício da filiação arltiana. A pensão, ao contrário do cortiço, é morada de seres desgarrados, solitários. O cortiço, por sua vez, cenário privilegiado da literatura de costumes proto-peronista, reúne famílias que lutam pela ascensão social coletiva. A sociabilidade do cortiço aparece no teatro de costumes de Discépolo ${ }^{12}$ e de Vacarezza ${ }^{13}$, que produziram suas obras na época prévia e durante o primeiro governo peronista, coincidindo com a grande onda de industrialização, num período de pleno emprego.

$\mathrm{Na}$ pensão, a falta de referências conduz primeiro ao delírio e ao

10 ARLT, Roberto. Los siete locos. 13a . Edição. Buenos Aires: Losada, 1997, p. 19.

11 PORTANTIERO, Juan Carlos; URONDO, Francisco e WALSH, Rodolfo. "La literatura argentina del siglo XX". In: BASCHETTI, Roberto (org.). Rodolfo Walsh, vivo. Buenos Aires: de la Flor, 1994, p. 33-61.

12 Ver, por exemplo, DISCÉPOLO, Armando."Mustafá". In: Revista Teatral. Buenos Aires: $1921,3-40$.

13 Ver, por exemplo, VACAREZZA, Alberto. El conventillo de la Paloma. Buenos Aires. Ediciones del Carro de Tespis. 1965. 
afrouxamento dos valores morais, depois à loucura e ao crime. A construção desse espaço está presente em Los siete locos e nas Aguafuertes porteñas de Arlt e também em obras de outros autores, como o romance Camas desde un peso, de Enrique González Tuñón. E essa associação permaneceu como um substrato latente de significados, recuperada na literatura posterior a 1955, quando as mudanças na legislação trabalhista e o crescimento do desemprego provocaram uma desagregação social e novas ondas de migração interna, sempre configurando um ambiente de incomunicação e pobreza, povoado de personagens desenraizadas.

A dupla genealogia presente nesse relato inaugural de Walsh sintetiza os esforços para acriollar o policial. Mas o autor não se limita a repensar o que Arlt e Borges fizeram com aquela literatura que precisava ser traduzida. Walsh bebe diretamente nas fontes. Ele as conhece profundamente: dedicouse a traduzi-la para o espanhol ${ }^{14}$.

Voltemos a Las tres noches de Isaías Bloom. Como em La muerte y la brújula, mas também como na obra de Conan Doyle, há uma dupla que desvenda o mistério. Porém, nos dois contos, de Walsh e de Borges, a dupla é formada por um delegado de polícia e por um jornalista da seção policial. No caso de Las tres noches de Isaías Bloom, o jornalista, Suárez, é antes um rascunho malandro do que depois será Daniel Hernández ${ }^{15}$. Suárez e o delegado, ao contrário de Lönnrot e Treviranus do conto de Borges, decifram

14 Walsh traduziu obras de William Irish, Ellery Queen, Cornell Wolrich, Evelyn Piper, Victor Canning, Norman Berrow, Ambrose Bierce, John Dickson Carr, Adrian e Arthur Conan Doyle, George Simenon, Edgar Alan Poe, Raymond Chandler, entre outros.

$15 \quad$ Alter ego do autor nas narrativas policiais posteriores. 
o enigma simultaneamente. A presença da dupla justifica o diálogo e evita o monólogo interior. Ambos são malandros, ninguém é virtuoso, a tensão é aquela que existe entre as instituições que cada um representa.

Tanto no conto de Borges quanto no de Walsh, o crime se configura, como projeto e como registro, na semivigília de nove e de três noites de sonho interrompido, respectivamente. Em La muerte y la brújula, o projeto é inspirado pelo discurso de um irlandês que pretendia converter Red Scarlach à fé dos góim, durante nove noites de delírio febril do segundo. Em Las tres noches de Isaías Bloom, os indícios que, decifrados, permitem descobrir o assassino estão plasmados no sonho de um homem com nome de profeta e sobrenome irlandês, como o de Walsh. O autor assinará depois muitos dos seus escritos com o pseudônimo de Daniel Hernández. Daniel é outro profeta, o que decifra sinais e produz julgamentos. Só que o alter ego de Rodolfo Walsh é um profeta Daniel acriollado: como (José) Hernández, o autor do Martín Fierro. Daniel Hernández aparecerá depois também como personagem nas suas ficções policiais, tirando para sempre o lugar de Suárez, e o seu colega de dupla deixará também de ser um delegado malandro.

No enredo, Isaías Bloom é estudante de medicina e mora num quarto de pensão que partilhava com a vítima de um assassinato. Nas duas noites que antecederam à do crime, Isaías sonhou. Ele toma nota dos seus sonhos, porque está estudando psicanálise e quer refletir sobre eles. Na primeira noite sonhou com um bosque e uma borboleta de luz que revoava entre as 
árvores e que ele tentava pegar. Então sentiu um barulho metálico, acordou e ficou olhando para a esfera do relógio despertador acima da escrivaninha. De repente, não mais a enxergava e logo voltou a vê-la. Na segunda noite, sonhou que ia por uma rua escura e viu cair uma taça que quebrou e desapareceu deixando no pavimento uma poça de água verde com forma de estrela. Depois, ele comprava um jornal com a manchete: "Se ha extraviado una copa que responde a la nota Sol”"16. A dupla de investigadores tinha percorrido a pensão, observado o espaço e interrogado os moradores dos outros quartos. Amarram fios soltos: a borboleta iluminada podia ser uma lanterna e a desaparição momentânea da esfera do relógio podia ser alguém que entrou no quarto e passava na frente dela; a taça podia ter quebrado mesmo, quando o criminoso quis colocar nela veneno, e podia ter sido embrulhada no tapete verde que foi substituído por outro que faltava no quarto do assassino, para não deixar traços do líquido. Na noite seguinte, quando Isaías Bloom estava de plantão no hospital, o assassino consumou o crime com uma faca.

O sonho interpretado também evoca o bíblico José. Só que os indícios nele presentes não são sinais de Deus. Os sonhos de Isaías Bloom são vistos como tentativas de não interromper o sono, incluindo os estímulos exteriores na narrativa onírica. O relato onírico aparecerá depois em El soñador e na Carta a Vicky: no primeiro caso, como história subjacente que termina se impondo sobre a outra que corre na superfície do conto; na Carta a Vicky, encapsulando o núcleo traumático do relato, núcleo indizível pelo

16 WALSH, Rodolfo. "Las tres noches de Isaías Bloom". In: Cuentos para tahúres y otros relatos policiales. 3ª . Edição. Buenos Aires: de la Flor, 1999, p. 78. 
próprio autor/testemunha de sua dor pela morte da filha. Nessa carta, Walsh, assim como Isaías Bloom, é o que percebe os sinais. Não pode interpretar. Comunica-os para que outros o ajudem a entender, a outros que, como o delegado de Las tres noches de Isaías Bloom, aconselhem: "Seguí soñando, pibe.“17, com esse inconfundível sotaque portenho.

Neste primeiro relato policial, a posição do autor em relação à violência policial é muito diferente daquela postura crítica que assumirá depois, em Operación Masacre e La secta del gatillo alegre. Censurando dois estudantes hospedados na pensão, o delegado diz: "Pero si usted los mira fijo, le dicen torturador“'18. O autor percorrerá ainda um longo caminho que o distanciará desta perspectiva.

\section{La aventura de las pruebas de imprenta.}

\section{A imersão nas fontes}

Depois dessa primeira incursão, Walsh publica, em 1953, uma coletânea chamada Variaciones en rojo, com três novelas policiais: La aventura de las pruebas de imprenta, Variaciones en rojo, que dá o título à edição, e Asesinato a distancia. Também publica uma nota sobre Conan Doyle na revista Leoplán e traduz La aventura de los jugadores de cera e La aventura de los siete relojes e outros contos de Adrian Conan Doyle em colaboração com Dickson Carr entre 1953 e 1954. As referências à literatura

17 WALSH, Rodolfo. "Las tres noches de Isaías Bloom". In: Cuentos para tahúres y otros relatos policiales. Ed. cit., p. 83.

18 WALSH, Rodolfo. "Las tres noches de Isaías Bloom". In: Cuentos para tahúres y otros relatos policiales. Ed. cit., p. 73 . 
dos Conan Doyle são explícitas. Variaciones en rojo, já pelo título é uma homenagem a Um estudo em vermelho. No centro das narrativas La aventura de las pruebas de imprenta e $A$ aventura dos três estudantes de Conan Doyle, estão as provas de gráfica.

No enredo de $A$ aventura dos três estudantes, o detetive Sherlock Holmes recebe a visita do professor do Colégio St. Luke. Ele havia preparado uma prova de Grego Antigo para o concurso que daria acesso a uma avultada bolsa de estudos e que seria realizado no dia seguinte. Alguém tinha mexido nos papéis do professor, a porta da sua sala havia sido aberta e uma chave tinha sido deixada na fechadura. Além das três folhas amarrotadas e fora de lugar, o intruso tinha deixado lascas de lápis recém apontado. Nelas apareciam em cor prateada as letras "NN", como as da marca "Johann Faber". O lápis não é comum na Inglaterra. Não havia qualquer impressão digital nos papéis ou pegadas no chão, mas o dia era seco. Um suspeito é Bannister, o criado do professor; ele esqueceu a chave ao ir retirar a bandeja de chá. Outro é um estudante indiano, com dificuldades em Grego Antigo, que entrou depois da descoberta do professor, perguntando por detalhes da prova. Mais dois estudantes moravam em apartamentos cuja escada passava pela porta do professor: um, de uma família rica depois empobrecida da Rodésia, estudante esforçado, e, por fim, um estudante brilhante, mas vadio. Bannister, descobre Holmes, foi criado do pai do estudante da Rodésia. O detetive interroga ambos e tudo se esclarece.

O enredo de La aventura de las pruebas de imprenta gira em torno da 
morte de Raimundo Morel, um revisor, tradutor e escritor. Um olhar superficial faria julgar que se trata de um suicídio ou um acidente, já que Morel estava sozinho no estúdio da sua casa, sentado com as provas de gráfica de um texto que devia entregar com urgência e com uma arma da sua propriedade, assim como os acessórios necessários para a limpeza da arma, acima da mesa. O delegado Jiménez encaminha a análise de balística ao perito enquanto Daniel Hernández, um revisor, colega de Morel, presta atenção às provas de gráfica que o morto estava revisando. A caligrafia de Morel se torna vacilante, quase um garrancho, para voltar ao normal no trecho seguinte e imediatamente decair novamente. A intermitência desse registro não permite diagnosticar uma bebedeira e configura o único elemento que não encaixa numa explicação de suicídio ou acidente. Depois de reunir as informações sobre a localização da casa de um suspeito, amigo da família, e os horários nos quais Morel foi visto e o seu cadáver descoberto pela esposa que retornava ao lar, Daniel Hernández constrói uma outra hipótese. O seu conhecimento do ofício de revisor permite que imagine uma viagem de trem para o subúrbio onde mora o suspeito. A vítima pode ter se deslocado com as provas, já que tinha urgência em entregá-las, com o intuito de trabalhar nelas durante o trajeto. A intermitência na caligrafia vacilante podia corresponder à freqüência das estações nas que o trem se detém. Uma tabela de horários de trem e as provas de gráfica permitem imaginar procedimentos, motivações, movimentos da vítima e dos cúmplices no crime, a mulher e o seu amante, amigo da família e executor, para receber o seguro de vida do morto.

A palavra "provas" tem vários sentidos: em ambas narrativas trata-se, 
além de provas de gráfica, de indícios ou provas do delito; no relato de Conan Doyle, também se trata de uma prova escolar. Mas, nos dois enredos, as provas referem-se a traduções: do inglês, de um livro de Oliver Wendell Holmes, autor homônimo do personagem de Conan Doyle, na novela de Walsh; de Grego Antigo, em A aventura dos três estudantes.

Nessa coletânea se afirma uma nova dupla: o delegado Jiménez e Daniel Hernández. Walsh parece voltar ao policial de enigma "a la" inglesa: o par é expoente do bom-mocismo e desaparece a voz plebéia presente em Las tres noches de Isaías Bloom, como se o autor fizesse um exercício para dominar os tiques originais do subgênero, filtrados no conto pelas leituras de Borges.

Em La aventura de las pruebas de imprenta, a dupla é formada por um expoente da "polícia científica", o delegado Jiménez, e Daniel Hernández, cujo conhecimento baseia-se no domínio de um ofício, o de corretor de provas de gráfica, que compartilha com a vítima. Esse foi, durante anos, também, o ofício de Walsh. E são esses saberes de pobre, presentes em toda a literatura do autor, nos seus contos e em não poucas reportagens para revistas $^{19}$, os que permitem desvendar o crime. Há um diálogo, um embate, entre o conhecimento da ciência e o conhecimento do ofício, no qual ambos medem a sua eficácia. O fato de o assassino nada saber desse ofício impede-lhe apagar os rastros, os indícios, a informação encriptada no registro

19 Ver, por exemplo, a série de reportagens sobre diferentes ofícios, republicados por Daniel Link:WALSH, Rodolfo. "La Argentina ya no toma mate"; "Kimonos en la tierra roja"; "EI matadero"; "Las carnes que salen del frío" e "Magos de agua dulce". In: LINK, Daniel (org.). Rodolfo Walsh. El violento oficio de escribir. Obra periodística 1953-1977. 2ª . Edição. Buenos 
das correções, que só Daniel Hernández pode reconhecer e interpretar. O corretor/detetive amador decifra uma escrita incompreensível. Só um corretor de ofício, que sabe ler com "lentidão", pode compreender:

[...] Entonces, ¿para qué sirve la experiencia? Para leer despacio - respondió Daniel $[\ldots]^{20}$

Ler com lentidão para apanhar os sinais é a capacidade que Walsh cultivará para alimentar seu ofício de criptógrafo. É a qualidade que permeia sua trilogia de investigação e o seu trabalho jornalístico. Acompanhará o autor, também como tema obsessivo, na sua obra. A epígrafe do relato que temos em mãos foi extraída do Livro de Daniel. Daniel, o que foi jogado na cova dos leões. Seu nome está associado à capacidade de julgamento: aquele que pode "declarar las dudas y desatar dificultades [...] leer [la] escritura y mostrar [...] su explicación [...]"21. Não desdenhemos o conhecimento bíblico de Walsh, o irlandês.

Segundo a comparação de Eduardo Romano entre as duplas Treviranus/Lönnrot, de Borges, e Jiménez/Hernández, de Walsh, se Treviranus e Jiménez primam pelo profissionalismo, o primeiro age de maneira rotineira enquanto o segundo pretende aplicar sistematicamente os conhecimentos científicos; já, se Lönnrot peca por excesso de literatura,

Aires: Planeta, 1998, p. 122-130; p. 131-134; 144-149; p. 150-156 e p. 157-161.

20 WALSH, Rodolfo. "La aventura de las pruebas de imprenta". In: Obra literaria completa. ${ }^{2}$. Edição. México: Siglo Veintiuno, 1985, p. 55. Neste capítulo, as referências a "La aventura de las pruebas de imprenta" que aparecem a seguir indicam as páginas desta edição.

21 DANIEL 5:16 apud: WALSH, Rodolfo. "La aventura de las pruebas de imprenta". In: Obra literaria completa. Ed. Cit, p.11. 
Hernández questiona o conhecimento literário, o cânone, como um entorpecente que impede a vítima de perceber a cilada em que caíra, dizendo que esta vítima era cega a tudo que não fosse sua vocação de escritor.

Isto faz pensar que o embate entre ciência e ofício, na obra de Walsh, não se faz necessariamente sobre uma relação de antagonismo. Mais do que tensão entre Jiménez e Hernández, há colaboração e ajuste: o conhecimento científico deve se completar com outro mais prático.

Em 1957, Walsh traduzirá La historia del FBI. E publicará na revista Leoplán ${ }^{22}$ uma nota promovendo o livro: Los métodos del FBI. Nela, valoriza os métodos científicos da agência dos Estados Unidos. A data desta nota coincide com a primeira publicação de Operación Masacre, obra que traz à tona a truculência da polícia argentina. Talvez nessa nota se explicitem as idéias do autor sobre o que seria um bom desempenho policial, também presentes na colaboração entre o delegado e o corretor das provas da narrativa em questão.

Os métodos de investigação de Jiménez e de Hernández complementam-se como acontece nos diálogos entre Holmes e Watson. O próprio Hernández comenta suas hipóteses com um colega, chamando-o de "Watson", na brincadeira (p. 15). Em outra passagem torna explícita a coincidência entre o personagem de Conan Doyle e o autor que a vítima

22 A editora do livro, Sopena, também é dona da revista Leoplán. 
estava traduzindo:

Holmes - musitó Daniel con expresión extraviada - Oliver Wendell Holmes. Sherlok Holmes. Extraña coincidencia... ¿Recuerda usted el curioso incidente del perro?

Rodríguez lo miró como si empezara a creer que se había vuelto loco.

¿Ha olvidado los clásicos? Insistió Daniel - El curioso incidente del perro era que no había ladrado de noche. (p. 35)

O indício do cachorro que não latiu em Um estudo em vermelho é, no caso de La aventura de las pruebas de imprenta, os garranchos que aparecem com uma freqüência regular nas correções de prova gráfica e que indicariam uma improvável "bebedeira intermitente". Só Daniel pode interpretar esse indício: é o que acontece quando o corretor que tem de entregar o trabalho num prazo curto corrige num trem sem se deter quando ele entra em movimento.

Há, no entanto, uma outra tensão, apontada, como indicado acima, por Eduardo Romano. A diferença entre Lönnrot e Daniel Hernández permite vislumbrar uma distância entre Walsh e o grupo da revista Sur, do qual Jorge Luis Borges e Adolfo Bioy Casares participavam. Borges faz sucumbir a poética de Lönnrot nas mãos do prosaico Red Scarlach. Lönnrot é vítima do destino, como um herói trágico, no mundo desencantado. Por outro lado, a vítima de La aventura de las pruebas de imprenta chama-se Raimundo Morel. Morel, como o personagem de Bioy Casares. O Morel de Casares, no relato estranho La invención de Morel, como o personagem do romance Museo de la novela de la Eterna, de Macedônio Fernández, cria uma máquina de narrar 
que substitui a realidade.

No enredo de La invención de Morel, um fugitivo escondeu-se em uma ilha supostamente deserta e, de repente, "habitada" por personagens que o ignoram completamente. Sem querer, ele acionou uma máquina que trouxe o registro de veranistas que alguma vez aportaram naquele lugar. Esse registro é holográfico, e "conta" uma e outra vez a saga dos personagens daquelas férias. O protagonista apaixona-se por Faustine, um desses "fantasmas", e demora a entender o que acontece.

O Morel de Walsh sucumbe por não prestar atenção à realidade, por não reconhecer a traição de seu amigo e a da sua esposa, por acreditar na ficção do amor conjugal, como uma deformação profissional do especialista em literatura. Assim parece pensar Daniel Hernández, num trecho em que quer amenizar a culpa da esposa de Morel:

No debemos criticarla demasiado. En cierto modo estaba defendiendo su derecho a la felicidad, un derecho que Morel, ciego a todo lo que no fuera su vocación de escritor, había descuidado. (p. 65)

Em La aventura de las pruebas de imprenta, Walsh também compara a honestidade dos leitores com a ausência desta entre os escritores:

Aún no son las cinco de la tarde. Dentro de un rato habrá un hervor de gente que entra y sale. Vendrá el poeta que acaba de "publicar", para preguntar si "sale" su libro. Los vendedores lo conocen, conocen el gesto ambiguo que no quiere desalentar, pero tampoco infundir excesivas esperanzas. Vendrá el autor desconocido que ha escrito una novela de genio, y quiere a toda costa que esta editorial -y no otra- sea la primera en publicarla. Si insiste, si se muestra irreductible, algún vendedor lo mandará al tercer piso, donde está la 
sección Ediciones. El manuscrito permanecerá dos o tres semanas en un cajón, hasta que al fin un empleado leerá las primeras veinte páginas, por simple tranquilidad de conciencia, y lo devolverá con una nota cortés, explicando que "por el corriente año está completo nuestro plan de ediciones". Vendrá la ex secretaria de Mussolini, del rey Faruk o del Mahatma Gandhi, que quiere publicar sus memorias, pues las considera de sumo interés para resolver la situación mundial. Y también -por qué no- vendrán algunos honestos clientes, que sólo desean comprar un libro. (p. 11-12)

A propósito disto, Eduardo Romano escreve:

[...] sintomatiza ciertas contradicciones que Walsh trataba entonces de asumir entre su participación en la industria cultural de la época y los juicios despectivos al respecto que predominaban entre intelectuales. No es ciertamente casual que haya referencias de ese carácter en los tres relatos de "Variaciones en rojo". ${ }^{23}$

Apesar disto, a idéia da máquina de narrar voltará com La máquina del bien y del mal, a ser examinada no terceiro capítulo, e que é uma reflexão sobre a possibilidade de criar uma máquina que se opõe à literatura consagrada e às narrativas de Estado. Uma máquina construída em oficinas de fundo de quintal, com procedimentos plebeus, com conhecimentos que provêm dos saberes de pobre e que permitem construir uma contra-história.

Até para lutar contra a herança borgeana, Walsh apropria-se de muitos dos seus temas e procedimentos, como o de dotar os paratextos de sentido ficcional, como faz Borges em, por exemplo, La casa de Asterión. Walsh levará esses procedimentos ao limite, como no caso extremo do conto Nota al pie. Também aproveita esse recurso em La aventura de las pruebas de imprenta, ilustrando a narrativa com a tabela de horários de trem e com o facsímile das provas de gráfica.

23 ROMANO, Eduardo. "Modelos, géneros y medios en la iniciación literaria de Rodolfo J. Walsh". In: LAFFORGUE, Jorge et ALL. Textos de y sobre Rodolfo Walsh. Ed. cit., p. 85. 
Já nesta coletânea, que depois 0 autor dirá detestar, prefigura-se o Walsh jornalista, aquele da trilogia de investigação. Na coletânea estão presentes aquelas marcas que serão características atribuídas por Ferro ao rigor investigativo do escritor ${ }^{24}$ : a enumeração de provas, a consolidação de hipóteses, a utilização de fac-símiles e tabelas e, no caso de Variaciones en rojo e Asesinato a distancia, o croquis.

Além de Las tres noches de Isaías Bloom e desta coletânea, Walsh escreve a novela La sombra de un pájaro, publicada pela primeira vez na revista Leoplán em 1954 e o conto Tres portugueses bajo un paraguas (Sin contar el muerto) que podemos enquadrar no subgênero do policial de enigma. Mas já em Asesinato a distancia, pertencente à coletânea, Daniel Hernández abandona o fair-play e se expõe a riscos para desvendar o crime, riscos antecedentes daqueles que correrá o nosso "Quixote", ao investigar o massacre de José León Suárez para produzir Operación Masacre.

\section{Zugwang. Transposición de jugadas. En defensa propia.}

Um ponto de inflexão: do policial de enigma ao hard-boiled

Em junho de 1956, dois acontecimentos abalam a atividade literária de Walsh. Um é bem conhecido: as escaramuças ao redor da sua casa no dia 9 de junho, durante o putch cívico-militar liderado pelos generais Valle e Tanco, para reconduzir Juan Domingo Perón, presidente deposto no ano anterior por

24 FERRO, Roberto. "Prólogo". In: WALSH, Rodolfo. Caso Satanowsky. Buenos Aires: de la Flor, 1997, p. 7-14. 
um golpe militar, ao poder. Meses depois, descobre que nessa mesma noite houve fuzilamentos ilegais de civis num lixão da periferia por parte das forças policiais. O putch surpreende Walsh enquanto jogava xadrez no clube. $O$ outro acontecimento não tem sido estudado: trata-se da leitura, tradução e condensação de uma novela de espionagem, única obra literária de Sir Duff Cooper, Operation Heartbreak, tradução que tinha sido encomendada a Walsh pela revista Leoplán. No segundo capítulo, tratarei mais detalhadamente dos dois acontecimentos, analisarei e descreverei a forma em que eles atingiram o nosso autor, mas preciso registrar aqui o efeito que o primeiro teve para a transformação da literatura policial do escritor.

Em ambos os casos, o Estado gerava sentidos pelo recurso à narrativa. Transformava seres anônimos, plebeus, em heróis ou vilãos. Walsh inicia uma investigação jornalística que, aos poucos, colocará sua vida em risco. Trata-se de um crime de Estado. Um Estado e um governo que até então Walsh tinha apoiado. No começo, ele julga tratar-se de uma ação da polícia provincial, fora do controle central, mas a própria investigação o leva a mudar seu julgamento. As suas certezas ficam abaladas. $\mathrm{O}$ modelo do policial de enigma, que supõe o bom-mocismo dos policiais e a maldade dos bandidos, já não serve para dar conta dessa realidade que ele descobre mais complexa.

Ainda em novembro de 1956, antes de iniciar as investigações, publica Simbiosis. Nesse conto e nos seguintes Zugzwang, Transposición de jugadas e em En defensa propia a dupla muda. Daniel Hernández permanece, mas já 
não é ele quem desvenda os crimes. O delegado já não é Jiménez e sim Laurenzi. O policial tampouco "desvenda" o crime. Apenas narra seu próprio fracasso em desvendá-lo em tempo, em encontrar os culpados, em levá-los para julgamento, em discernir onde está o bem e onde está o mal. Laurenzi, já aposentado, conta seu fracasso em narrativa emoldurada em uma conversa de café, enquanto joga xadrez com Daniel. A geometria precisa do xadrez contrasta com a indefinição que colore o enredo.

É também daquele período um pequeno texto ensaístico de Walsh chamado Claroscuro del subibaja no qual se explicita esse estado de espírito. No texto, o autor narrativiza o surgimento das palavras por meio de uma espécie de mito chinês, segundo o qual antes as palavras eram menos maniqueístas. Para dar o conceito de distância, por exemplo, usava-se uma palavra composta que poderia ser traduzida como perto-longe. Um termo que, segundo o autor, daria conta com maior eficácia de uma realidade que é necessariamente contraditória.

Zugzwang foi publicado pela primeira vez em dezembro de 1957, na revista Vea y Lea. Walsh utilizou nele o formato da narrativa emoldurada, como tinha feito em Operación desengaño, adaptação de Operation Heartbreak para a revista Leoplán, para respeitar o formato da obra de Duff Cooper, em junho do ano anterior. Já em Simbiosis, conto publicado pela primeira vez em novembro de 1956, também tinha utilizado o procedimento, mas é em Zugzwang que aperfeiçoou o recurso, explicitando se tratar de uma conversa de café entre Daniel Hernández e o delegado Laurenzi. Não é um 
café como os outros: ele reúne jogadores de xadrez e até os garçons comentam as jogadas, dão palpites e brincam com os fregueses com uma certa cumplicidade a propósito do métier. O diálogo não é um simples recurso para comentar a história que Laurenzi relata. O enredo desloca-se no mesmo espaço do café, situações repetem-se em dois jogos de xadrez, no presente e no passado. Mas a posição de zugzwang -situação em que um jogador de xadrez não pode fazer qualquer jogada vantajosa: qualquer movimento de peça o faz perder - desses jogos repete-se também na vida de dois personagens: do protagonista da narrativa de Laurenzi e dele próprio. Esse relato em vários planos parece ilustrar uma idéia presente em um outro texto de Walsh publicado pela primeira vez em 1953, na revista Fénix: El ajedrez y los dioses. Segundo o texto, os deuses não jogariam sobre um tabuleiro, e sim em um cubo com quinhentas e doze casas cúbicas. O deslocamento das peças aconteceria assim em mais de duas dimensões.

O relato de Laurenzi vem à tona durante um jogo com Hernández, no qual Laurenzi cai numa posição de zugzwang. Aparentemente, a situação evoca um outro jogo, de Aguirre, um antigo freqüentador do café, já falecido. E o recurso da narrativa emoldurada parece, num primeiro momento, uma simples desculpa para rememorar a história desse jogador.

Aguirre, um homem de 60 anos, jogava por correspondência com membros da federação internacional de xadrez, assim como Laurenzi. Num jogo com Finn Redwolf, um velho escocês de Glasgow, também havia caído na posição de zugzwang. Mas também tinha descoberto que Redwolf era 
aquele que havia seduzido a sua mulher e a havia abandonado, provocando o suicídio desta. O próprio adversário foi entregando as informações misturadas com as conversas sobre o jogo, sem saber da relação entre Aguirre e a falecida, contando vantagens a propósito das suas numerosas viagens e, em particular, a que tinha feito muitos anos atrás para Argentina. Redwolf ia se revelando como uma personalidade cruel. Aguirre, então, viajou a Glasgow e ali o matou.

Laurenzi narra a história para Hernández, seguindo a ordem cronológica em que foi conhecendo os detalhes e se aproximando de Aguirre, chegando a visitá-lo no seu quarto, no hotel onde morava. Recupera as sensações e os sentimentos que as revelações do amigo provocavam, tecendo nas confidências a solidariedade entre o protagonista, Aguirre, e o testemunha, Laurenzi.

O sentimento de solidariedade veio à tona também na trajetória do próprio Walsh, quando a investigação que resultaria em Operación Masacre o colocou em contato com sobreviventes do fuzilamento de José León Suárez. Esse contato viria abalar as suas certezas a propósito do lugar do bem e o do mal. A dúvida talvez esteja já em uma suspeita apresentada pelo autor em 1953, em El ajedrez y los dioses:

Se ha dicho pobremente que las fuerzas de un bando simbolizan el bien; las otras el mal. Cualquiera puede comprobar la estúpida mentira de esa creencia. Los dioses no tienen idea del bien y del mal. De lo contrario no podrían existir. En el preciso instante en que la sola idea del bien o del mal entrar furtivamente en la voluntad que mueve las piezas sobre el tablero, éste saltaría en pedazos 
como una gigantesca copa de cristal. ${ }^{25}$

Para Laurenzi, como para Walsh, abalam-se as certezas a propósito de onde está o bem e onde está o mal. Qualquer jogada pode ser ruim. Por isso, Laurenzi não denuncia o assassinato cometido por Aguirre, justificandose por sua condição de aposentado, e pelo fato de o assassinato ter acontecido fora da sua jurisdição.

Transposición de jugadas foi publicado pela primeira vez em Vea y Lea em setembro de 1961. Também é uma narrativa emoldurada numa conversa de café entre Laurenzi e Hernández, em meio de um jogo de xadrez. Também, como em Zugzwang, uma jogada evoca um caso do delegado Laurenzi. Mesmo tendo um tom mais leve que Zugzwang, com alguns toques de humor, o problema é semelhante. Laurenzi não mais pode utilizar um instrumental lógico, cartesiano, para evitar o crime. Desta vez, o problema lógico é o ilustrado com o do lobo, a cabra e o repolho, no qual um barqueiro precisa transportar de uma margem para a outra de um rio, um por vez, os três sem que um abocanhe o outro. A solução é levar primeiro a cabra, sem risco do lobo comer o repolho. Depois buscar o lobo, deixá-lo na outra margem e levar a cabra de volta. Deixar a cabra e carregar o repolho para o destino dos três. E por último buscar a cabra para realizar junto com ela a última travessia. O trabalho é realizado, assim, em número mínimo de viagens.

25 WALSH, Rodolfo. "El ajedrez y los dioses“. In: LAFFORGUE, Jorge et ALL. Textos 
Esse modelo lógico tinha sido aplicado por Laurenzi em uma cidade pequena da Patagônia. Na cidade, o pai de uma jovem de dezessete anos, em começo de gravidez, atacara de espingarda na mão, o namorado da filha, que voltava de uma viagem de quatro meses. Assim, ameaçou-o de morte, caso não casasse com a moça. Laurenzi precisava levar os três para uma outra cidade, do outro lado do rio, para um juiz, um delegado e um padre resolverem a situação. Quando chegaram ao cais, a balsa estava quebrada, e só contavam com um barco pequeno no qual só podia viajar um por vez. Laurenzi temia que o pai atacasse o namorado da filha, e também temia que os dois jovens fugissem, sendo ela menor de idade. Não contava desse lado do rio com mais cela que a que podia improvisar na casa do balseiro, de apenas um ambiente. Levou primeiro o pai da moça, mas, chegando à outra margem percebeu que tinha errado. Deixou o homem e retornou remando furiosamente. $\mathrm{Na}$ casa do balseiro, o desastre estava feito. O jovem, sentindo-se traído durante sua ausência de quatro meses, estrangulou a moça. O problema, dizia Laurenzi, não era a aplicação da regra lógica, e sim saber quem era o lobo, quem era a cabra e quem era o repolho na história.

En defensa propia começa com a seguinte fala de do delegado Laurenzi, também dirigida a Daniel Hernández, no café:

- Yo, a lo último, no servía para comisario -dijo Laurenzi, tomando el café que se le había enfriado-. Estaba viendo las cosas, y no quería verlas. Los problemas en que se mete la gente, y la manera que tiene de resolverlos, y la forma en que yo los habría resuelto. Eso, sobre todo. Vea, es mejor poner los zapatos sobre el escritorio, como en el biógrafo, que las propias ideas. Yo notaba que me iba poniendo flojo, y era porque quería pensar, ponerme en el lugar de los demás, hacerme cargo, hasta que me jubilé. Una de

de y sobre Rodolfo Walsh. Buenos Aires: Alianza, 2000, p. 244. 
esas macanas es la que le voy a contar. ${ }^{26}$

Isto é, o relato será uma justificativa para o fracasso profissional do delegado, anunciado no primeiro parágrafo.

No enredo da narrativa emoldurada, Laurenzi recebe o telefonema de um juiz conhecido por sua integridade moral e rigoroso legalismo. O juiz Reynal avisa que acaba de matar um ladrão na sua casa. Quando o delegado chega, encontra Reynal sentado frente à sua escrivaninha, lendo, com o revólver apoiado sobre o tampo da mesa. Laurenzi vê o cadáver de Luzati, a quem o juiz diz não ter reconhecido. Reynal já o havia condenado em duas oportunidades por crimes diferentes: extorsão e tráfico de drogas. Luzati não era um assaltante. Laurenzi descobre um porta-retrato. Nele, a foto de uma moça. Trata-se de Alicia Reynal, filha do juiz, a quem o delegado tinha conhecido em outra jurisdição com o rosto mudado na foto do prontuário, no qual constava que era usuária de drogas. Logo entendeu o que tinha acontecido. Provavelmente, Luzati vinha extorquindo o juiz. Laurenzi retirou do bolso do morto a pistola que, sabia, este carregava, para evitar que aumentassem as suspeitas sobre Reynal, quem, o delegado imaginava, tinha atraído Luzati para uma emboscada. O envolvimento de Laurenzi favorecendo o criminoso não acontece sem tensões e velhas mágoas profissionais do policial que prende bandidos, logo soltos pelo juiz excessivamente legalista. Mas o lugar do bem já não aparece tão claramente

26 WALSH, Rodolfo. "En defensa propia". In: Cuentos para tahúres y otros relatos policiales. 3‥ Edição. Buenos Aires: de la Flor, 1999, p. 147. Neste capítulo, as referências a "En defensa propia" que aparecem a seguir indicam as páginas desta edição. 
localizável para o delegado.

Nos relatos policiais desta safra, o narrador não é mais em terceira pessoa, como nos da safra anterior. É Daniel Hernández em Zugzwang que narra: "Él [Laurenzi] sólo habla, yo escribo“27. O gesto de Hernández repete o do autor enquanto jornalista durante as suas reportagens de investigação, registrando o que as testemunhas the contam. Quase todos os contos policiais desse período abrem com uma fala do delegado Laurenzi. A exceção é Zugzwang.

Mantém-se o suspense e o jogo lógico, sublinhado em Transposición de jugadas pela referência ao velho problema do lobo, a cabra e o repolho; e em Zugzwang pela referência, já no título, a uma configuração possível no tabuleiro de xadrez. Mas alguma coisa se deteriora nessa certeza matemática para dar lugar à reflexão moral. Em Simbiosis, Laurenzi diz:

Lo que pasa es que uno también es un ser humano [...] con tres o cuatro palabras explicamos todo: un crimen, una violación o un suicidio. Vea, queremos que nos dejen tranquilos. ¡Pobre de usted si me trae un problema que no pueda resolverse en términos sencillos: dinero, odio, miedo! Yo no puedo tolerar, por ejemplo, que usted me salga matando a alguien sin un motivo razonable y concreto. ${ }^{28}$

A mudança é analisada por Pablo Alabarces da seguinte forma:

El giro que representa la aparición de Laurenzi sólo es posible después de "Operación...": Hernández pasa a ser interlocutor, es confinado al rol de escucha/mediador, narrador que anota los

27 WALSH, Rodolfo. "Zugzwang". In: LAFFORGUE, Jorge et ALL. Textos de y sobre Rodolfo Walsh. Buenos Aires: Alianza, 2000, p. 250.

28 WALSH, Rodolfo. "Simbiosis". In: Cuentos para tahúres y otros relatos policiales. 3a Edição. Buenos Aires: de la Flor, 1999, p. 103. 
relatos de Laurenzi. Y Laurenzi, para resolver sus muertes, pone en juego otra serie de saberes, ya no técnicos, sino "premodernos": olfateo, intuición, semblanteo. La cultura que Hernández representa sólo puede escuchar: sólo puede aprender. Hay una inversión de puntuación: el acento descansa sobre lo que Laurenzi evoca. En algunos momentos, incluso, la sapiencia de Hernández es ridicularizada por Laurenzi [.... ${ }^{29}$

A referência ao jogo de xadrez que corre paralelo aos relatos de Laurenzi esconde uma ironia. A posição "zugzwang", por exemplo, no conto homônimo, supõe um problema sem solução. O autor foi arrancado do jogo de xadrez na noite de 9 de junho de 1956. Naquela noite as certezas do jogador/jornalista se abalaram: ouviu, através das frestas da janela, a voz agonizante de um soldado que não morre gritando "Viva a patria!" e sim "no me dejen solo, hijos de puta"30. O soldado morreu defendendo um governo com o qual não tem identidade. Foram os rebeldes que permitiram ao jogador/jornalista chegar à sua casa. Meses depois descobre que o governo que ele defende realizou naquela noite fuzilamentos ilegais. É natural que se pergunte onde está a verdade.

Em 13 de junho de 1957, um ano e quatro dias depois daquela noite, três pistoleiros assassinam o advogado Marcos Satanowsky. Walsh reúne material que compromete membros de instituições de inteligência das forças armadas. Mas só o publica em 9 de junho de 1958, após a posse de um governo civil, o do presidente Arturo Frondizi, que foi eleito com acordos com o peronismo, que estava proscrito.

Há uma operação de imprensa, jogando uma cortina de fumaça para

29 ALABARCES, Pablo. "Dialogismos y géneros populares". In: LAFFORGUE, Jorge e outros. Textos de y sobre Rodolfo Walsh. Buenos Aires: Alianza, 2000, p. 29-38. 
esconder que os mandantes e os culpados são delinqüentes conhecidos. Walsh, como a dupla de Las tres noches de Isaías Bloom, não descarta os depoimentos dos marginais e, como aquela dupla, dirige-se a um dos pistoleiros numa carta aberta, usando o mesmo jargão marginal, apresentando as suas poucas possibilidades de sobrevivência se não entregar os mandantes.

O governo civil primeiro convida Walsh para colaborar com uma comissão parlamentar de inquérito. Quando ele e sua equipe começam a apresentar resultados, o governo, pressionado pelos militares, exige-Ihe guardar silêncio em nome do sigilo das investigações. Walsh filtra informação fragmentada, à maneira de isca. Por fim, quando o governo fecha as atividades da comissão e arquiva as investigações, o jornalista/detetive denuncia a cumplicidade do governo civil: publica a reportagem em forma de livro em 1959 -O caso Satanowsky.

Transposición de jugadas é publicado em 1961. Nele, e referindo-se ao problema do lobo, a cabra e o repolho, Laurenzi diz: “¿Cómo saber que una cabra no se portará como un lobo, o inclusive como una cabra?"31 Foi o dilema com que Walsh se encontrou para estimar a validade dos depoimentos dos marginais no caso Satanowsky, contrariando a desqualificação que a grande imprensa e o poder judiciário faziam desses testemunhos. Nesse conto, o jogo lógico demonstra a sua ineficácia: os seres humanos não são simples peças de tabuleiro. É preciso ter uma sabedoria 
fruto da experiência no trato com as pessoas.

Em En defensa propia abandona de vez o fair-play. É um policial hardboiled, subgênero que já se anunciava em Zugzwang. As leis são contornadas e as provas são ocultadas. A manipulação das regras depois aparecerá em Imaginaria. Como explica Laurenzi no começo, já citado, de En defensa propia: "[...] no servía para comisario [...]. Estaba viendo las cosas y no quería verlas“ (p. 98)

Laurenzi se aposenta e, de alguma maneira, aponta o destino do "autor de novelas policiales", como Walsh se definira em $1957^{32}$, em oposição a Borges, o "escritor". Walsh também aposenta o gênero e deplorará esses relatos anos depois. Mas é Trasposición de jugadas o conto no qual o fracasso do delegado é o tema, o motivo do conto. Ele não soube diagnosticar e por isso não soube evitar a desgraça.

\section{Do relato policial ao relato testemunhal}

As mudanças nas duplas de investigadores ao longo da literatura policial de Walsh sinalizam uma mudança na perspectiva do autor a propósito da história do país. Primeiro esboça-se uma quebra da confiança na aliança entre ciência e ofício para chegar à verdade, presente na colaboração entre Daniel Hernández e o delegado Jiménez, com ênfase no saber de ofício de Hernández, com recurso à investigação exaustiva que amarra todos os 
acontecimentos numa seqüência causal. Então, o narrador onisciente é abandonado. Nos contos policiais da última safra, Hernández não dá palpite. A narrativa emoldurada do delegado aposentado Laurenzi, no passado, impede quaisquer correções no rumo das investigações. O fracasso já está consumado. Laurenzi fala e Hernández escreve, aproximando-se às formas da literatura testemunhal.

Em 1956 Walsh lançou-se a investigar um crime, uma ilegalidade que primeiro caracterizou como um excesso ou uma arbitrariedade policial. $\mathrm{Na}$ primeira versão, de 1957, de Operación Masacre consta:

\begin{abstract}
Reitero que esta obra no persigue un objetivo político ni mucho menos pretende avivar odios completamente estériles. Persigue una entre muchas - un objetivo social: el aniquilamiento a corto o largo plazo de los asesinos impunes, de los torturadores, de los 'técnicos' de la picana que permanecen a pesar de los cambios de gobierno, del hampa armada y uniformada. ${ }^{33}$
\end{abstract}

E, no epílogo dessa mesma versão, diz: "Este caso está en pie, y seguirá en pie todo el tiempo que sea necesario, meses o años“34.

$\mathrm{Na}$ medida em que a investigação avançava, Walsh perdeu as referências, as certezas. Começou a duvidar de que lado estava o bem. Abandonou o espaço homogêneo e geométrico do policial de enigma. Abandonou a confiança na possibilidade de mapear a realidade. E isso tem conseqüências nas suas ficções policiais. Com a troca de dupla, Hernández/Jiménez por Hernández/Laurenzi, Daniel Hernández, o alter ego 
do autor, fala cada vez menos, escuta e registra o fracasso do delegado Laurenzi. Vai percebendo que a vida não é um tabuleiro de xadrez e no jogo da vida não se podem prever as jogadas futuras assim como em Transposición de jugadas. A aposentadoria do investigador é um atestado de incapacidade de desvendar a totalidade da verdade e evitar os crimes. A narração emoldurada é em primeira pessoa: Laurenzi rememora a derrota numa mesa de café, confidencia-se com o amigo, testemunha do relato, que o registra.

Estas modificações formais coincidem com as sucessivas reescritas de Operación Masacre, em cada uma das quais o autor acrescenta uma reflexão sobre o fracasso nos seus objetivos iniciais. No epílogo da segunda edição de Operación Masacre, de 1964, depois de ter acabado a investigação de outro crime de Estado, o caso da morte do advogado Satanowsky, diz:

Cuando escribí esta historia, yo tenía treinta años. Hacía diez que estaba en el periodismo. De golpe me pareció comprender que todo lo que había hecho antes no tenía nada que ver con cierta idea de periodismo que me había ido forjando en todo ese tiempo, y que esto sí -esa búsqueda a todo riesgo, ese testimonio de lo más escondido y doloroso-, tenía que ver, encajaba en esa idea. Amparado en semejante ocurrencia, investigué y escribí enseguida otra historia oculta, la del caso Satanowsky. Fue más ruidosa, pero el resultado fue el mismo; los muertos bien muertos; y los asesinos probados, pero sueltos. ${ }^{35}$

O "detetive" Walsh reconheceu sua fragilidade individual e a necessidade da colaboração solidária, da confiança nas testemunhas para fazer avançar a investigação e atingir seus objetivos de fazer justiça às vítimas e evitar novos crimes. Nas seguintes investigações, Caso

35 WALSH, Rodolfo. Operación masacre. Ed. cit., p. 222. 
Satanowsky e ¿Quién mató a Rosendo?, Walsh já não se lançou sozinho à tarefa.

Sua última ficção policial é de 1961. Porém, em 1969, na nota preliminar de ¿Quién mató a Rosendo?, a última das suas três grandes reportagens de investigação, diz: "Si alguien quiere leer este libro como una

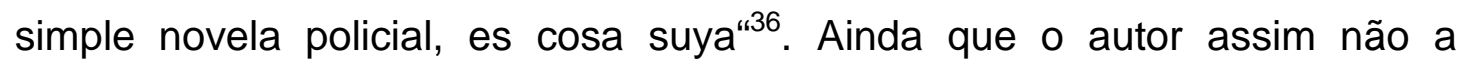
considere, ele não descarta que o texto seja lido como um policial. Sobre essa ambigüidade, Alabarces comenta: "Es una resolución paradójica: si por un lado la hibridación genérica de Walsh está afirmada en una tradición argentina, constituye al mismo tiempo un gesto de vanguardia“37. O próprio título da reportagem, como lembra Feinmann, aponta para a pergunta clássica do gênero: "whodunit".

Porém, em 1969, Walsh já não é como o personagem do escritor "Hunter" de Sábato em El túnel. Não é um detetive romântico. Como Daniel, ambiciona decifrar a informação encriptada, mas o faz apoiando-se no trabalho da equipe do periódico CGT, da central dos trabalhadores, que o escritor dirige. A equipe possui uma rede de informantes, são os militantes de base, lutadores sindicais, alguns simples trabalhadores que colaboram. É um Daniel com paciência, que já não apenas lê com lentidão, mas que ouve a rede de testemunhas que também são protagonistas daquilo que o jornalista

36 WALSH, Rodolfo. ¿Quién mató a Rosendo? 7ª Edição. Buenos Aires: de la Flor, 1997, p. 9.

37 ALABARCES, Pablo. "Dialogismos y géneros populares". In: LAFFORGUE, Jorge e outros. Textos de y sobre Rodolfo Walsh. Buenos Aires: Alianza, 2000, p. 36. 
e também colaborador do periódico Rogelio García Lupo chamava de folletín de la clase obrera, publicado pela primeira vez como uma série de reportagens em números seqüenciais da publicação $C G T$, recolhendo informações e modificando a configuração do próprio combate que os atores travavam. É por esse motivo que para Walsh ¿Quién mató a Rosendo? já não podia ser lida como literatura policial. A passagem do detetive à ação política o leva a procedimentos literários próprios da literatura de testemunho e da literatura militante. Já não se trata do detetive individual, escreve Walsh em Caso Satanowsky: "Cuando en una comunidad basicamente sana fallan determinadas instituciones, otras las reemplazan, o las reemplazan simples particulares. Ése es un índice de salud y de vigor “38. 


\section{Capítulo 2: A trilogia de investigação}

\section{Jornalismo, testemunho e militância}

Rodolfo Walsh escreveu Operación Masacre ${ }^{39}$, Caso Satanowsky ${ }^{40}$ e

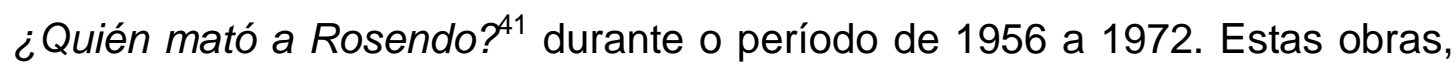
consideradas pela fortuna crítica ora como parte da literatura de testemunho, ora como textos de jornalismo investigativo ou como textos de literatura de não-ficção, incluem procedimentos próprios da literatura de testemunho e de operações de ação política envolvendo trabalho de inteligência e contrainteligência. Estes movimentos, o do testemunho e o da ação política, são de natureza ambivalente: literária e extraliterária. Ou, melhor, são movimentos que tendem a pensar a prática literária como método de conhecimento e de luta política. O estudo desta trilogia, por outro lado, não pode evitar a discussão sobre o testemunho dentro da história literária latino-americana.

A literatura de testemunho surge da necessidade literária ou extraliterária de encontrar as formas adequadas para narrar a violência e remete-nos sempre a cruzamentos entre literatura e história, ou entre literatura e política.

A fortuna crítica sobre o testemunho latino-americano engaja-se em duas vertentes fundamentais que também supõem recortes e hierarquias

39 Foi primeiro publicada como uma série de reportagens de investigação na revista Maioria em e teve quatro versões em forma de livro em 1957, 1964, 1969 e 1972.

40 Seu conteúdo foi publicado de maneira fragmentária e na forma de reportagens entre junho e dezembro de 1958 e tomou forma de livro apenas em 1973.

$41 \quad$ Foi publicada como série de reportagens no jornal CGT em 1968 e tomou forma de livro em 1969. 
diferenciados da produção testemunhal da segunda metade do século XX.

Uma acepção orienta o exame de textos que, construídos a partir de múltiplas combinações de discursos literários, documentais ou jornalísticos, registram e interpretam a violência das ditaduras da América Latina durante o século XX; é ela, em parte, tributária da pauta sobre testemunho formulada pelos intelectuais reunidos no Júri do Prêmio Casa das Américas de 1969. Outra, quase absolutamente hegemônica, emerge na década de 1980, a partir do testemunho de Rigoberta Menchú, e volta-se exclusivamente para a literatura hispano-americana. Esta apresenta uma sólida sistematização, tem sido desenvolvida no espaço universitário norte-americano ou em áreas a ele vinculadas e faz fronteira com os estudos culturais. ${ }^{42}$

Esta última sistematização do testemunho latino-americano supõe a relação entre um editor solidário com uma testemunha subalterna, representativa do seu grupo social ou étnico, e o apagamento das marcas de autoria desse mediador letrado. O objetivo é afirmar a identidade e restabelecer a verdade do grupo representado frente à versão hegemônica dos fatos. Isto limita o recorte e favorece a canonização do testemunho como gênero literário bastante definido. Os autores reunidos por Beverly na Revista de crítica literaria latinoamericana, em 1992, e estudados por João Camillo Penna, no seu artigo Este corpo, esta dor, esta fome: notas sobre o testemunho Hispano-Americano, tendem a essa descrição.

O esforço de Elzbieta Sklodoska, no seu Testimonio hispanoamericano. Historia, teoría, poética, de 1991, em fornecer um mapa das obras a partir da mesma acepção de testemunho hispano-americano esbarra com obras como Operación Masacre, de Rodolfo Walsh, e La noche de Tlatelolco, de Elena Poniatowska, que não se encaixam dentro dessa

42 DE MARCO, Valéria. "A literatura de testemunho e a violência de Estado". Lua Nova - Revista de cultura e política ํㅡ 62/ 2004, p. 46. 
descrição. A solução encontrada foi associar essas obras às do New Journalism (ou non fiction) norteamericano, investigações jornalísticas romanceadas cujo texto fundador ou, melhor, paradigmático é $A$ sangue frio, de Truman Capote.

A propósito dessa filiação, Romina García contesta:

[...] para abordar el género no basta tomar en cuenta el hecho de que se trate de una forma particular de escribir sobre los hechos de lo real donde se cruzan los procedimientos investigativos propios del periodismo con las estrategias que vienen de la literatura. Si se trabaja con la noción de género desarrollada -"tipos relativamente estables de actos elocucionarios"- puede verse con claridad que esa tradición inaugurada por Walsh poco tiene que ver con la que se atribuye Capote e incluso es posible pensar que se trata de dos géneros diferentes.

La non fiction novel o el nuevo periodismo estadounidense es un género destinado a la masa, descendiente directo de las "historias de interés humano" desarrolladas en el siglo anterior por los seguidores de Hearst; es sensacionalista, demagógico, apegado a lo cotidiano y valorador de la noticia en sí misma, separada de la causa o, se podría agregar, del "para qué". ${ }^{3}$

García prefere encontrar em Operación Masacre o referente a partir do

qual se inaugura uma tradição que vincula textos do passado como El Matadero de Esteban Echeverría, Facundo de Domingo Faustino Sarmiento, Martín Fierro de José Hernández e Aguafuertes porteñas de Roberto Arlt e textos posteriores como El caso Satanowsky e ¿Quién mató a Rosendo? do próprio Walsh, Los dueños de la Tierra de David Viñas, Los vengadores de la Patagonia trágica de Osvaldo Bayer, La pasión según Trelew de Tomás Eloy Martínez e as obras de Bonasso ${ }^{44}$ e Verbitsky. Assim, o romance

43 GARCÍA, Romina. "Novela de no ficción o testimonio: uma revisión sobre el género". In: BOCHINO, Adriana A.; GARCÍA, Romina e MERCÈRE, Emiliana. Rodolfo Walsh - del policial al testimonio. Mar del Plata: Estanislao Balder, 2004, p. 114.

44 Ver, por exemplo, BONASSO, Miguel. Diario de un clandestino. Buenos Aires: Planeta, 2000 e Recuerdos de la muerte. 5a. Edição. Buenos Aires: Planeta, 2003. 
testemunhal da Argentina não se definiria necessariamente pelos mesmos critérios usados por Sklodoska. Todas as obras da série citada por García têm em comum a intencionalidade de luta política.

No caso de Walsh, essa intenção mobiliza um conjunto de gêneros discursivos desfamiliarizadores, como reconhecem Sklodoska e Amar Sánche ${ }^{45}$, que também associa a trilogia de Walsh à non fiction norteamericana $^{46}$. Atribuo essa aproximação, porém, a duas razões. Uma, contingente, é a necessidade das duas autoras de explicar Walsh ao público norteamericano, já que ambas estão vinculadas a universidades dos EUA. A outra se refere às características próprias da obra de Walsh e à própria literatura argentina.

Para Ricardo Piglia, o grande tema da narrativa Argentina é a violência. A literatura argentina forma-se junto com o Estado e associada às narrativas de Estado.

Los servicios de informaciones manejan técnicas narrativas más novelescas y eficaces que la mayoría de los novelistas argentinos. Y suelen ser más imaginativos. El único que los mantuvo a raya fue Roberto Arlt: les captó el núcleo paranoico. El complot, el crimen, la falsificación son la esencia del poder en la Argentina. ${ }^{47}$

Eso es la ficción política. Capta el núcleo secreto de una sociedad. Funciona, digamos así, transformando esos elementos que son los núcleos verdaderos, los núcleos de interpretación. ${ }^{48}$

$45 \quad$ Ver: AMAR SÁNCHEZ, Ana Maria. "La propuesta de una escritura. (En homenaje a Rodolfo Walsh)". In: BASCHETTI, Roberto. Rodolfo Walsh, vivo. Buenos Aires: de la Flor, 1994, p. 87-108.

46 Ver: AMAR SÁNCHEZ, Ana Maria. "El sueño eterno de justicia". In: LAFFORGUE, Jorge et ALL. Textos de y sobre Rodolfo Walsh. Buenos Aires: Alianza, 2000.

$47 \quad$ PIGLIA, Ricardo. Crítica y Ficción. Buenos Aires: Fausto, 1993, p. 158.

48 PIGLIA, Ricardo. Crítica y Ficción. Ed. cit., p. 167. 
O paradigma desse tipo de narrativa é o relato policial. Existe uma verdade oculta e o enredo é a procura dessa verdade.

A matriz narrativa de Walsh é o relato policial, seja enquanto tradutor, adaptador ou escritor. Por outro lado, a sua condição de jornalista profissional Ihe dá familiaridade com os procedimentos da investigação jornalística. E tanto o relato policial quanto a investigação jornalística aproximam Walsh de autores engajados no New Journalism, como Capote e Wolfe, com os quais pode partilhar procedimentos de investigação e narração. As coincidências podiam parar aí. Beatriz Sarlo, porém, no seu artigo El país de no ficción, vai mais longe: diz que Operación Masacre inaugura o non fiction. ${ }^{49}$

Mas voltemos ao testemunho tal como o descrevem os autores vinculados à crítica dos EUA. As obras paradigmáticas do recorte foram produzidas em momentos que convém repensar.

Tomemos o relato prototestemunhal Los hijos de Sánchez; autobiografia de uma família mexicana, de 1961, de Oscar Lewis. Este tipo de narrativas é filho da etnografia, procura construir um mapa do outro social e cultural dentro de um contexto histórico de Guerra Fria ${ }^{50}$ e próximo a iniciativas como a Aliança para o Progresso ${ }^{51}$, que tinham como contrapartida

49 SARLO, Beatriz. "El país de no ficción". Zona, Buenos Aires, 26 Set. 1999. Disponível em: <http://www.clarin.com/suplementos/zona/1999/09/26/i-00702e.htm>. Acesso em: 26 out.2008 às 12:36.

50 Período de maior acirramento das tensões entre os blocos comandados pelos Estados Unidos e pela União Soviética.

$51 \quad$ Política exterior dos Estados Unidos dirigida aos países de América Latina, e que 
o desenvolvimentismo latino-americano, mais ou menos nacionalista, mais ou menos populista. Tanto para os intelectuais norte americanos quanto para os intelectuais "nativos", o outro é o subalterno fora do mercado, inclusive do mercado dos bens simbólicos, fragmentário, sem consciência de si, cheio de idiossincrasias que o tornam imprevisível. Era preciso conhecer esse outro, substrato das nações "em vias de desenvolvimento", para melhor associá-lo aos projetos mais ou menos reformistas da época. Este ambiente histórico marca o interesse crescente por obras como a de Lewis.

Já Biografía de un cimarrón, de 1966, de Miguel Barnet, é produzido no contexto da Revolução Cubana, da OLAS e da Tricontinental ${ }^{52}$, iniciativas de caráter emancipatório que supunham a luta pelo controle dos meios de produção pelo "povo", os operários e camponeses, os plebeus da América Latina. A revolução social combinava tarefas nacionais, de desenvolvimento, com esse controle dos meios de produção, que incluíam também os meios de produção simbólica: as artes, a educação, os meios de comunicação de massas, a historiografia, a academia. Assim como na Europa dos anos 20, o novo impulso revolucionário estimulava o debate sobre "cultura popular" e "arte proletária". Nesse contexto, iniciativas como a de Barnet foram enxergadas como a "tomada de posse" da historiografia e da produção literária. O engajamento do conjunto da população na construção do "grande relato" (o contra-relato) é o que necessariamente o tornaria épico, porque a narrativa da "velha" opressão seria apenas o primeiro episódio ao qual seguiria o da luta, como em Los que luchan y los que Iloran, de Jorge Masetti, 
publicado pela primeira vez em 1969, justamente prologado por Walsh, e, depois, o da vitória. O enredo, que partia de uma "violência original", tendia à desvitimização do herói coletivo, tendia ao "romance de formação". Esse espírito estava nas entrelinhas de "manuais de instruções" como o texto de Margaret Randall, incluído na coletânea de Beverly: ¿Qué es y cómo se hace un testimonio?. O uso do procedimento testemunhal tem propósitos claramente militantes.

Detenho-me neste ponto no intuito de pensar na entrevista dada por Walsh a Ricardo Piglia em 1970, ano em que já havia praticamente completado sua trilogia de investigação e deixado de publicar relatos de enredo estritamente ficcional. O último deles, Ese oscuro día de justicia, foi escrito um mês após a morte do Che Guevara. No enredo, após a derrota do personagem esperado como herói, o narrador comenta: "el pueblo aprendió que estaba solo y debía pelear por sí mismo y que de su propia entraña sacaría los medios, el silencio, la astucia y la fuerza [... $]^{\text {53 }}$. Essa frase, que segundo Walsh é uma referência à morte do Che, adquiriria maior significação dentro da discussão a propósito do foquismo, que seria retomada pelo autor no último ano da sua vida, durante a polêmica com a direção da organização Montoneros, da qual faria parte.

Walsh havia conhecido Guevara em Cuba quando foi convocado por Jorge Masetti para fazer parte da equipe da recém fundada agência cubana Prensa Latina. A iniciativa era de Che, a quem Masetti conheceu em 1958, 
ainda em Sierra Maestra, quando o jornalista foi fazer uma entrevista com Fidel Castro. O episódio tornou-se conhecido porque, saindo da zona controlada pela guerrilha, o Movimento 26 de Julio, o exército de Batista confiscou a fita na qual a reportagem tinha sido registrada. Masetti voltou à zona e refez a entrevista. Parece que Che gostou da teimosia do compatriota e ficaram amigos. Em 1959, após o triunfo da revolução, convocou-o para implantar uma agência de notícias cubana. Em 1961, como resultado das tensões no seio do governo cubano, Guevara perdeu o controle da agência e a equipe de jornalistas dirigida por Masetti saiu de Prensa Latina. O jornalista voltou clandestinamente para Argentina, no contexto da Operación Sombra, que tinha o intuito de implantar um foco de guerrilha na província de Salta, o Ejército Guerrillero del Pueblo, e ali morreu em 1964, como Comandante Segundo ${ }^{54}$. Walsh afastou-se, tomou distância desse empreendimento. Não concordava com o foquismo e o julgava muito menos adequado para Argentina, com tradição de movimentos e organizações sindicais atuantes e com participação massiva. ${ }^{55}$

$\mathrm{Na}$ mesma entrevista em que fala sobre o significado histórico da morte do Che, o herói individual, fala também da possível morte do romance:

Página/12, 1993, p. 59.

$54 \quad$ Uma curiosidade literária é que a operação levava o nome de Sombra e o codinome de Masetti era Segundo como uma referência ao personagem do escritor argentino Ricardo Güiraldes, Don Segundo Sombra, do romance homônimo, do pós-modernismo, que é, de alguma maneira, um comentário pleonástico sobre a literatura gauchesca do século XIX. A escolha remetia a Martin Fierro, o codinome de Guevara nesta operação. Masetti agia em Salta como "segundo", como "sombra" daquele "primeiro gaucho", Guevara.

55 Sobre esses assuntos, ver: ARROSAGARAY, Enrique. Rodolfo Walsh en Cuba. Agencia Prensa Latina, militancia, ron y criptografía. Buenos Aires: Catálogos, 2004; BUSTOS, Ciro. El Che quiere verte. Buenos Aires: Vergara, 2007; JOUVET, Héctor. "Entrevista". Lucha armada en la Argentina no 2, Buenos Aires, trimestre março-maio 2005, p. 
Habría que ver hasta qué punto el cuento, la ficción y la novela no son de por sí el arte literario correspondiente a una determinada clase social en un determinado período de desarrollo y en ese sentido y solamente en ese sentido es probable que el arte de ficción esté alcanzando su esplendoroso final, esplendoroso como todos los finales, en el sentido probable de que un nuevo tipo de sociedad y nuevas formas de producción exijan un nuevo tipo de arte, más documental, mucho más atenido a lo que es mostrable. [...] Porque evidentemente la denuncia traducida al arte de la novela se vuelve inofensiva, no molesta para nada, es decir, se sacraliza como arte. ${ }^{56}$

Walsh lembra da obra de Barnet e se refere aos ensaístas argentinos da primeira metade do séc. XX em relação aos quais [los escritores de ficción] hemos ocupado una posición de retaguardia ${ }^{57}$. Fala então da eficácia política de ¿Quién mató a Rosendo?

A narrativa era um meio de luta que o autor considerava eficaz e o campo das narrativas era para ele, também, campo de batalha. Essas duas premissas eram convicções compartilhadas naquele momento histórico. E é nessa chave que é preciso pensar a produção, circulação e recepção da literatura de testemunho daquele período. Dentro dessa discussão, Walsh se afastava explicitamente daqueles que apostavam na literatura ficcional e em particular daqueles que apostavam no romance, como Gabriel García Márquez, por exemplo, outro colaborador de Prensa Latina ${ }^{58}$. O abandono do herói individual parece correr paralelo a essa renúncia explícita ao projeto

51-59; e ROJO, Ricardo. Mi amigo el Che. Buenos Aires: Jorge Alvarez, 1968.

56 WALSH, Rodolfo. "Hoy es imposible en la Argentina hacer literatura desvinculada de la política". In: BASCHETTI, Roberto. Rodolfo Walsh, vivo. Buenos Aires: de la Flor, 1994, p. 67.

57 WALSH, Rodolfo. "Hoy es imposible en la Argentina hacer literatura desvinculada de la política". In: BASCHETTI, Roberto. Rodolfo Walsh, vivo. Ed. cit., p. 72.

58 A propósito deste assunto, sustentei num artículo escrito em colaboração com Priscila Engel e Karen García Delamuta, que é possível ler Cien años de soledad numa chave testemunhal: ADOUE, Silvia; DELAMUTA, Karen García; e ENGEL, Priscila. "Cem anos de solidão e o massacre de Aracataca". Revista Espaço Acadêmico, n 74, jul/2007, ano VII. Disponível em: <http://www.espacoacademico.com.br/074/74adoue.htm>, Acesso em: 26 out. 2008 às 12:52. 
de escrever um romance. Se o romance dá conta da totalidade da vida, o abandono das certezas parece ter conduzido o autor a uma desconfiança em relação a essa forma narrativa e à preferência pelo relato testemunhal, necessariamente fragmentário, talvez mais próximo ao formato do conto, que conserva certas características do relato oral, da confidência.

A outra obra paradigmática apresentada como tal pela fortuna crítica convocada por Beverly é Me llamo Rigoberta Menchú y así me nació la conciencia, publicado em 1981, de Elizabeth Burgos. A autora recolheu o depoimento de Rigoberta Menchú, membro de uma comunidade indígena de Guatemala que bateu na porta da autora em Paris para denunciar as violências sofridas por sua família e sua comunidade. Na época, Menchú era uma jovem que havia aprendido recentemente a falar castelhano, língua na que se comunicava com Burgos. A obra circulou primeiramente na Europa e nos Estados Unidos entre um público letrado bem distante das comunidades rurais da América Latina, e a denúncia rendeu a Rigoberta Menchú o Premio Nobel da Paz. Ainda que esta e outras obras dos anos 80 em diante guardem semelhanças formais com textos testemunhais do período anterior, há novas condições de produção, circulação e recepção que terminaram definindo a abordagem teórica hoje hegemônica e que é aplicada inclusive aos relatos anteriores. Isto é, foi a chave de leitura do livro de Burgos que marcou, a posteriori, o olhar sobre o livro de Barnet.

\section{As particularidades da obra investigativa de Walsh}


Roberto Ferro, no seu "Operación Masacre": investigación y escritura, estudou com minúcia e reconstruiu o processo de escrita de Operación Masacre e Caso Satanowsky associando-o ao processo de investigação. Ferro fornece um mapa da relação entre ambas atividades. Com rigor de detetive, Walsh registra cada informação indicando com detalhe como a obteve, em que data e, às vezes, até a que horas. Por meio da escrita, mobiliza testemunhas e hostiliza responsáveis, obrigando-os a falar. Não em vão Walsh era bom jogador de xadrez. A pressão sobre os suspeitos lembra o comportamento da dupla detetive/jornalista no seu primeiro conto policial: Las tres noches de Isaías Bloom.

Nos seus textos estão as vozes das vítimas, as dos assassinos, as dos mandantes, as dos juízes, as dos vizinhos que viram alguma coisa e a do próprio Walsh. Não há apagamento da voz do autor. Preserva o anonimato das fontes quando necessário, mas não dilui as personagens num magma amorfo. Observamos os deslocamentos dessas vozes. O narrador não é onisciente, é narrador/detetive que expõe suas dúvidas e fracassos. Essa posição supõe ao mesmo tempo uma estratégia persuasiva do escritor e propagandista e uma postura política do militante. A propósito disto, Ricardo Piglia diz:

Por un lado, otra vez, el intelectual, el letrado, enfrenta al Estado, hace ver que el Estado está construyendo un relato falso de los hechos. Y para construir esa contrarrealidad, registra las versiones antagónicas, sale a buscar la verdad en otras versiones, en otras voces. Se trata de hacer ver cómo ese relato estatal oculta, manipula, falsifica, y hacer aparecer entonces la verdad en la versión del testigo que ha visto y ha sobrevivido. Si ustedes leen Operación masacre verán que va de una voz a otra, de un relato al otro, y que esa historia es paralela a la desarticulación del relato estatal. Esos obreros peronistas de la resistencia que han vivido 
esa experiencia brutal, y le dan al escritor fragmentos de la realidad, son los testigos que en la noche han visto de frente el horror de la historia.[...]

El narrador entonces es el que sabe transmitir esas voces. En ¿Quién mató a Rosendo? hay momentos extraordinarios en esa representación del decir. Esa voz que se oye tiene el tono de la voz popular. Es la oralidad que define un uso del lenguaje, una manera de frasear. Walsh, básicamente, escucha al otro. Sabe oír esa voz popular, ese relato que viene de ahí, y sobre ese relato trata de acercarse a la verdad. Va de un relato al otro, podría decirse. De un testigo al otro. La verdad está en el relato y ese relato es parcial, modifica, transforma, altera, a veces deforma los hechos. Hay que construir una red de historias alternativas para reconstruir la trama perdida. Por un lado, oír y transmitir el relato popular, y al mismo tiempo desmontar y desarmar el relato encubridor, la ficción del Estado. Ese doble movimiento es básico y Walsh es un artífice notable de ese trabajo con las dos historias: la contra-ficción estatal y la voz del testigo, del que ha sobrevivido para narrar. Los vencedores escriben la historia y los vencidos la cuentan. Ese sería el resumen: desmontar la historia escrita y contraponerle el relato de un testigo. ${ }^{59}$

Esses procedimentos percorrerão também seus contos e suas cartas

pessoais, textos estudados também neste trabalho.

Essa postura descarta o papel de herói épico para si e para os outros personagens. Tampouco há heróis romanescos, há apenas homens e mulheres que se atrevem, em maior ou menor medida, a um pequeno gesto. Homens e mulheres que vão somando, contribuindo cada um com o que tem ou com o que pode dar. Walsh registra no prólogo de Operación Masacre:

Así, que ambulo por suburbios cada vez más remotos del periodismo, hasta que al fin recalo en un sótano de Leandro Alem donde se hace una hojita gremial, y encuentro un hombre que se anima. Temblando y sudando, porque él tampoco es un héroe de

59 PIGLIA, Ricardo. La ficción paranoica. Buenos Aires: Universidad de las Madres de Plaza de Mayo, I Seminario de Análisis Crítico de la realidad argentina 1984-1999, 25 set. 1999 (informação verbal). Esta conferência de Ricardo Piglia tem diferentes versões publicadas também em diferentes suportes. Veja-se, por exemplo, PIGLIA, Ricardo. "Tres propuestas para el próximo milênio (y cinco dificultades)". In: e ROZITCHNER, Leon. Tres propuestas para el próximo milenio (y cinco dificultades)/Mi Buenos Aires querida. Buenos Aires: 2001, p. 5-42; e PIGLIA, Ricardo. “¿Qué va a ser de ti?". In: Radar, suplemento de Página/12, Buenos Aires, 23/12/2001, p. 8. No en tanto, a versão utilizada neste trabalho é a que circulou em forma mimeografada. 
película, sino simplemente un hombre que se anima, y eso es más que un héroe de película. ${ }^{60}$

Al día siguiente vamos a ver al otro que se salvó, Miguel Ángel Giunta, que nos recibe con un portazo en las narices, no nos cree cuando le anunciamos que somos periodistas, nos pide credenciales que no tenemos, y no sé qué le decimos, a través de la mirilla, qué promesa de silencio, qué clave oculta, para que vaya abriendo la puerta de a poco y vaya saliendo, cosa que lleva como media hora, y hable, que le lleva mucho más. (p. 21-22)

E, nesse gesto de poner el cuerpo, deixam de ser o que eram. Essa possibilidade de mudar, que o gesto de resistência à ficção de Estado cria, supõe um movimento de sentido contrário ao relato etnográfico. A narrativa antropológica fixa os personagens, estereotipa, exotiza. Os personagens de Walsh não permitem essa recepção. A verdade improvável que formulam convoca a uma recepção bem menos passiva. É quase uma pergunta, um pedido de confirmação ou retificação, um problema que desafia, em primeiro lugar, os próprios personagens e o narrador.

As obras que integram a trilogia foram publicadas inicialmente na forma de séries de reportagens de investigação. Este formato e os meios que veiculavam tais reportagens faziam uma seleção dos primeiros leitores. Em princípio, a intenção de Walsh era publicar a série que depois resultaria em Operación Masacre na grande imprensa. Mas a grande imprensa não se interessou. Publicou as reportagens, então, numa "folhinha sindical" de pouco alcance: Mayoría.

Y la historia sale, es un tremolar de hojitas amarillas en los kioscos, sale sin firma, mal diagramada, con los titulos cambiados, pero sale. La miro con cariño mientras se esfuma en diez millares de manos anónimas. (p. 20)

60 WALSH, Rodolfo. Operación masacre. 21a . Ed. cit., p. 20. Neste capítulo, as referências a Operación masacre que aparecem a seguir indicam as páginas desta edição. 
Os leitores dessa "folhinha" não eram "neutros", se é que há leitores "neutros". Eram trabalhadores peronistas. Gente até então não habituada a se "meter em política", mas os tempos estavam mudando. Um golpe militar tinha derrubado o governo de Perón em 1955 e a censura impedia até que se mencionasse o nome do presidente deposto; a legislação trabalhista tinha sido parcialmente derrogada e o presidente de fato, o general Pedro Eugenio Aramburu, havia mandado fuzilar o general Juan José Valle, de quem era padrinho de casamento, e que havia tentado restaurar o governo constitucional em 1956. Durante essa tentativa dos generais Valle e Tanco, houve também fuzilamentos de civis envolvidos no movimento. As primeiras denúncias em Mayoría falavam em fuzilamentos de civis que não tinham vínculos com o movimento, num lixão da periferia, na mesma noite do levantamento. Eram treze civis que se haviam encontrado na casa de um vizinho para escutar a transmissão radiofônica da luta do boxeador Lausse. Esses trabalhadores, entre os quais circulava Mayoría, que simplesmente eram peronistas, estavam desacostumados na sua grande maioria com as greves, sem abrigo de sindicatos forjados para a luta, já que os sindicatos, durante o período dos primeiros governos peronistas, 1946-1955, eram quase que uma instituição paraestatal. À falta de instâncias orgânicas, a folhinha sindical dava tema para a conversa no intervalo do serviço, no café ou depois do futebol e no almoço familiar dos domingos, que eram as formas de sociabilidade próprias desse período entre as classes populares. 
Notemos a diferença com os leitores de Me llamo Rigoberta Menchú y así me nació la conciencia. Os leitores das folhinhas sindicais nas que Walsh publicava suas reportagens reconheciam-se nos personagens.

$\mathrm{Na}$ trilogia de investigação de Walsh, as vítimas da violência preventiva do Estado "paranóico", como o caracteriza Ricardo Piglia em La ficción paranoica, tendem a se livrar da pecha demonizante e a se desvitimizar. Testemunhar serve também para isso. Em ¿Quién mató a Rosendo?, Walsh explicita: "Para los diarios, para la policía, para los jueces, esta gente no tiene historia, tiene prontuario“61.

Mas o ato de falar, que exige a contrapartida do ato de ouvir, permite construir uma história, com o ouvido solidário e a memória compartilhada como suportes. A escrita deixa de ser um registro fixo, porque a cada entrega, a cada reportagem da série, o enredo se reconstrói. A série reproduz algumas das condições de produção, circulação e registro do relato oral, porém com alcance e velocidade inusitados. A máquina narrativa, produtora de sentidos, está montada. E foi construída numa "oficina de fundo de quintal", com recursos materiais mínimos, de refugo, emprestados de diversos gêneros literários e discursivos. As escolhas formais não seguem qualquer cânone ou manual; vão fundar um novo cânone. Walsh falará depois do "ofício de escritor", como uma atividade que se aprende por tentativa e erro. Nesses textos há um esforço para convencer os outros para

61 WALSH, Rodolfo. ¿Quién mató a Rosendo? 7ª Edição. Buenos Aires: de la Flor, 1997, p. 7. Neste capítulo, as referências a ¿Quién mató a Rosendo? que aparecem a seguir 
que se somem à investigação e ajudem a construir a verdade. Por esse motivo, o discurso e o formato mudam a toda hora. Até o registro lingüístico muda, como veremos ao estudar as obras, quando o narrador/detetive se dirige a um delegado, a um promotor, a um matador de aluguel, a uma vítima assustada, a uma testemunha que teve um gesto de coragem. Walsh não descarta o gênero judicial, o da confidência, o da crônica, o da ameaça.

\section{Operación Masacre}

Walsh realizou a investigação dos fuzilamentos ilegais durante um putch cívico-militar em junho de 1956, que pretendia restaurar o governo eleito, derrubado por um golpe no ano anterior, com a colaboração da jornalista Enriqueta Muñiz, a quem dedicou a série de textos reunidos numa edição em formato de livro em 1957. As vítimas do massacre nada tinham a ver com o putch, fora o fato de serem trabalhadores e peronistas. $\mathrm{O}$ assassinato foi levado adiante por um grupo de policiais, num lixão de José Leon Suárez, subúrbio da Grande Buenos Aires, e aconteceu antes da proclamação da Lei Marcial, que autorizava os fuzilamentos. Se, no começo, o Estado e a grande imprensa mantiveram silêncio rigoroso sobre estes acontecimentos, as denúncias de Walsh os obrigaram a se pronunciar. A acusação do autor sobre a ilegalidade dos fuzilamentos exigia provar que eles foram prévios à vigência da Lei Marcial, esforço que ocupou um papel central na investigação. 
O livro está organizado em três partes: Las Personas, Los Hechos e Las Evidencias. Na primeira descrevem-se as personagens, na segunda, os acontecimentos. Segundo as pesquisadoras Gloria Pampillo e Marta Urtasun, essas duas primeiras partes fazem parte do que no oratio judiciário seria o narratio, no qual se apresenta o relato dos fatos envolvidos na causa, a sua descrição preliminar. Só que personagens e fatos são apresentados de maneira romanesca, em benefício da eficácia persuasiva do discurso, antecipando o caráter provatório de algumas das informações.

A apresentação das personagens inclui uma descrição das suas aspirações, suas condições de vida, suas histórias pregressas contadas em tempo passado até o momento em que se reúnem em torno a um aparelho de rádio na casa do vizinho para acompanhar a narração da luta de boxe, alheios aos acontecimentos políticos e à chegada da polícia. O encontro dos amigos é narrado no presente, tempo que acompanhará o enredo na parte seguinte. $\mathrm{O}$ relato dos fatos em Los hechos entra num ritmo vertiginoso, abandonando os rodeios demorados sobre as amizades e conversas de bairro, abundantes em Las personas. As frases vão se encurtando e, aqui e ali, o narrador pontua o horário em que a ação se passa. Então, um subtítulo nos informa: El tiempo se detiene (p. 95). O relato adquire uma aparência de delírio: sons, luzes, dores físicas. Sensações desfocadas, um pouco fragmentárias, que não podem se organizar num relato de vigília. E o tempo: perde-se a noção de tempo, tão necessária depois para provar, para demonstrar. 
¿Cuánto tiempo hace que está así, como muerto? Ya no lo sabe. No lo sabrá nunca. Sólo recuerda que en cierto momento oyó las campanadas de una capilla próxima. ¿Seis, siete campanadas? Imposible decirlo. Acaso eran soñados aquellos sones lentos, dulces y tristes que misteriosamente bajaban de las tinieblas. ( $p$. 95)

Esse tratamento do tempo é característico do discurso traumático, como foi estudado pelo pesquisador Márcio Seligmann-Silva nos seus artigos A história como trauma e Literatura e trauma: um novo paradigma. As perguntas do narrador/detetive aparecem entremeadas pela memória traumática de Horacio di Chiano, talvez em discurso indireto livre.

\begin{abstract}
Tan desconcertado está don Horacio, que no atina a dejar la bolsa. Corre, hace girar la llave de la cerradura, y antes que termine de sacar la cadena, La puerta es impulsada con violencia desde afuera, salta el cerrojo y el se ve impelido, rodeado, desbordado por el tropel de policías y particulares provistos de armas largas y cortas, que en pocos segundos inundan todas las dependencias y cuyas voces no tardarán en oírse en el patio y en el pasillo, que conduce al fondo. Todo sucede con velocidad de relámpago. (p. 61)
\end{abstract}

No conjunto da obra, o narrador em primeira pessoa organiza a inserção de diálogos reconstruídos pelas testemunhas, citações de testemunhas em estilo direto, textos de telegramas, longos trechos de declarações reproduzidas de jornais ou perante juiz, trechos de versões taquigráficas de prestação de contas dos acusados à Junta Consultiva. $\mathrm{O}$ registro da narração passa do jargão judiciário e policial ao coloquial, às vezes provocando contrastes de efeito irônico: "A un individuo, Livraga, se lo detiene un día en que están en vigencia las leyes ordinarias. No se le acusa formalmente de nada, pero todavía no hay delito en esa detención. Es cierto que le dan unos golpes: olvidémoslos“ (p. 170). 
$\mathrm{Na}$ terceira parte, que corresponderia ao probatio judiciário, o narrador desenvolve todo o edifício probatório valendo-se de argumentos e contraargumentos que respondem à refutação resultante da publicação da série de reportagens, contestadas pelos acusados durante os processos judiciários e publicados ou comentados na grande imprensa.

As três partes, porém, podem nos remeter ao texto fundacional da ensaística argentina: o Facundo de Domingo Faustino Sarmiento. Também nesse texto de 1848 há três partes. Na primeira há uma descrição geográfica do Ilano, na segunda há uma descrição dos tipos humanos que nele vivem e só na terceira aparece a crônica histórica. A ordenação supõe uma relação causal: é a natureza que determina o caráter do povo e é essa natureza quase zoológica que gera a história. O substrato ideológico é conformado pelas teorias climáticas, as teorias raciais e o darwinismo social spenceriano. É sobre essa base que se fundou o ideologema "civilização x barbárie" como modelo explicativo do atraso relativo das nações latino-americanas. Esse modelo está presente também em Os sertões, de Euclides da Cunha, com a sua estrutura tripartita: A terra, O homem, A luta. Mas o escritor brasileiro, sem romper com o substrato ideológico hegemônico na América Latina na segunda metade do século XIX, na Nota Preliminar ${ }^{62}$ do seu texto reconhece a violência estatal contra os não letrados, vistos como encarnação da barbárie, como um crime. Esta articulação é divergente da de Sarmiento, que julgava ser o sangue dos gauchos seu único traço humano e que, por isso

62 CUNHA, Euclides da. Os Sertões (Campanha de Canudos). $2^{\mathrm{a}}$ Ed. São Paulo: Ateliê, Imprensa Oficial do Estado, Arquivo do Estado, 2001, p. 67. 
mesmo, não devia ser poupado.

O Walsh antiperonista de $1956^{63}$ enxergou essa violência do Estado contra os pobres, e por isso suspeitos de barbárie, como um "desatino". O autor registra na introdução à primeira edição da série de reportagens na forma de livro e, portanto, dirigida a um público mais amplo que o das "folinhas sindicais", um público que inclui seus pares, os letrados:

\begin{abstract}
Suspicacias que preveo me obligan a declarar que no soy peronista, no lo he sido ni tengo intención de serlo. (p. 192)

En los últimos meses he debido ponerme por primera vez en contacto con esos temibles seres -los peronistas- que inquietan los titulares de los diarios. $Y$ he llegado a la conclusión (tan trivial que me asombra no verla compartida) de que, por muy equivocados que estén, son seres humanos y debe tratárselos como tales. Sobre todo no debe dárseles motivos para que persistan en el error. Los fusilamientos, las torturas y las persecuciones son motivos tan fuertes que en determinado momento pueden convertir el error en verdad. (p. 68)
\end{abstract}

Más que nada temo el momento en que humillados y ofendidos empiecen a tener razón. Razón doctrinaria, amén de la razón sentimental o humana que ya les asiste, y que en último término es la base de aquélla. Y ese momento está próximo y llegará fatalmente, si se insiste en la desatinada política de revancha que se ha dirigido sobre todo contra los sectores obreros. La represión del peronismo, tal como ha sido encarada, no hace más que justificarlo a posteriori. Y esto no sólo es lamentable: es idiota. ( $p$. 68)

A estratégia de comunicação de Walsh inverte a ordem do referente sarmientino, elimina a descrição da geografia e inclui a disputa pelo sentido: primeiro Las personas, com seu perfil humanizado; depois Los hechos, como crônica da violência de Estado; por último Las evidencias, como luta pelo

63 No Provisório epílogo à primeira edição, aparece: "Puedo, sin remordimiento, repetir que he sido partidario del estallido de setiembre de 1955" (p. 215), se referindo ao golpe que derribou o governo de Juan Domingo Perón. 
estabelecimento da verdade do contra-relato. A própria estrutura é uma ação política, uma disputa dentro de uma tradição do ensaio, ao manter a organização em três partes e ao modificar a ordem e a composição delas.

Há três reedições do livro, a de 1964, a de 1969 e a de 1972. A organização do material nas três partes é mantida em cada uma delas. Essas reedições mantiveram o caráter provisório das versões enunciadas, incluíram novos personagens e os acontecimentos narrados inicialmente aparecem como os primeiros episódios de um relato cada vez maior.

$\mathrm{Na}$ primeira edição, o prólogo de Walsh explica que a obra foi publicada inicialmente como uma série de reportagens e pede aos leitores para difundir o acontecido, que é caracterizado como uma monstruosidade, uma anormalidade. A introdução inocenta o governo da Revolução Libertadora, que 0 autor havia recebido com esperança, das responsabilidades pelo crime e toma distância das posições dos peronistas. Um Provisorio epílogo relembra a noite de 9 de junho e as escaramuças entre soldados leais e insurgentes que resultaram na morte do soldado Bernardino Rodríguez junto à janela da casa do autor, já mencionada neste trabalho:

Si hay algo justamente que he procurado suscitar en estas páginas es el horror a las revoluciones, cuyas primeras víctimas son siempre personas inocentes, como los fusilados de José León Suárez o como aquel conscripto caído a pocos metros de donde yo estaba. La pobre gente no muere gritando 'Viva la patria', como en las novelas. Muere vomitando de miedo, como Nicolás Carranza, o maldiciendo su abandono, como Bernardino Rodríguez. (p. 218) 
Essa primeira edição, termina responsabilizando pelo massacre ao chefe da Polícia provincial, tenente coronel Desiderio Fernández Suárez.

Na segunda edição, de 1964, o epílogo muda. Nele, o autor fala da situação dos sobreviventes e faz uma declaração de fracasso. Se em 1957 afirmava: este caso sigue en pie, agora solicita: de esa frase culpable pido retractarme (p. 221) e expõe toda sua decepção pela impotência da sua denúncia.

Na terceira edição, de 1969, o autor acrescenta ao epílogo uma página dedicada ao Retrato de la oligarquía dominante. Nele faz um levantamento dos feitos mais importantes da violência de Estado desde 1956, incluindo os resultados das suas outras duas investigações. E conclui: "Era inútil en 1957 pedir justicia para las víctimas de la 'Operación Masacre' [...] Dentro del sistema, no hay justicia" (p. 223-224).

Na última edição, de 1972, o prólogo retoma a lembrança da noite de 9 de junho de 1957. Nele Walsh fala do seu desejo de esquecer, sua resistência e, por fim, a investigação. Os acontecimentos daquela noite remetem à morte do soldado Bernardino Rodríguez. A figura do soldado que ali estava por ter sido convocado para fazer o serviço militar e não por vontade própria aparecerá depois pelo menos três vezes na obra de Walsh: no conto Imaginaria, na peça de teatro La granada e em Carta a mis amigos. A morte de Bernardino Rodríguez parecia carecer de qualquer sentido. E 
suas últimas palavras, recolhidas por Walsh, são apresentadas como uma revelação da banalidade do acontecimento. No enredo de La granada, em meio a exercícios simulados de guerra, um recruta fica preso a uma bomba que pode explodir a qualquer momento. O soldado é uma espécie de préfiguração de um cadáver, que, ao ter seu desejo de vida alienado, vira um objeto.

O recruta é convocado e entra nas guerras sem ter bando. Mas havia um outro soldado no imaginário de Rodolfo Walsh. Um tio seu, William, que o autor não chegou a conhecer, havia embarcado em Buenos Aires em direção a Europa, para combater a favor de Hitler. Isto é, contra os ingleses, como bom irlandês. No barco, outros compatriotas o convenceram da necessidade de lutar contra Hitler. Morreu em Salónica, na batalha contra as tropas do Eixo. O tio Willy podia ter morrido num ou no outro bando, tanto fazia. Nem sabia direito, ao partir de Buenos Aires, qual era o "bando certo". Walsh planejava um conto para a série dos irlandeses ${ }^{64}$, chamado Mi tío Willy ganó la guerra ${ }^{65}$, examinado no próximo capítulo.

Mas o tio Willy retornou à vida de Walsh também em junho de 1956 da mão de um outro William, também irlandês. Nesse mês, o autor traduzia e condensava Operation Heartbreak para a revista Leoplán, onde trabalhava. A novela de Cooper contava a história de William Martin, um soldado irlandês,

64 A série é formada por três contos, mas Walsh projetava escrever pelo menos dois mais. Os que foram publicados são: WALSH, Rodolfo. "Irlandeses detrás de un gato"; "Los oficios terrestres" e "Un oscuro día de justicia". In:Cuentos. Buenos Aires: Biblioteca Página/12, 1993, p. 13-30; p. 31-40; e p. 41-60.

65 Sobre o projeto para este conto, Walsh fala na p. 65 da entrevista feita por Ricardo Piglia em 1970, Hoy es imposible en la Argentina hacer literatura desvinculada de la política, 
membro do exército inglês, que nunca tinha entrado em combate. Após uma decepção amorosa e sentindo-se um fracassado, entra em depressão, contrai pneumonia e morre. Sua irmã de criação, que havia rejeitado seu pedido de casamento, comunica a morte de Martin ao seu superior, um oficial de inteligência. O militar desenvolve uma operação na qual o cadáver de William aparecerá nas águas "neutrais" da Espanha, vítima de um forjado desastre aéreo, portando documentos que confirmam o desembarque aliado na Grécia, para distrair as forças do Eixo da Sicília, verdadeiro destino do desembarco. O serviço secreto alemão cai na armadilha e William Martin é promovido post mortem. Entre os documentos "secretos", porta uma carta pessoal apócrifa, assinada pela mulher que o havia rejeitado. $\mathrm{Na}$ carta, ela confessa seu amor e arrependimento: "Darling, my darling, you are going away from me and I have never told you how much I love you. How sad, how heartbreaking it would be if you had never known. But "this will tell you, and this you must take with you on your dark ${ }^{66}$ mission." ${ }^{67}$.

Duff Cooper, diplomata, teria ficcionalizado esta operação que Ihe foi confidenciada por Churchill para explicar os motivos de Hitler para desconsiderar as informações dos seus agentes a propósito do desembarque aliado em Normandia. Hitler não teria acreditado nessas informações, lembrando da armadilha da Grécia montada com cadáver de Martin. Quando Operation Heartbreak foi publicada, o serviço secreto inglês sentiu-se

\footnotetext{
já citada.

66 O adjetivo "oscuro" ("dark") aparecerá uma e outra vez na obra de Walsh: "[...] a veces un oscuro sentimiento lo traciona" (p. 69), para descrever Vandor em ¿Quién mató a Rosendo? e no título do último conto publicado pelo autor, Un oscuro día de justicia, por exemplo. "Oscuro", na obra de Walsh, sempre está associado à idéia do improvável.

67 COOPER, Duff. "Operation Heartbreak". In: MONTAGU, Ewen e COOPER, Duff.
} 
obrigado a encomendar a um dos seus agentes, Ewen Montagu, que escrevesse um relatório sobre aquela operação, chamada na realidade Operation Mincemeat. Esse relatório foi publicado com o nome de The man who never was. Aparentemente, a intenção do serviço secreto era ocultar a identidade real do cadáver de William Martin. Walsh chamou sua condensação de Operación Desengaño com o subtítulo de El cadáver que engañó a Hitler.

Sem dúvida, o relato trouxe novamente à tona a morte do seu tio Willy na Grécia, para onde o cadáver de William Martin desviou as tropas de Hitler. E também deve ter provocado uma reflexão sobre a literatura e o trabalho de inteligência como meios capazes de construir um sentido heróico para uma morte banal, como uma reparação post mortem ao soldado irlandês, que talvez não fosse tão confiável para os ingleses, justamente por ser irlandês. Coincidentemente, na noite do dia 9 desse mês em que está condensando a novela de Cooper, Walsh testemunha a morte do "soldadito" junto à sua janela. Outra morte banal. Talvez o autor quisesse também fazer uma reparação para esse soldado Bernardino Rodríguez. Uma reparação post mortem que se estendesse aos fuzilados de José León Suárez: cadáveres "promovidos" a heróis.

As modificações nas sucessivas edições fazem tender o relato para a épica. Julio Troxler, por exemplo, um dos sobreviventes do massacre, aparece na seqüência final da versão cinematográfica de Operación 
Masacre, já convertido em militante, e esta seqüência tem seu roteiro incluído na edição de 1972, resumindo la experienca colectiva del peronismo en los años duros de la resistencia, la proscripción y la lucha armada (p. 181). Nessa mesma seqüência, jovens que seriam apenas crianças quando aconteceu o massacre, realizam ações assinadas por comandos que homenageiam Lizaso, um dos fuzilados. A literatura de Walsh tenta assim o impossível até para o realismo maravilhoso: personagens falecidas no primeiro episódio saem de sua condição de vítimas pelo encadeamento de acontecimentos posteriores ao primeiro da série, constituindo-o em ato fundacional da Resistencia Peronista, movimento que foi se afirmando entre 1956 e 1973, ano do retorno do peronismo ao governo.

Provavelmente o enredo de Operation Heartbreak foi uma fonte de inspiração para Walsh. Procedimentos literários podiam transformar uma morte banal num fato heróico. Um cadáver podia ser transformado em herói épico. Mas para isso foi necessário reescrever quatro vezes a história; refazer o enredo incluindo novos fatos que mudavam o sentido daqueles fuzilamentos de 1956.

Paralelamente às reedições de Operación Masacre, Walsh realiza as outras duas investigações. O grande tema que envolve as três obras é a violência de Estado e a procura da verdade, que se confunde com o esforço por desmontar as narrativas desse mesmo Estado.

Uma investigação chega a se cruzar com a outra: do lado de lá, os 
personagens são mais ou menos os mesmos, assim como os procedimentos de ocultamento. Walsh e seus colaboradores e companheiros aperfeiçoam a máquina narrativa, lubrificam-na, alimentam-na e fazem-na funcionar.

\section{Caso Satanowsky}

Em junho de 1957, um ano após os fuzilamentos de José Leon Suárez, é assassinado o advogado Marcos Satanowsky, que dirige um dos mais prestigiosos escritórios advocacia da capital e é titular de cátedra na Faculdade de Direito da Universidad de Buenos Aires. Sua morte acontece no contexto de uma luta entre setores das Forças Armadas pelo controle de um grande jornal. De junho a novembro de 1958, Walsh desenvolve uma investigação sobre o caso. Conhecem-se os executores, o que permanece oculto é o motivo e o mandante. A revelação, por si só, leva a um saber mais geral: os meios de comunicação, órgãos da grande imprensa, são peça fundamental para a produção das narrativas e o poder depende em grande medida do controle sobre esses meios.

A investigação e a escrita de Caso Satanowsky coincidem com a instalação do governo civil do desenvolvimentista Arturo Frondizi, eleito com a proscrição do peronismo. Durante a campanha jornalística em Mayoría, Walsh é convocado para participar da Comissão Parlamentar de Inquérito que investiga o caso, mas pressões dos militares a dissolvem. $O$ governo civil, refém dos militares, começa restringindo ou sabotando as operações da 
comissão, obrigando Walsh a afinar procedimentos de inteligência que já vem utilizando, como já foi mencionado neste trabalho: às vezes, solta uma informação sigilosa como isca para obter alguma outra; em outras oportunidades, segura uma informação que tem na mão para não alertar os suspeitos e poder armar uma cilada. Roberto Ferro cita um bilhete assinado por "Freyre", o (hoje) conhecido pseudônimo de Walsh, dirigido ao editor de Mayoría:

Disculpe la tardanza, que como Usted imaginará tiene explicación. Disimule también el ritmo aparentemente lento de algunas notas, que tiene sus motivos. Creo que vamos bien. Prevea la eventualidad de sacar una edición extra, si en una de ésas logramos aclarar el caso. ${ }^{68}$

Rogelio "Pájaro" García Lupo, jornalista e amigo de Walsh, participa também da Comissão Parlamentar de Inquérito e colabora com Walsh na investigação. Depois trabalharão juntos em Prensa Latina, a agência de notícias Cubana e no periódico CGT, da central sindical combativa, que Walsh dirigirá.

A investigação resulta em duas séries de reportagens publicadas no periódico Mayoría, no qual também havia publicado grande parte das reportagens do que depois seria Operación Masacre. A primeira série é composta de quinze reportagens que aparecem de 9 de junho até 15 de setembro de 1958 e a segunda consta de doze que vão de 6 de outubro até 28 de novembro do mesmo ano.

68 WALSH apud: FERRO, Roberto. "Escritura periodística y poderes políticos". In: 
$\mathrm{Na}$ última matéria da primeira série, Walsh apresenta as Conclusiones $^{69}$, nas que afirma que o assassinato do advogado é um "crime oficial", que houve "pasividade judicial" e "encobrimento policial"; também aponta um dos autores materiais e dois oficiais das forças armadas como suspeitos. Para cada uma dessas afirmações, apresenta provas. Na mesma reportagem registra um Provisório epílogo ${ }^{70}$ no qual lembra que a finalidade da investigação era apurar as responsabilidades dos funcionários do Estado que não resolveram o caso, reconstruir os acontecimentos e descobrir a motivação do crime.

Depois da aparição de uma matéria na revista Panorama, desqualificando Walsh e os resultados do seu trabalho, o detetive/jornalista lança a segunda série e começa contestando a revista. Segundo Roberto Ferro:

Si el relato que articulaba la primera serie de notas de Caso Satanowsky se cruzaba con la narrativa policial de enigma, la segunda serie, simétricamente, se interfecta con la policial negra; la causalidad ya no está ordenada por la lógica sino por la violencia, el factor económico que rige las relaciones. El periodista-detective ya no descifra misterios, se mueve en un mundo en el que la competencia individualista propia del capitalismo termina e impone su dogma de apropiación. El crimen es un modo privilegiado de exponer las relaciones sociales. ${ }^{71}$

O conjunto de reportagens só é reunido em forma de livro em 1973, com atualizações do autor. Este livro também está organizado em três partes: Los hechos, La investigación e Las enseñanzas, com uma nota prévia que

WALSH, Rodolfo. El caso Satanowsky. Buenos Aires: de la Flor, 1997, p. 214.

69 WALSH, Rodolfo. El caso Satanowsky. Ed. cit., p. 241-246.

70 WALSH, Rodolfo. El caso Satanowsky. Ed. cit., p. 246-248.

71 FERRO, Roberto. "Escritura periodística y poderes políticos". In: WALSH, Rodolfo. El caso Satanowsky. Ed. cit., p. 218. 
retoma as condições da investigação e publicação em Mayoría. Esta obra, já sem a urgência de Operación Masacre, oferece aos leitores um diário do detetive/jornalista, com abundante material gráfico (fotos e fac-símiles) e descrição do processo de obtenção da informação. Há reconstruções de diálogos, reprodução de panfletos apócrifos, operações dos serviços de inteligência do Estado, registro de declarações de testemunhas perante o próprio Walsh, textos de telegramas utilizados como provas.

O Estado valeu-se, para o assassinato, da participação de pistoleiros de aluguel cujo testemunho, podia ser facilmente desqualificado em caso de “arrependimento". Um deles, Pérez Griz, primeiro dá pistas que podem levar aos mandantes e depois muda suas declarações. Walsh dirige-se a ele:

\footnotetext{
Usted no es exactamente una buena persona. Entre nosotros, digamos que es más bien un desgraciado. Cuantas veces tuvo mujer a su lado, la explotó y maltrató. Cuantas veces tuvo un amigo, le hizo alguna porquería. Usted ha sido ventajero y alcahuete. No hablo de sus delitos porque se puede ser un delincuente y conservar ciertas formas de dignidad. Usted las ha perdido casi todas, y si quiere salvar alguna, tiene que venir al pie.

[...] Por si le sirve de consuelo, sepa que los únicos que lo benefician con un silencio que no merece, son su mujer legítima y su hijo de quince años, a quienes usted ha sumergido en la desgracia. De los demás, todos lo han escupido, y con razón.

[...] Si se le acercan, tenga cuidado. Míreles las manos y no deje que le pongan las manos en la espalda. No sea que en una de esas le hagan la boleta, por tantas cosas que sabe. ${ }^{72}$
}

Propõe, no final, que entregue os mandantes, argumentando que é o jeito de salvar a vida. O discurso é ameaçador, mas ao mesmo tempo oferece ao executor do crime uma possibilidade, estudando o tipo humano e 
adivinhando seus interesses, apelando para alguma culpa ou algum afeto.

registro permite uma comunicação com algum nível de cumplicidade, digamos, cultural, semelhante ao da dupla detetive/jornalista ao se dirigir aos suspeitos no conto Las tres noches de Isaías Bloom, já citado.

A publicação, em 1973, tem mais um caráter "pedagógico". Entre a escrita de Caso Satanowsky e ¿Quién mató a Rosendo?, Walsh viaja a Cuba e se integra à agencia Prensa Latina, dirigida por Jorge Masetti. Além da relação com Masetti, Walsh entra em contato com Barnet, e com os entusiastas da literatura de testemunho, e com escritores latino-americanos simpáticos à revolução. Na já citada entrevista a Ricardo Piglia, Walsh diz, opondo a literatura de testemunho à forma do romance:

\begin{abstract}
Ahora, en mi caso personal, es evidente que yo me he formado o me he criado, dentro de esa concepción burguesa de las categorías artísticas y me resulta difícil convencerme de que la novela no es en el fondo una forma artística superior; de ahí que viva ambicionando tener tiempo para escribir una novela a la que, presupongo, sin duda hay que dedicarle más tiempo, más atención y más cuidado que a la denuncia periodística que vos escribís al correr de la máquina. Creo que es poderosa, lógicamente muy poderosa, pero al mismo tiempo creo que gente más joven, que se forma en sociedades distintas, sociedades no capitalistas o bien que están en proceso de revolución, van a aceptar con más facilidad la idea de que el testimonio y la denuncia son categorías artísticas por lo menos equivalentes y merecedoras por lo menos de los mismos trabajos y esfuerzos que se le dedican a la ficción. En un futuro, tal vez, se aprecie en cuanto a arte sea la elaboración del testimonio o del documento, que, como todo el mundo sabe, admite cualquier grado de perfección. Evidentemente en el montaje, la compaginación, la selección, en el trabajo de investigación, se abren inmensas posibilidades artísticas. Digo esto porque pienso en trabajos como el de Barnet, por ejemplo, no tanto el segundo como en el primero, Biografía de un cimarrón... E inclusive aquí mismo, cuánta gente hay de cuyas vidas uno contaría la historia con mucho gusto realmente y sin limitaciones cuanto a lo que podés conseguir. No se trata de firmar el certificado de defunción de la novela o de la ficción, pero es muy probable que se pueda caracterizar a la ficción en general como el arte literario característico de la burguesía de los siglos XIX y XX
\end{abstract}


principalmente, y por lo tanto no como una forma eterna e indeleble, sino como una forma que puede ser transitoria. ${ }^{73}$

Abraça o discurso dos testemunhalistas, porém, não abandona o enredo ficcional. Operación Masacre e Caso Satanowsky, ainda não publicado no formato de livro, não guardam muita semelhança, nem na forma e nem nos procedimentos, com Biografía de um cimarrón, de Barnet. As obras de Walsh são, de qualquer ponto de vista, mais complexas. Mas, curiosamente, seu método de trabalho, a máquina narrativa que construiu, é muito mais adequado às intenções declaradas dos testemunhalistas da época. E muito mais eficaz, sem dúvida, do que os ingênuos "manuais de instruções" ao estilo de ¿Qué es y cómo se hace un testimonio?, de Margaret Randall.

\section{¿Quién mató a Rosendo?}

Já de volta a Argentina, Walsh recebe o convite de Juan Domingo Perón, na época no seu exílio em Madri, para dirigir o periódico da central sindical combativa ${ }^{74}, C G T^{75}$. A publicação propõe-se como pólo organizador

73 WALSH, Rodolfo. "Hoy es imposible en la Argentina hacer literatura desvinculada de la política". In: BASCHETTI, Roberto. Rodolfo Walsh, vivo. Buenos Aires: de la Flor, 1994, p. 68-69.

$74 \quad$ O órgão da central está estruturado segundo as recomendações de Lênin para o Pravda, com uma rede de correspondentes em cada local de trabalho. O correspondente é ao mesmo tempo informante e organizador.

75 A CGT, Confederación Nacional del Trabajo tinha sofrido uma divisão no Congreso Normalizador Amado Olmos, em março de 1968. Dessa divisão emergiram a CGT de los Argentinos e a CGT-RA, Confederación Nacional del Trabajo de la República Argentina. Também eram reconhecidas pelo nome da rua em que estavam suas respectivas sedes: CGT de Paseo Colón (a combativa) e CGT de Azopardo. O dirigente metalúrgico Augusto Timoteo Vandor, que havia sido eleito secretário geral da Unión Obrera Metalúrgica, de grande influência, articulou a divisão, permanecendo, porém, no seu posto e deixando o dirigente dos molineiros Vicente Roqué na secretaria geral da central sindical da CGT de 
político e chega a formular um programa transformador para o país, o Programa del $1^{\circ}$ de $M a y o^{76}$, redigido pelo próprio Walsh.

Em maio de 1966 havia sido assassinado Rosendo García, da equipe do dirigente metalúrgico pelego Augusto Timoteo Vandor, na pizzaria La Real de Avellaneda, um subúrbio de Buenos Aires. O crime tinha sido atribuído, pela polícia e pelos companheiros do falecido, a militantes sindicais combativos que ali estavam no contexto de um encontro sindical na região. Houve enfrentamento entre os dois grupos e Rosendo García foi baleado e morto. As suspeitas dos militantes combativos, porém, recaíam sobre o próprio Vandor, quem teria aproveitado a confusão para fazer um acerto de contas. O acontecimento enlaçou-se a uma cadeia de fatos tal que o tornaram um ponto de inflexão na constituição de uma esquerda peronista no campo sindical. Em 1968, Walsh investigou o assassinato e publicou uma série de reportagens sobre ele no semanário que dirigia.

A série é formada por sete notas publicadas nos números 3 a 9 do CGT, de 16 de maio a 27 de junho de 1968. Quase todas começando com Citas útiles, retiradas de relatórios judiciais, declarações dos personagens aos meios de comunicação de massas, relatórios de autopsia, que vão funcionar como chave de leitura da matéria. Todas estão acompanhadas de

\footnotetext{
Azopardo. Vandor havia "caído en desgracia" dentro do peronismo, por promover o que foi chamado "peronismo sem Perón". Juan Domingo Perón, na sua política pendular, apoiou, estando no exílio em Madri, a equipe do dirigente gráfico Raimundo Ongaro, impulsionando o lançamento do periódico CGT.

76 Esta plataforma recolhe e atualiza os pontos programáticos elaborados pelos congressos sindicais realizados em La Falda, de 1957, e em Huerta Grande, 1962, de caráter nacionalista e socializante. Inclui, porém, a luta anti-burocrática no seio das organizações sindicais, reproduzindo, por exemplo, a condena de Amado Olmos aos dirigentes que adoptaram as formas de vida e os gostos da oligarquia que diziam combater.
} 
fotos, fac-símiles e quase todas com croquis do local do crime, utilizando recursos já testados nos primeiros relatos policiais de Walsh, desta vez, com maior liberdade de diagramação, oferecida pelo suporte do periódico. Todo esse material gráfico se articula com o texto.

No final da primeira nota Walsh escreve uma advertência: "El hombre al que van dirigidas estas palabras [dirige-se a Vandor] no es mi enemigo personal. No lo conozco ni me conoce“77. E enumera os objetivos da investigação. Na quarta nota também se dirige a um dos personagens, aquele que provocou a briga entre os dois grupos na pizzaria. Na última apresenta a conclusão: a bala que matou Rosendo García só podia ter sido disparada por Augusto Timoteo Vandor. E apresenta um último croquis com o título de La evidencia.

Walsh já não é um detetive solitário que eventualmente aceita a colaboração de algum parceiro. Quem leva adiante a investigação é uma equipe de CGT. Dessa equipe participam Carlos Burgos $^{78}$ e um então muito jovem Horacio Verbitsky, além de outros colaboradores eventuais. Rogelio "Pájaro" García Lupo chamava a série de reportagens sobre o tema de "o folhetim da classe operária".

O público leitor desta série era mais numeroso que o das primeiras entregas de Operación Masacre, mas a sua composição social não era muito

77 WALSH, Rodolfo. "Quién mató a Rosendo?”. In: CGT oㅜ 3 - ano I. Buenos Aires, 16 de maio de 1968, p. 2.

78 Morto em 1989 durante a ocupação do quartel de La Tablada. 
diferente. O que era diferente, sim, era a práxis desse público leitor: tinha se politizado. Quem em 1957 lia a folhinha sindical, por exemplo, em 1968 era correspondente do periódico CGT; quem em 1957 testemunhava sobre o massacre, em 1968 era militante de alguma organização clandestina. Os seus saberes políticos cresciam em proporção direta com o seu poder de ação. A narrativização dos saberes tinha, entre outros, um efeito pedagógico, que preparava para uma avaliação mais precisa do comportamento do inimigo e dos cooptados por ele, para reconhecer quem eram companheiros, para disputar hegemonia e para se articular para a ação.

Mas ¿Quién mató a Rosendo? não se dirige apenas "aos compañeros“, assim como Operação Masacre e Caso Satanowsky. O texto tem múltiplos destinatários, e continua operando sobre o campo das narrativas no seu conjunto e nele disputando a legitimidade do relato e o reconhecimento da legitimidade do enunciador. Isto é: não só uma luta pelo enunciado, mas pela enunciação.

Como os seus relatos "irmãos", a edição em formato de livro de ¿Quién mató a Rosendo?, em 1969, está organizada em três partes: Las personas y los hechos, La evidencia e El vandorismo.

Em Las personas y los hechos, com 10 capítulos, aparece a descrição dos personagens do grupo opositor a Vandor, a do próprio Vandor e a de Rosendo García, entremeadas pelo relato do encontro em Avellaneda. O primeiro capítulo, Raimundo, começa registrando: 
Había que arreglar esa empaquetadora para que la fábrica Conen pudiera seguir empaquetando sus jabones, las farmacias los vendieran, el grupo Tornquist siguiera cobrando sus dividendos y Raimundo Villaflor comiera el puchero que comió ese mediodía del 13 de mayo de 1966. (p. 15)

É quase uma descrição sociológica, mas numa linguagem acessível ao público de CGT. Enrique Arrosagaray, ao entrevistar Indio Allende, um dos membros do grupo que se confrontou com o de Vandor na pizzaria La Real, para seu livro Rodolfo Walsh, de dramaturgo a guerrillero, lembra que o seu grupo exigiu do autor de ¿Quién mató a Rosendo? que escrevesse de maneira que os trabalhadores entendessem:

INDIO ALLENDE: ¿Vos leíste esa obra, "Un kilo de oro"? Bueno, imaginate que sea durísimamente criticada por nosotros. Entonces cuando él quiere sacar su publicación sobre lo de La Real - toma aire y habla como si volviera a hablarle a Walsh-: No te zarpés, no te vengás a hacer el pelotudo, que esta obra tiene que estar dirigida a nuestra gente, flaco, si no, no te vamos a dar los datos... -busca otras formas de decir lo mismo, como si siguiera hablándole a Walsh- i¡No, no, no flaco, a Borges la gente no lo entiende!! Esto era la lucha de clases. Todos se lo decíamos. ${ }^{79}$

Parece que Walsh acatou a exigência. O esforço para ser claro verifica-se, assim, como a captura fiel da voz das testemunhas, facilitada pelo uso de gravador.

Esse, e cada capítulo dedicado a um personagem, termina o relato biográfico nos instantes prévios ao encontro na pizzaria La Real.

O segundo capítulo, Avellaneda, é uma descrição do ambiente do

79 ALLENDE, Indio apud ARROSAGARAY, Enrique. Rodolfo Walsh, de dramaturgo a guerrillero. Buenos Aires: Catálogos, 2006, p. 67. 
bairro onde os fatos aconteceram, no melhor estilo do romance realista:

Los últimos saladeros cerraron cuando la fiebre amarilla ${ }^{80}$, pero aún perdura en las orillas del Riachuelo ese "olor peculiar" que un viajero inglés señaló hace un siglo. Los buques de la Star anidan en los muelles del Anglo, embarcando el chilled que hizo la riqueza de pocos y la miseria de tantos. Día y noche sube el ganado por las rampas de La Negra ${ }^{81}$ para caer bajo el martillo, o bajo la espada del rabino. Petroleros de doscientos metros de eslora entran cautelosamente en el Dock Sur, que ilumina de noche el fulgor anaranjado de la Shell. Millares de hombres transpiran en invierno junto a los trenes de laminación, los crisoles, los tornos. Mas que las calles largas y monótonas, más que las plazas desfoliadas por el humo y los residuos, las fábricas son aquí los puntos de referencia: la papelera, la cristalería, la Ferrum, la textil ${ }^{82}$. (p. 25)

E continua com uma revisão histórica do bairro, que se confunde com a história do movimento operário argentino. Lembra que a jornada de 17 de outubro de $1945^{83}$ se preparou, na véspera, naquela região. Esse capítulo finaliza com a localização da pizzaria dentro do bairro.

No quarto capítulo, El Lobo, que era o apelido com que Augusto Timoteo Vandor era conhecido, além da história do sindicalista, há uma descrição das suas práticas organizativas:

Ahora no necesitaba hablar, otros hablaban por él en los congresos y los confederales. Murmuraba "uno" y se paraba Avelino, "dos" y hablaba Maximiano, "tres" y recitaban su libreto Izetta o Cavalli: eso era organización.

En algún momento le pareció que comprendía la esencia del poder: ese punto de equilibrio en que nadie hace su voluntad, pero el más hábil opera con la voluntad ajena. En algún momento comprendió lo

\footnotetext{
80 Refere-se aos "saladeros" de carne para exportação e à epidemia de febre amarela de fevereiro de 1871.

81 Refere-se ao frigorífico La Negra.

82 Fábricas da região.

$83 \quad$ No 17 de outubro de 1945, trabalhadores da Capital e da Grande Buenos Aires se dirigiram à Plaza de Mayo para exigir a liberdade do então coronel Juan Domingo Perón, secretário de trabalho, que vinha dialogando com os sindicalistas e acolhendo suas reivindicações. Perón havia sido preso no contexto de uma luta interna no governo militar presidido pelo general Edelmiro Julián Farrel.
} 
que es negociación: quizá en enero del 59, cuando el correo de Ciudad Trujillo le dijo: "No se puede largar la huelga porque esta noche entregamos el toco". Desde entonces, o ya desde antes, prefirió negociar por su cuenta. (p. 38)

Sobre a relação de Vandor com Cuba registra:

Se dice que ha llorado en Cuba, al contemplar la revolución del pueblo -ese sueño enterrado-, pero luego le ha dicho a Ernesto Guevara: "Nosotros nunca podremos hacer lo que han hecho ustedes". Eso es realismo. Volverá a llorar dentro de media hora, y en el acto adoptará decisiones justas que cambian el curso de las cosas. Eso es política. (p. 39)

As frases eso es organización, eso es realismo, eso es política pontuam o texto com um efeito irônico que acompanha todo o capítulo contrastando com o tratamento dos outros personagens.

Explica a situação de Vandor dentro do peronismo:

Detrás de todo eso había una carta. Dirigida a José Alonso el 27 de enero, señalaba a Vandor como el "enemigo principal" y agregaba: "En política no se puede herir, hay que matar, porque un tipo con una pata rota hay que ver el daño que puede hacer". Firmaba Juan Domingo Perón. (p. 42) ${ }^{84}$

A descrição de Rosendo García apresenta-o como um ingênuo:

Uno de los pocos que al parecer creía en las elecciones era Rosendo García. Su nombre figuraba ya como candidato a gobernador de la provincia. Para dar ese salto, que lo arrancaría quizá definitivamente de la órbita secundaria a que estaba relegado, era preciso, desde luego, que hubiera elecciones. Pero Vandor no quería elecciones: Vandor estaba en el golpe. (p. 42)

$84 \quad$ Vale a pena dizer aqui que Vandor foi morto em 30 de junho de 1969 por um comando do Ejército Nacional Revolucionario que também matou José Alonso, o dirigente da categoria do vestuário a quem Juan Perón enviou a carta referida. A descrição da ação contra Vandor foi publicada em 1974 no periódico El Descamisado. 
A segunda parte, La evidencia, começa com o capítulo La policía destruye la prueba. O primeiro parágrafo é o registro da fala do cortador de pizza de La Real:

- Pero, ¿cómo van a hacer eso? -exclamó el cortador de pizza Carlos Sánchez al ver que los primeros baldazos caían sobre el piso ensangrentado de La Real. ¡No hay que tocar nada! (p. 49)

autor utiliza aqui um recurso muito freqüente nos seus textos. $\mathrm{O}$ de convocar as vozes de terceiros na disputa, utilizado na Carta a mis amigos, por exemplo, na qual a morte de sua filha é contada pela voz de um soldado que participou do cerco que atacou a casa onde ela se encontrava. Para este recurso Ricardo Piglia chama a atenção em La ficción paranoica:

Esa capacidad que no está en el centro siempre, sino de ser discreto respecto a lo que está pasando. Hacer que el lenguaje tenga lugar para otro, esto sería. Hacer en el lenguaje un lugar para que el otro pueda hablar de esa experiencia. Esto me parece que tiene mucho que ver con esa virtud o esas propuestas que la literatura puede proponernos para el futuro. La literatura sería una experiencia en la que el que habla no habla solo. La literatura sería un lugar en el que habla es siempre otro. Yo soy otro, como decía Rimbaud. Siempre hay otro ahí. Ese otro es el que hay que saber oír para que eso que se cuenta no sea una mera información. ${ }^{85}$

Nesta segunda parte Walsh se ocupa não apenas das provas, mas também do seu ocultamento. Consegue um encontro, um cara a cara entre dois sindicalistas que estavam em bandos opostos: Norberto "Beto" Imbelloni e Rolando Villaflor. O cenário é a casa de Imbelloni, quem, dois anos depois, acusa Vandor:

85 PIGLIA, Ricardo. La ficción paranoica. Buenos Aires: Universidad de las Madres de Plaza de Mayo, I Seminario de Análisis Crítico de la realidad argentina 1984-1999, 25 set. 1999 (informação verbal). 
I. - Lo de Rosendo, me lo dice cuatro veces que es una pistola 45 que lo mató. Ahí se deschavó solo Vandor de que fue el revólver de él el que lo mató. Si no, ¿por qué me insiste? Porque el hombre de la duda era yo, si la misma noche me llama para decirme cómo él había visto la pelea, y para decirme, incluso, después cuando lo estábamos velando, que apareció con un croquis diciendo que todos los tiros estaban contra el lugar donde estábamos nosotros sentados.

P. - No hay ningún tiro contra ustedes. En la zona de ustedes, ni un solo tiro.

I. - Por eso. Y ahí me avivo yo. Porque Vandor sabe que yo sé que él lo mató. (p. 121)

Anos depois, na entrevista a Arrosagaray, Rolando Villaflor explica que Walsh encontrou um subterfúgio para marcar o encontro com Imbelloni. Disse a ele que acabava de chegar de Madri junto com Rolando Villaflor e que Juan Domingo Perón, "El Viejo", como era chamado, queria saber toda a verdade sobre o que havia acontecido. Isto não era verdade. E era uma ação muito arriscada. Contavam-se três mortos e muitos feridos naquele episódio e Imbelloni os recebeu rodeado por alguns guarda-costas, mas acreditou. Precisava convencer a Perón da sua própria inocência nas mortes. Rolando Villaflor confirmou frente a Walsh e Imbelloni que eles dois, Villaflor e Imbelloni, tinham brigado aos socos na pizzaria. Isto é, Imbelloni não estava armado. Ainda quando saíram da casa, Rolando e o jornalista temeram uma emboscada. Mas interessava à testemunha que a informação chegasse a Juan Domingo Perón. A narrativa de Walsh era verossímil, como deve ser verossímil uma operação de inteligência e contra-inteligência para ser eficaz.

A terceira parte, El vandorismo, é uma descrição do surgimento de uma camada burocrática nos sindicatos. Uma camada com interesses econômicos particulares bem definidos, que, além do mais, investia em 
diferentes negócios como a quiniela ${ }^{87}$ e a venda de ferro velho.

O texto entremeia a narração com testemunhos dos personagens em itálico, incluindo reconstruções de diálogos. São entrevistadas testemunhas de ambos grupos, até algum tempo atrás, companheiros de lutas. É inserido um croquis para reconstruir a cena da morte de Rosendo.

O registro pula do jargão judiciário ou policial para um tom exageradamente coloquial com evidente efeito irônico. Chega a chamar o sindicalista assassinado de "finadito" (p. 24). Esta escolha era bastante arriscada para as intenções de Walsh e sua equipe, já que amorte de um quadro sindical, vinculado a um grupo que antes havia levado adiante greves e mobilizações, não podia ser observada, imediatamente, senão como um ataque ao conjunto da classe trabalhadora. Ironias sobre o falecido podiam ser lidas como mais uma afronta ao movimento operário. Os companheiros do falecido, porém, não acusavam os patrões, nem a polícia. Ao contrário, eles se uniam à polícia e aos patrões na condenação a militantes sindicais combativos. A ousadia de Walsh baseava-se na possibilidade de sondar rapidamente a recepção nos locais de trabalho, graças à rede de correspondentes constituída pelos portadores do semanário que, além de dar um retorno imediato sobre a leitura de cada reportagem, eram, de alguma maneira, os seus "explicadores" perante os leitores, que neles confiavam e os reconheciam como seus companheiros.

86 "P." é Walsh, o "periodista", e "I." é Imbelloni.

87 Equivalente ao jogo do bicho. Esta atividade patrocinava, inclusive, a atividade do sindicato dos metalúrgicos desde que começou a administração de Vandor e estava a cargo do próprio Rosendo García. 
O foco num acontecimento sem importância do ponto de vista da grande imprensa era a possibilidade de observar um processo que se desenvolvia no seio do movimento sindical. Justamente, a última parte de ¿Quién mató a Rosendo? é um estudo histórico e sociológico sobre a ascensão de uma burocracia sindical com pólo na categoria metalúrgica, que utilizava métodos próprios dos gangsters para se livrar dos quadros combativos e negociar as lutas com os patrões. $O$ reconhecimento desse processo era fundamental para preparar a ruptura com os "antigos" companheiros, atraindo para o novo pólo combativo a maior quantidade de quadros. Para isso, era preciso provar que não se tratava de uma luta "de aparato", e sim de um prolongamento da luta contra a violência de Estado, que cooptava os "velhos companheiros" para melhor operar. O abandono das relações de solidariedade dentro do grupo sindical cooptado era o primeiro sinal de sua degradação: resolviam as pendências a tiros. Algumas testemunhas do grupo de Vandor acreditavam sinceramente na versão do assassino. Mas o testemunho de Imbelloni foi fundamental, não porque fosse uma prova objetiva, mas pelo efeito moral que a confissão de um membro da equipe de Vandor tinha.

Assim como em Operación Masacre e em Caso Satanowsky, o acontecimento que dispara a investigação de ¿Quién mató a Rosendo? era secundário. A investigação de Walsh e a sua escrita o colocaram no centro das atenções. E, por ser um acontecimento secundário, o assassinato de um sindicalista de pouca relevância para o grande público, podia ser observado 
como um indício, um ponto de transparência que permite enxergar na opacidade das relações de poder entre o sindicalismo, o empresariado e o Estado.

A estrutura tripartite de ¿Quién mató a Rosendo? mistura, na primeira parte, a descrição do espaço e dos personagens. Diferencia-se da ordenação de Sarmiento em Facundo, ensaio no qual a geografia é quase que natureza pura e os tipos humanos são apresentados quase como uma continuidade da descrição zoológica. A geografia da primeira parte de ¿Quién mató a Rosendo? é a de um espaço humanizado, urbano, industrial, e os homens são resultado de uma história que se confunde com a história da industrialização.

Mas há uma possível leitura do Facundo que pode nos remeter a ¿Quién mató a Rosendo?. Na última parte do ensaio de Sarmiento, há uma indicação sobre o possível mandante do assassinato de Facundo Quiroga: Juan Manuel de Rosas, que aparecia como seu aliado e acusava seus inimigos políticos, os "salvajes unitarios", pela morte do caudilho do interior. Nesse sentido, há uma simetria com o assassinato de Rosendo por Vandor. Este também se livra de um aliado que atrapalha seus planos e aproveita para atribuir o crime àqueles que enxerga como ínimigos declarados.

A relação de Walsh com a CGT de los Argentinos e a sua atividade no periódico CGT tiveram grande influência sobre seu texto. Arrosagaray, em Rodolfo Walsh, de dramaturgo a guerrillero, diz: 
Decíamos que la relación de Walsh con la CGT de los Argentinos tuvo un peso distintivo en su vida. Su trabajo dentro de la CGT opositora le brindó mil matices nuevos a su vida, sobre todo el de formar parte de un contingente principalmente obrero, contra una dictadura militar y jugando un franco y fuerte rol de agitador. No desde la barricada sino desde la "cocina" propagandística ongarista. Aquí tuvo la posibilidad de elaborar políticas de agitación para lo que estudió mucho la realidad económica y social en busca de que su agitación tuviera un contenido sólido -toda su personalidad y sus concepciones lo empujaron a no ser un mero "panfletario"- y al mismo tiempo, tuviera la suficiente claridad como para ser entendido por decenas de miles de hombres y de mujeres con poca instrucción educativa clásica. Deducimos que la combinación de ambos factores -la profundidad y la claridadpretendía una sola cosa: construir argumentos, posturas y consignas que le sirvieran a la clase obrera para vencer en sus conflictos, desde los más pequeños y cotidianos, hasta los que tenían que ver con el poder político. ${ }^{88}$

\title{
A poética da investigação e da escrita
}

No conto La máquina del bien y del mal, Walsh imagina um mecânico de bairro e o seu amigo querendo passar a perna numa velha para ganhar algum dinheiro. A velha economiza para comprar uma "máquina do Bem e do Mal", capaz de fazer bem ou mal às pessoas. Os dois trapaceiros não esperam, claro, construir uma máquina eficiente, e sim uma geringonça de aspecto convincente, para enganar a velha. A surpresa é que a máquina funciona, para além ou, talvez, por causa dessa sua aparência convincente.

\begin{abstract}
Ahora digan ustedes si no es mala leche. Haber inventado la Máquina del Bien y del Mal y no acordarme cómo hice. Porque he reventado pilas de motores al divino cuete y nunca más sentí esa voz que me decía esa biela aquí y esa válvula más allá. Digan, melones, si con una máquina como ésa yo no estaría lleno de guita y qué necesidad tendría de estar hablando con ustedes. ${ }^{89}$
\end{abstract}

88 ARROSAGARAY, Enrique. Rodolfo Walsh, de dramaturgo a guerrillero. Buenos Aires: Catálogos, 2006, p. 60.

89 WALSH, Rodolfo."La máquina del bien y del mal". In: LUGONES, Pirí (org.). Los diez mandamientos. Buenos Aires: Jorge Álvarez, 1966, p. 14-15. 
Walsh queria construir uma máquina capaz de criar sentido, uma máquina narrativa que, pela sua capacidade de tornar o enredo crível, fosse eficaz para operar no terreno político. A própria palavra "operação", tão cara a Walsh, é tirada do jargão militar, mas também amplamente utilizada no jornalismo para designar a ação que constrói credibilidade para uma ou várias notícias.

Penso que a chave de compreensão da poética da trilogia de investigação de Walsh deve ser procurada nas relações entre o "poder", o "saber" e a "verdade", no sentido que dá Foucault a essas categorias.

\begin{abstract}
Ahora bien, lo que los intelectuales han descubierto después de la avalancha reciente, es que las masas no tienen necesidad de ellos para saber; saben claramente, perfectamente, mucho mejor que ellos; y lo afirman extremamente bien. Pero existe un sistema de poder que obstaculiza, que prohíbe, que invalida ese discurso y ese saber. Poder que no está solamente en las instancias superiores de la censura, sino que se hunde más profundamente, más sutilmente en toda la malla de la sociedad. Ellos mismos, intelectuales, forman parte de ese sistema de poder, la idea de que son los agentes de la 'conciencia' y del discurso pertenece a este sistema. El papel del intelectual no es el de situarse 'un poco en avance o un poco al margen' para decir la muda verdad de todos; es ante todo luchar contra las formas de poder allí donde éste es a la vez el objeto y el instrumento: en el orden del 'saber', de la 'verdad', de la 'conciencia', del 'discurso'. 90
\end{abstract}

A destruição do discurso hegemônico, pela apresentação das "evidências", é um esforço para construir uma "verdade" que é, também, uma verdade partidária. É partidária de um partido que toma forma na medida em que essa "verdade" é formulada. Por esse motivo, a poética de Walsh não é apenas uma poética da escrita e nem da ação, e sim uma poética da relação

90 FOUCAULT, Michel. "Los intelectuales y el poder". In: Microfísica del poder. Trad. 
entre escrita e ação. E não pode ser entendida sem um estudo que contemple a produção, a circulação e a recepção dos textos. Não porque o estudo da forma seja supérfluo, mas porque os sentidos que a forma vai construindo operam dentro desse contexto em permanente mutação. Uma mutação também operada pelo texto e a ação política.

Parece que o grande tema da trilogia é a procura da verdade. Não a verdade como uma coisa dada, mas que precisa ser construída. Na sua conferência La ficción paranoica, Ricardo Piglia diz:

\begin{abstract}
Pero a la vez en Walsh el relato de no-ficción avanza hacia la verdad y la reconstruye desde una posición política bien definida. Esa reconstrucción supone una posición nítida en el plano social, supone una concepción clara de las relaciones entre verdad y lucha social. En este sentido, los libros de no-ficción de Walsh se distancian de la versión más neutra del género tal como se practica en los Estados Unidos a partir de Capote, Mailer y lo que se ha llamado el "nuevo periodismo". En Walsh obviamente el acceso a la verdad está trabado por la lucha política, por la desigualdad social, por las relaciones de poder y por la estrategia del Estado. Una noción de verdad que escapa a la evidencia inmediata, que supone, primero, desmontar las construcciones del poder y sus fuerzas ficticias y, por otro lado, rescatar las verdades fragmentarias, las alegorías y los relatos sociales.
\end{abstract}

Esta verdad social es algo que se tematiza y se busca, que se ha perdido, por lo cual se lucha, que se construye y se registra. La verdad es un relato que otro cuenta. Un relato parcial, fragmentario, incierto, falso también, que debe ser ajustado con otras versiones y otras historias. Me parece que esta noción de la verdad como horizonte político y objeto de lucha podría ser nuestra primera propuesta para el próximo milenio. Existe una verdad de la historia y esa verdad no es directa, no es algo dado, surge de la lucha y de la confrontación y de las relaciones de poder. ${ }^{91}$

Em entrevista publicada na revista Siete Dias, em 1969, Walsh reflete sobre a trilogia e sobre o gênero do romance:

Julia Varela e Fernando Álvarez-Uría. $3^{a}$. Edição. Madrid: La Piqueta, 1992, p. 79.

91 PIGLIA, Ricardo. La ficción paranoica. Buenos Aires: Universidad de las Madres de Plaza de Mayo, I Seminario de Análisis Crítico de la realidad argentina 1984-1999, 25 set. 1999 (informação verbal). 
De alguna manera, una novela sería algo así como una representación de los hechos, y yo prefiero su simple presentación. Además uno no escribe una novela sino que está dentro de ella, es un personaje más y la está viviendo. A mí me parece que los fusilamientos y la muerte de García tienen más valor literario cuando son representados periodísticamente que cuando se los traduce a esa segunda instancia que es el sistema de la novela. ${ }^{92}$

Walsh está convencido, em 1969, que a forma do "romance tradicional" era insuficiente para seus objetivos político-literários. Já não se trata apenas de tomar distância do gênero policial, mas também do romance tradicional, uma vez que o romance tradicional pretende dar conta da totalidade, uma totalidade dada a priori, a tarefa da sua literatura é a procura de uma verdade que se compõe a partir dos testemunhos fragmentários, das pequenas histórias pessoais. Essa convicção de Walsh vai se afirmando ao longo dos anos pela experiência das investigações e do comprometimento político. Ele reconhece, na mesma entrevista a Siete Dias:

- ¿Cómo se definiría ideológicamente?

- Evidentemente, tengo que decir que soy marxista, pero un mal marxista porque leo muy poco: no tengo tiempo para formarme ideológicamente. Mi cultura política es más bien empírica que abstracta. Prefiero extraer mis datos de la experiencia cotidiana: me interno lo más profundamente que puedo en la calle, en la realidad, y luego cotejo esa información con algunos ejes ideológicos que creo tener bastante claros. ${ }^{93}$

E mais adiante:

¿Por qué empleó técnicas distintas en sus libros "periodísticos"?

- En Operación Masacre yo libraba una batalla periodística "como

92 WALSH, Rodolfo. "Lobo estás?". In: Ese hombre y otros papeles personales. Buenos Aires: de la Flor, 2007, p. 142-143.

93 WALSH, Rodolfo. "Lobo estás?". In: Ese hombre y otros papeles personales. Ed. cit., p. 142. 
si" existiera la justicia, el castigo, la inviolabilidad de la persona humana. Renuncié al encuadre histórico al menos parcialmente. Eso no era únicamente una viveza; respondía en parte a mis ambigüedades políticas. ¿Quién mató a Rosendo?, en cambio, es una impugnación absoluta del sistema y corresponde a otra etapa de formación política. ${ }^{94}$

As modificações formais, porém, não são resultado de uma convicção política diferente em diferentes momentos da atividade literária do autor. Antes, essas convicções são resultado de uma praxis político-literária na qual a eficácia dessas modificações formais era testada permanentemente pelos seus efeitos práticos na disputa pela hegemonia das narrativas.

A responsabilidade política que recaía sobre a obra investigativa não deixava, porém, muita margem para a experimentação. Creio que eram os contos, examinados a seguir, os textos privilegiados para realizar essa experimentação.

94 WALSH, Rodolfo. "Lobo estás?". In: Ese hombre y otros papeles personales. Ed. cit., p. 144. 


\section{Capítulo 3: Literatura:}

\section{“un avance laborioso a través de la propia estupidez"95}

Se os relatos policiais da primeira fase de Walsh foram escritos, segundo o próprio autor, pensando em "diversão e dinheiro"96 os da segunda fase correspondem a um interesse literário. Eles se apresentam na forma breve do conto. Muitos outros textos do autor podem ser agrupados dentro dessa categoria e intencionalidade, coincidindo com o período de produção dos contos policiais da segunda fase. Esse corpus abrange obras publicadas entre 1952 e 1969 e constitui aquilo que poderíamos chamar de "obra literária de Walsh", aquilo que ele considerava literatura num sentido mais estrito e que, a partir de 1969, ele deixou de publicar.

Os motivos desse abandono estão relacionados com a discussão que foi iniciada na década de 60 a propósito do intelectual-escritor e do intelectual-militante, no contexto das tensões geradas pela revolução cubana no seio do campo intelectual da esquerda latino-americana, estudadas por Claudia Gilman em Entre la pluma y el fusil. Debates y dilemas del escritor revolucionario en América Latina. Esse debate foi, de alguma maneira, uma reedição do dilema cervantino plasmado no capítulo Que trata del curioso

95 Definição da literatura pelo autor em WALSH, Rodolfo. "El violento oficio de escritor". In: BASCHETTI, Roberto. Rodolfo Walsh, vivo. Buenos Aires: de la Flor, 1994, p. 32.

96 WALSH, Rodolfo. "El violento oficio de escritor". In: BASCHETTI, Roberto. Rodolfo Walsh, vivo. Ed. cit., p. 30-32. 
discurso que hizo don Quijote de las armas y las letras ${ }^{97}$. A militância era pensada por grande parte dos intelectuais envolvidos no debate como sinônimo da ação guerrilheira.

Em Walsh, esta discussão adquiria um teor diferenciado, em primeiro lugar, porque ele não partilhava das premissas foquistas e, em segundo lugar, porque ele imaginava para si um tipo de militância que incluía as tarefas da escrita.

Em 1969, durante um debate sobre a literatura argentina realizado em La Habana, coordenado por Mario Benedetti e com participação de Francisco "Paco" Urondo e Juan Carlos Portantiero, referindo-se aos escritores argentinos do século XIX, Walsh disse:

[...] el escritor es casi siempre otra cosa; es casi siempre, además de un escritor, primordialmente un político, un hombre de acción.

La actividad literaria era considerada como una cosa accesoria. Ninguno de ellos prácticamente se dedicaba con exclusividad a eso. El literato profesional nace después, a veces viene del periodismo, como Payró. [...]

Este cambio es importante y señala probablemente un cambio también en la actitud. En la medida en que los escritores eran también protagonistas de la acción, en la medida también en que el país crecía y se abrigaban unas enormes esperanzas acerca del desarrollo futuro del país (prácticamente no había límites señalados para ese crecimiento), eran terriblemente optimistas.

Esa situación cambia para los primeros escritores profesionales: el caso de Roberto Payró, que es un novelista, un cuentista, y hace periodismo, con actitudes magníficas con respecto a todos los problemas. ${ }^{98}$

97 CERVANTES, Miguel de. "Que trata del curioso discurso que hizo don Quijote de las armas y las letras". In: El ingenioso hidalgo don Quijote de La Mancha. Buenos Aires: Planeta, 2000, p. 410-414.

98 PORTANTIERO, Juan Carlos; URONDO, Francisco e WALSH, Rodolfo. "La literatura argentina del siglo XX". In: BASCHETTI, Roberto (org.). Rodolfo Walsh, vivo. Buenos Aires: de la Flor, 1994, p. 34. 
Provavelmente, Walsh pensava que se repetiam as condições que favoreciam, depois da revolução cubana, o otimismo ativo dos intelectuais.

Mas isso não implicava o abandono da literatura. Antes implicava uma modificação ou uma ampliação do conceito e da maneira de fazer literatura, como o autor explicitou em entrevista concedida em março de 1970 a Ricardo Piglia. Suas respostas, porém não supõem uma opinião definitiva e sim uma problematização da questão.

Por um lado, ele apresentava a discussão sobre a vigência do romance como forma literária, em contraposição a obras como Biografia de un cimarrón, de Barnet, ou mesmo seu ¿Quién mató a Rosendo?, obras que experimentavam com novas formas discursivas e nas quais a inclusão das vozes dos não letrados abalavam o conceito de autoria individual. Mas, apesar dessas considerações, Walsh não desprezava de antemão as velhas formas:

[...] lo que yo dije antes no debe tomarse como un descarte aislado de las formas literarias tradicionales de la novela, del cuento, para reemplazarlos siempre y definitivamente por el testimonio, pero sí pienso que va a haber que usar esas formas de otra manera. Pienso que ya no se van a poder usar inocentemente con una serie de convenciones que prácticamente ponen toda la historia en el Limbo. $^{99}$

Em todo caso, naquela época, Walsh tinha adquirido uma convicção, já fora do que ele chamava de "concepto burguês de literatura":

99 WALSH, Rodolfo. "Hoy es imposible en la Argentina hacer literatura desvinculada de la política". In: BASCHETTI, Roberto. Rodolfo Walsh, vivo. Ed. Cit, p. 70. 
[...] te das cuenta de que tenés un arma: la máquina de escribir. Según como la manejas, es un abanico o es una pistola, y podes utilizarla para producir resultados tangibles, y no me refiero a los resultados espectaculares, como es el caso de Rosendo ${ }^{100}$, porque es una cosa muy rara que nadie se la puede proponer como meta, ni yo me lo propuse, pero con la máquina de escribir y un papel podés mover a la gente en grado incalculable. No tengo la menor duda. ${ }^{101}$

Walsh manifestou esta conclusão já no período em que havia deixado de publicar o que ele entendia por literatura no sentido estrito. Porém, a tensão entre ser um escritor de ficção que assina seus escritos e abandonar radicalmente a publicação de ficção e diluir sua condição de autor iria acompanhá-lo até o dia do seu desaparecimento, como veremos. Nos seus Papeles personales registrou:

Cómo volver a escribir. ${ }^{102}$

[Cómo] sentir que mi libro también sirve, romper la disociación que en todos nosotros están produciendo las ideas revolucionarias, el desgarramiento, la perplejidad entre la acción y el pensamiento ... (p. 92)

La política se ha reimplantado violentamente en mi vida. Pero eso destruye en gran parte mi proyecto anterior, el ascético gozo de la creación literaria aislada ... (p. 93)

[...] renunciar a todas las canchereadas, elipsis, guiñadas a los entendidos ... Escribir para todos. (p. 150)

[T] hings began to change in 1968, when politics took all the field. Then I started to be a political writer. (p. 170)

You stopped being a writer in 1969, when Rosendo was published, or in 1967, after Un kilo de oro? That's an important question. (p. 170)

You still want to be a writer ... (p. 176)

100 Refere-se a ¿Quién mató a Rosendo?, já citado.

101 WALSH, Rodolfo. "Hoy es imposible en la Argentina hacer literatura desvinculada de la política". In: BASCHETTI, Roberto. Rodolfo Walsh, vivo. Ed. Cit, p. 73-74.

102 WALSH, Rodolfo. "Papeles personales". In: Ese hombre y otros papeles personales. Buenos Aires: Seix Barral, 1996, p. 71. Neste texto, Walsh intercala escrita em castelhano e em inglês. Neste capítulo, as referências a "Papeles personales" que aparecem a seguir indicam as páginas desta edição. 
In fact my writing habits began to fade away in 1967, when I undertook the novel. That year I only finished a short story. But things really began to change in 1968, when politics took all the field. Then I started to be a political writer . (p. 176-177)

[Escribir] una ficción que incorpore la experiencia política. (p. 178)

[...] lo que importa es el proceso que ha pasado por mí la historia de cómo yo cambié y cambiaron los demás y cambió el país. (p. 198)

¿qué hago con todo eso? Empiezo a juntarlo y empiezo a mirarlo empiezo a estudiarlo empiezo a ver si se deja escribir . (p. 199)

[la política me lleva a] desvaloriza[r] consciente o inconscientemente, el trabajo literario. (p. 202)

Mi relación con la literatura se da en dos etapas: de sobrevaloración y mitificación hasta 1967, cuando ya tengo publicados dos libros de cuentos y empezaba una novela; de desvalorización y paulatino rechazo a partir de 1968, cuando la tarea política se vuelve una alternativa. (p. 205)

Sabemos, por testemunho da sua companheira, Lilia Ferreira, que, embora Walsh tenha deixado de publicar contos em 1969, continuou escrevendo-os e preparando a "novela séria" ou "novela geológica", "por camadas", que imaginava. Também sabemos, por Lilia Ferreyra ${ }^{103}$, que nos últimos tempos tinha desistido dela e estava desdobrando o material.

Penso que seus contos, publicados ou não, eram um espaço de experimentação e de reflexão sobre procedimentos de escrita e sobre representação da história e da ação política. Por esse motivo, não considero esses contos alheios à sua escrita militante, e sim parte dela. Mas uma parte específica, em que a falta de uma exigência imediata, de uma convocação imediata para a ação permitia fazer da forma adotada um método de conhecimento e de representação e um meio de expressão da sua visão de mundo e do próprio papel que Walsh se atribuía. De outro modo, podemos

103 FERREYRA, Lilia. "Dos lectores". Jornal Página/12, Buenos Aires, 9/jan./2006, contracapa. Disponível em: < http://www.pagina12.com.ar/diario/contratapa/13-61457-2006- 
enxergar nessa produção um metadiscurso sobre sua ação como escritor militante.

Passo agora a estudar alguns desses contos: Los ojos del traidor, La máquina del bien y del mal, Nota al pie, Imaginaria e Esa mujer. Farei também um comentário mais geral sobre o conjunto de contos sobre 0 internato para irlandeses, conhecido como "série dos irlandeses". A seleção espera dar conta de uma série procedimentos empregados em mais de um conto que eventualmente migravam para outros textos do autor e de temas que perpassam toda a sua obra, mas que é nos contos que Walsh consegue tratar com um distanciamento que favorece a reflexão.

\section{Los ojos del traidor}

\section{Como narrar a violência?}

Já no terceiro conto publicado, em 1952, Los ojos del traidor, compilado depois junto com relatos policiais, apesar de não ser exatamente um conto desse tipo, senão de ficção científica ou talvez um conto estranho, Walsh problematiza o testemunho. O tema lida com questões hoje em voga sobre possibilidades e limites do ato de narrar a violência, discussões sobre a testemunha integral ${ }^{104}$.

No enredo do conto de Walsh, um condenado à morte doa seus olhos

01-09.html>. Acesso em: 28 out. 2008 às 18:08.

104 Segundo Giorgio Agambem, a testemunha integral justamente não pode testemunhar, porque a violência a destruiu. Ver: AGAMBEN, Giorgio. "EI testigo" e "EI 'musulmán'”. In: Lo que queda de Auschwitz. El archivo y el testigo. Homo Saccer III. Trad. 
para transplante após o seu fuzilamento. Só pelo título sabemos que foi acusado de traição. A narração é em primeira pessoa pelo oftalmologista que realiza os transplantes de córnea. O tempo da narrativa coloca os fatos no passado, na Hungria, imediatamente depois da Segunda Guerra, antes de o personagem narrador ter sido expatriado, vítima de intrigas, segundo ele diz. O transplantado "nega-se" a ver. Uma nota de rodapé comenta, também em primeira pessoa e à maneira de um relatório clínico, a suspeita do narrador de um fator psicológico ter contribuído para a cegueira do paciente. Ele passa a ter pesadelos e alucinações e entra em depressão profunda. Aos poucos, a imagem do fuzilamento vai se definindo nas suas visões, tal como o havia presenciado o dono original das suas novas córneas.

Na hora da cirurgia, o oftalmologista tinha constatado o olhar surpreso do executado: "Tenía las pupilas dilatadas en un vago asombro" ${ }^{105}$. E, dois parágrafos antes, o narrador/oftalmologista dizia: "Pensé, ociosamente, que el ejecutado podía ser yo, que el destino era absurdo, que la muerte era una costumbre trivial“ (p. 171). Há, nesta seqüência, um jogo de identificações, de compaixão entre o médico e o doador, mas que só toma forma concreta no paciente transplantado. É ele quem se recusa a ver "sua própria" morte, inocente, como o narrador insinua que era o doador.

A conexão com Livraga, o fusilado que vive de Operación Masacre, estudada no capítulo 2, é imediata. O personagem improvável capaz de

Antonio Gimeno Cuspinera. Valencia: Pre-Textos, 2000, p. 13-40 e 41-90.

105 WALSH, Rodolfo. "Los ojos del traidor". In: WALSH, Rodolfo. Cuento para tahúres y otros relatos policiales. 3a ${ }^{a}$. Ed. Buenos Aires: de la Flor, 1999, p. 171. Neste capítulo, as referências a "Los ojos del traidor" que aparecem a seguir indicam as páginas desta edição. 
relatar seu próprio fuzilamento em primeira pessoa se fez carne na testemunha Livraga, que seria fuzilado quatro anos depois da publicação do conto Los ojos del traidor e sobreviveria para contar "sua morte".

Antecipação? Prefiro pensar que a escrita de Los ojos del traidor tornou Walsh mais receptivo ao testemunho de Livraga, e essa receptividade foi depois reforçada pela morte do recruta junto à janela da casa do autor, na mesma noite do fuzilamento.

No sé qué es lo que consigue atraerme en esa historia difusa, lejana, erizada de improbabilidades. No sé por qué pido hablar con ese hombre, por qué estoy hablando con Juan Carlos Livraga.

Pero después sé. Miro esa cara, el agujero más grande en la garganta, la boca quebrada y los ojos donde se ha quedado flotando una sombra de muerte. Me siento insultado, como me sentí sin saberlo cuando oí aquel grito desgarrador detrás de la persiana.

Así nace aquella investigación, este libro. ${ }^{106}$

Há um deslocamento. Os olhos de Livraga trazem para o autor um sentimento difuso de vergonha. A vergonha é por Livraga, mas também pela morte do "conscripto", que combatia a favor do governo e não do levantamento $^{107}$. Esse sentimento difuso, decorrente, também, do seu apoio ao governo, com o qual o soldado morto não cultiva qualquer adesão e que

106 WALSH, Rodolfo. Operación masacre. Ed. cit., p. 19.

107 Depois, o "soldadito" apareceria novamente. No conto Imaginaria, na peça de teatro La granada e na Carta a mis amigos. Em todos os casos, o "soldadito" é o portador involuntário de uma revelação. Ele está aí porque é obrigado, convocado independentemente da sua vontade. Ele não tem bando, ele está num bando. Por esse motivo, sua morte não tem um sentido subjetivo. Sua morte o surpreende porque não é conseqüência de uma opção pessoal e sim do lugar no qual o colocaram.Por isso, a morte do soldado é emblemática. Sua condição é a da vítima. Cada edição de Operación Masacre porta na capa, como ilustração, uma reprodução de Os fuzilamentos de la Moncloa, de Francisco Goya. No quadro, o fuzilado encara o pelotão com olhar perplexo, como deslocamento do olhar do soldado Bernardino Rodríguez para o do testemunha Livraga.Mas o "soldadito" é também quem traz uma informação veraz até então ocultada. E é veraz por ele ser ou a vítima integral ou o terceiro no conflito. Isto é, aquele que está aí obrigado, mas não pertence estritamente a um bando. 
fuzilou ilegalmente, naquela mesma noite, treze civis "inocentes" do levantamento, apenas "culpados" por serem pobres e peronistas.

Suspeito que havia em Walsh uma tensão entre ganhar dinheiro e se tornar famoso às custas dos fuzilados de 1956 e denunciar o crime. Como uma reparação que ele, o autor, devia àquele "soldadito" morto sem convicção, a quem Walsh, partidário do governo, não socorreu em tempo. Essa contradição está instalada bem antes do debate sobre a "trampa cultural", entre os intelectuais do "boom", auspiciado pela Casa das Américas e descrito por Gilman, no seu texto já mencionado.

Los ojos del traidor, de 1952, também foi posterior à publicação, em 1944, de Tema del traidor y el héroe de Jorge Luis Borges. Era certo que Walsh conhecia o texto de Borges e penso que o comenta ao escrever o seu próprio conto. Há outro dado: irishness de Walsh não podia deixar de ser tocada pelo conto de Borges.

No enredo de Tema del traidor y el héroe, Ryan, historiador, em 1914, investiga a vida de Fergus Kilpatrick, herói das jornadas de 1824 na Irlanda. Suas pesquisas o levam a James Nolan, encarregado por Kilpatrick de descobrir um traidor no grupo de conspiradores. Nolan descobre que o traidor é o próprio Kilpatrick, mas a revelação pode comprometer o levantamento que preparam. Os conspiradores aceitam o plano de Nolan, que propõe uma morte heróica para o traidor que aumente a moral dos patriotas. O próprio 
Kilpatrick aceita participar do plano para se redimir. O atentado é precedido de presságios e acontece durante uma apresentação de teatro, duplicando especularmente o artifício. Nolan, tradutor de Shakespeare, deu ao seu plano de inteligência contornos trágicos, com detalhes tirados de Macbeth e Julio César. Kilpatrick morre nas vésperas do levantamento e fica na memória do seu povo como herói de Irlanda. O historiador Ryan percebe-se, ele também, parte da trama de Nolan e opta por consagrar Kilpatrick como herói nacional na obra historiográfica que vem elaborando.

O tema de Borges não é apenas o do traidor e do herói, mas o da força da literatura para construir sentidos. Um eficiente trabalho de inteligência equipara-se com a boa literatura. É o que parece dizer o autor. E Walsh não podia deixar de reparar nesta questão em 1952, com um acréscimo reflexivo a propósito da Segunda Guerra.

A morte do tio de Walsh na batalha de Salónica, à qual me referi no capítulo 2, sem dúvida, deve ter feito nosso autor refletir sobre Tema del traidor y el héroe. Afinal: quem é traidor e quem é herói? A morte a todos iguala na sua condição de humanos e mortais. O tio Willy podia ter morrido num ou no outro bando, tanto fazia. Nem sabia direito, ao partir de Buenos Aires, qual era o "bando certo". Essa reflexão subjaz nas entrelinhas de Los ojos del traidor.

Suspeito que esse complexo de temas de reflexão, que tocavam fundo na sua identidade familiar, estava presente na investigação e escrita de 
Operación Masacre, na construção da sua poética. E permaneceram ao longo da vida de Walsh, a ponto de projetar a escrita do conto Meu tio Willy, que ganó la guerra do qual falarei ao tratar da série dos irlandeses, ainda neste capítulo.

Los ojos del traidor é, também, uma problematização sobre o ponto de vista. A metáfora das córneas transplantadas põe em questão a dificuldade de narrar a violência, dificuldade com a qual o autor se enfrentaria quatro anos após a publicação do conto.

\section{La máquina del bien y del mal}

\section{A escrita como um ofício e a captura da voz do não letrado como ato político}

La máquina del bien y del mal é um conto aparentado com Fotos e com Nota al pie, do qual trataremos ainda neste capítulo. A conexão com esses $\operatorname{contos}^{108}$ é a problematização da literatura como "máquina" produtora de sentidos e a possibilidade da sua "fabricação" em "oficinas de fundo de quintal". Uma literatura considerada como um ofício. Assim como o fotógrafo de Fotos ou o tradutor de Nota al pie, os mecânicos de La máquina del bien y del mal são também criadores, artistas, poetas. Como Walsh, esses mecânicos criam uma máquina que escapa às suas intenções iniciais.

108 O primeiro foi escrito anteriormente. Quanto ao segundo, não se pode precisar a data de sua composição. 
Walsh metaforiza o processo pelo qual ele próprio se tornou escritor, sua passagem do exercício de um ofício para a arte. A "Máquina" do conto não é mais do que a máquina literária que ele construiu. No conto, um mecânico espertalhão constrói um aparelho para enganar uma velha incauta, vendendo-o para ela como instrumento capaz de fazer o bem ou o mal para as pessoas.

En el fondo siempre he sido un artista. No se rían, melones, si al final yo mismo no sabía lo que estaba haciendo. Era una especie de inspiración divina que me agarraba y me decía poné esta válvula acá y este buje más allá y acortale el cigüeñal. Cada mañana se me ocurrían nuevas ideas y de noche no podía dormir pensando en la Máquina. ${ }^{109}$

O trabalho do mecânico não é senão uma metáfora dos procedimentos literários de Walsh, partindo de fragmentos e recursos argumentativos extraliterários ou tomados das literaturas "menores". Como diz Imperatore: "La máquina hecha a partir de motores en desuso emula procedimentos de construcción que también son artísticos, se trata de selección y montagem“110. Mas o processo de criação artística não é reduzido a esse procedimento mecânico. Entra um elemento de revelação -a inspiração divina- que indica como a seleção e o ordenamento devem ser realizados. Esse elemento age por meio do autor independentemente das suas motivações e objetivos. A máquina, em cuja eficiência o seu criador não acreditava, funciona.

109 WALSH, Rodolfo."La máquina del bien y del mal". In: LUGONES, Pirí (org.). Los diez mandamientos. Ed. cit., p. 10.

110 IMPERATORE, Adriana. "Voces, prácticas y apropiaciones de lo popular en la ficción de Walsh. In: ZUBIETA, Ana M. (comp.): Letrados iletrados. Apropiaciones y representaciones de lo popular en la literatura. Buenos Aires: Eudeba, 1999, p.184. 
Piglia se referirá, em $A$ cidade ausente, àquilo que Walsh metaforiza neste conto, à "máquina de narrar":

Inventar uma máquina é fácil, se a pessoa conseguir modificar as peças de um mecanismo anterior. As possibilidades de transformar aquilo que já existe numa outra coisa são infinitas. ${ }^{111}$

A inteligência do Estado é basicamente um mecanismo técnico destinado a alterar o critério da realidade. É preciso resistir. Nós tentamos construir uma réplica microscópica, uma máquina de defesa feminina, contra as experiências e os experimentos e as mentiras do Estado. ${ }^{112}$

Como Walsh, mas de maneira mais explícita, Piglia tematiza a "máquina de narrar". No enredo de $A$ cidade ausente, à grande "máquina de narrar", que é o Estado, é possível opor máquinas construídas com refugos de motores velhos, desarmados em oficinas de fundo de quintal nos subúrbios das cidades. Elas geram os pequenos relatos fragmentados que podem vir a compor o grande contra-relato. A "máquina do bem e do mal" é um dispositivo "moderno" que substitui a "árvore do bem e do mal" e com ela disputa o grau mais alto na criação: a produção de sentidos. Enfrenta, assim, a naturalização das narrativas hegemônicas pela ação de um trabalho prosaico e terrestre, ao alcance dos plebeus.

A idéia de uma "máquina de narrar" faz parte do repertório temático do sistema literário argentino, já a partir de Macedonio Fernández. A máquina literária de Walsh, assim como a "máquina do bem e do mal" do seu conto, é

111 PIGLIA, Ricardo. A cidade ausente. Trad. Sergio Molina. 2a. Ed. São Paulo: lluminuras, 1997, p. 115. 
capaz de criar sentidos não apenas para os leitores. Ela transformou o próprio Walsh e deu um sentido para a sua própria ação. Ele construiu uma máquina de narrar que ganhou autonomia. Há um momento na biografia político-literária de Walsh em que ele toma consciência disso, o que ocorre após escrever Operación Masacre.

Como o mecânico espertalhão do conto, o autor queria ganhar dinheiro, no caso, com um furo jornalístico. Ele o reconheceu durante um debate na Universidade de Buenos Aires, em 1973: “- Dígame Walsh... ¿qué ideales lo llevaron a escribir Operación Masacre? - ¿ldeales? Yo quería ser famoso... ganar el Pulitzer... tener dinero..."113.

Mas a máquina de narrar histórias criada por Walsh modificou a sua história pessoal, em primeiro lugar, porque a sua produção narrativa foi para ele, também, um método de conhecimento, segundo reconhece em El violento oficio de escritor: "Operación Masacre cambió mi vida. Haciéndola comprendí que, además de mis perplejidades íntimas, existía un amenazante mundo exterior“"114.

Por um lado temos a escrita como um ofício ao alcance de qualquer um, mas capaz de criar sentidos; por outro, o elemento de inspiração irrepetível. A tensão não se resolve. Não há manual ou normativa, como 
parece indicar o título da coletânea na que o conto foi publicado: Los diez mandamientos. O relato do mecânico é o de uma frustração, a de ter construído a máquina produtora de sentidos e não conseguir reproduzi-la.

Mas La máquina del bien y del mal também tem parentesco com Corso, com Las tres noches de Isaías Bloom, com Mensaje a Pérez Griz, entre outras obras, na captura da fala marginal. No conto que estamos examinando, a narração em primeira pessoa, domina todo o conto. Também há uma conexão com Cartas, conto produzido a partir de correspondência achada num arquivo, de um sitiante pobre e endividado. Em Cartas inseremse trechos da correspondência com a sintaxe e a ortografia do sitiante não letrado.

Nestes contos a captura do discurso do outro é radical e está aparentada com procedimentos utilizados por Walsh na sua atividade jornalística. A captura de que falamos coloca-se como uma questão políticoliterária desde a constituição do sistema literário argentino. Já em El matadero $^{115}$, de Esteban Echeverría, a voz do não letrado é apropriada e encapsulada no estilo direto, separada claramente da voz do narrador. A apropriação de uma fala-ação, uma fala que convoca à violência, serve como justificativa paranóica das elites para a violência preventiva contra os pobres. Seguindo a tradição, em La fiesta del monstruo, Borges e Bioy Casares construiriam depois um conto com narração em primeira pessoa pelo protagonista pobre-peronista-violento, no qual esses adjetivos funcionam 
como sinônimos, com efeito tão demonizador quanto o de Echeverría ${ }^{116}$.

Mas na obra literária de Walsh, os procedimentos de inclusão dessa voz viram tema, ora radicalizando o conflito, como em Las tres noches de Isaías Bloom, à maneira do Arlt de Los siete locos, pelo uso de dois registros lingüísticos bem definidos, ora pelo controle discursivo absoluto, como em La máquina del bien y del mal e em Corso, à maneira do Torito de Cortázar.

\section{Nota al pie}

\section{A batalha pelo sentido}

No conto Nota al pie, Walsh utiliza o recurso borgeano de dotar de significado ficcional as notas de rodapé. Ao colocar numa nota de rodapé a carta do tradutor suicida dirigida ao seu chefe, situa espacialmente o texto no lugar social ao qual a fala própria do empregado podia ter acesso.

No espaço gráfico "legitimado" para a literatura, um narrador em terceira pessoa acompanha o chefe nas suas reflexões, nas quais formula dúvidas. Essas dúvidas vão se esclarecendo no texto "subalterno", que cresce na nota de rodapé. Ao mesmo tempo, é pelas reflexões do chefe Otero que temos acesso a vieses da história e da personalidade do tradutor León dos quais ele próprio não tem consciência. O autor não resolve a tensão, ao contrário, deixa-a em suspenso, dando curso à fala do suicida, suprimida no texto "legítimo" pela morte do protagonista. Essa morte é, ao 
mesmo tempo, uma repetição do tratamento da voz popular, típico na Argentina: o popular fala só depois de suprimido.

No conto, a polarização entre um texto e outro exprime a cisão própria da sociedade, a separação entre trabalho manual e intelectual e a alienação fruto do trabalho em tais condições. A construção reserva assim ao autor conhecimento e nega às personagens o acesso a ele. No entanto, ele é também acessível ao leitor.

León, o tradutor, não é um "representante" da classe trabalhadora. Sua história é a de alguém que pretende fugir a uma determinação de classe. Ele está afastado dos seus pares, quis passar de borracheiro a intelectual, sonha com ser escritor e não consegue ser mais que tradutor. Um homem que, para ser, tem de ser outro:

[...] prestar la cabeza a un extraño, y recuperarla cuando está gastada, vacía, sin una idea, inútil para el resto del día. [...] yo alquilaba el alma. Los chinos tienen una expresión para designar a un sirviente. Lo llaman Yung-jen, hombre usado. ${ }^{117}$

León imagina que os trabalhadores manuais, os que foram seus pares, invejam-no por sua posição social, ainda que não tenha mudado sua condição de classe. Como eles, mora mal num quarto de pensão e tem que colocar no penhor sua máquina de escrever, seu instrumento de trabalho, única posse de valor, para comprar medicamentos.

117 WALSH, Rodolfo. "Nota al pie". In: Un kilo de oro. 3a. Edição. Buenos Aires: de la Flor, 1997, p. 94. Neste capítulo, as referências a "Nota al pie" que aparecem a seguir 
É sintomática a escolha do cenário da pensão, o preferido de Arlt no pré-peronismo, habitat de seres solitários, marginais, isolados. Também é sintomática, pelos mesmos motivos, a escolha de um personagem órfão, sem vínculos afetivos com seus pares, sem companheira.

Otero atribui ao funcionário, postumamente, uma excessiva preocupação com a injustiça no mundo, que alimentaria a tristeza de León: "los bombardeos en Vietnam o los negros del Sur" (p. 78). Há aqui um deslocamento: havendo a violência da repressão na segunda metade da década de 50, que envolve massacres como a investigada por Walsh em Operación Masacre, León verbaliza a sua preocupação com uma violência geograficamente distante. Mas essa preocupação não aparece na carta do suicida, como razão para a decisão tomada.

Também há, por parte de Otero, a suspeita de que o morto caçoa dele, como se seu suicídio e sua melancolia Ihe fossem "dedicados", como prenda de ingratidão. No discurso de León, no entanto, há um cuidado excessivo em preservar a relação com o seu chefe: coloca a máquina de escrever no penhor em lugar de pedir um adiantamento, por exemplo, aumentando seu esforço ao ter que escrever à mão.

O recurso aos dois focos narrativos tão claramente definidos é singular na obra de Walsh, que nos primeiros textos não apenas se valia de um 
narrador onisciente, mas que ia além, ao explorar tal condição pela utilização do croquis, das descrições panorâmicas, próprias da tradição do relato épico. Comenta Viñas: "Walsh, mediante sus planos explicativos, inesperadamente incurre en ese ademán. Incluso cuando describe una partida de ajedrez 'vista de arriba'",118.

A tensão produzida pela presença da carta no bolso de Otero, sendo seu conteúdo registrado na nota de rodapé, é exacerbada pelo fato de o chefe recusar sua leitura. A propósito desta questão, Imperatore assinala:

\begin{abstract}
Se produce así una doble negación que torna inapropiada la aparición de la palabra del traductor: por un lado el autor del texto es quien posee la propiedad intelectual y como correlato material, su escritura se expande en toda la página. El traductor no tiene lugar propio, incluso en la ficción, el único texto que escribe -su carta-epitafio- nunca es leído por su destinatario, ya que Otero subestima su contenido y lo presupone. ${ }^{119}$
\end{abstract}

León descobriu que "traducir era asunto distinto de conocer dos idiomas: un tercer dominio, una instancia nueva" (p. 75). A instância à qual nenhum dos personagens tem acesso também é um terceiro domínio diferente da carta e das reflexões de Otero. Essa instância não é apenas a soma dos dois discursos, mas a tensão instalada entre ambos, segundo aponta Imperatore. O autor coloca-se, ele próprio, num lugar externo a ambos os textos Há, porém, uma culpa difusa, assim como a de Otero, que talvez o atinja:

118 VIÑAS, David. "Rodolfo Walsh, el ajedrez y la guerra". El ortiba. Disponível em: $<$ http://www.elortiba.org/walsh.html>. Acesso em: 28 out. 2008 às 16:51.

119 IMPERATORE, Adriana. "Voces, prácticas y apropiaciones de lo popular en la ficción de Walsh. In: ZUBIETA, Ana M. (comp.): Letrados iletrados. Apropiaciones y representaciones de lo popular en la literatura. Ed. cit., p.177. 
[...] nadie puede vivir con los muertos, es preciso matarlos adentro de uno, reducirlos a imagen inocua, para siempre segura en la neutra memoria. Un resorte se mueve, una cortina se cierra, y ya hemos pasado sobre ellos juicio y sentencia, y una suave untura de olvido y perdón. (p. 71)

Parece que Walsh quer se afastar dessa atitude, do esquecimento dos mortos, pelo exercício desta escrita: o conto é dedicado In Memoriam a Alfredo de León, morto em 1954. A editora Hachette havia dado a Walsh o trabalho de terminar a tradução de um livro começada por Alfredo de León, que tinha se suicidado.

Assim como as teclas da Remington, León é um homem usado, um homem gasto. Trocou palavras por dinheiro. Há referências precisas no conto:

Ciento treinta carillas a cien pesos la carilla, son trece mil pesos. ( $p$. 75)

[...] 220 carillas a dos pesos. (p. 89)

[...] En ese tiempo [doze anos] he traducido para la Casa ciento treinta libros de 80.000 palabras a seis letras por palabra. Son sesenta millones de golpes en las teclas. Ahora comprendo que el teclado esté gastado, cada tecla hundida, cada letra borrada. Sesenta millones de golpes son demasiados, aun para una buena Remington. Me miro los dedos con asombro. (p. 96)

Todas as tentativas do protagonista de se aproximar à alta cultura, primero à melhor literatura policial e depois a Coleridge, Keats, Shakespeare, apenas serviram para por em relevo, por um lado, a distância entre sua condição e a dos letrados e, por outro, a solidão daquele que, afastado dos seus pares, fica a meio caminho, com uma noção difusa de carência que nada pode compensar. 
E é pela escrita que Walsh pensa se tornar mais sábio e tenta entender essa carência que a todos atinge. Como assinala em El violento oficio de escritor: "[...] pienso que la literatura es, entre otras cosas, un avance laborioso a través de la propia estupidez“120.

León é um personagem marginal, e não um "tipo", um personagem "representativo" ou "modelar". Também são marginais os fatos narrados.

Porém, estando à margem, por um esforço literário, os acontecimentos relatados revelam sua centralidade. É um esforço por impor um tema que está fora da pauta hegemônica. Este procedimento parece típico em Walsh, na sua obra investigativa. E Piglia, na sua conferência, La ficción paranoica, o apresenta como aspiração para a literatura:

\begin{abstract}
Estamos en un costado. Estamos aquí en un lugar y a menudo no somos nosotros los que ponemos los temas de conversación. Yo digo siempre que en la Argentina, básicamente, hay que cambiar de conversación. Porque, básicamente, me parece que la posición de los sectores dominantes es decirnos sobre qué tenemos que hablar. Y después que ellos han definido sobre qué tenemos que hablar, no les importa si el que habla es más progresista o menos progresista, pero el camino central es que el tema de conversación está definido desde el poder. ${ }^{121}$
\end{abstract}

Há em Walsh uma desconfiança quanto às possibilidades de sua escrita captar a realidade do mundo, substrato da sua literatura. Walsh utiliza dois focos narrativos que disputam o espaço gráfico. O autor, simplesmente, toma partido. O protagonista e os acontecimentos em que se vê envolvido

120 WALSH, Rodolfo. "El violento oficio de escritor". In: BASCHETTI, Roberto. Rodolfo Walsh, vivo. Ed. cit., p. 32..

121 PIGLIA, Ricardo. La ficción paranoica. Buenos Aires: Universidad de las Madres de Plaza de Mayo, I Seminario de Análisis Crítico de la realidad argentina 1984-1999, 25 set. 1999 (informação oral). 
não são apresentados senão mediados pelas lembranças da encarregada da pensão ou do seu chefe e pela carta que o próprio deixa e que fica sem abrir, "desqualificada" que é, no bolso de Otero.

A possibilidade de chegar a um relato "verdadeiro" está questionada. Walsh assume a "verdade" contida na carta de León. Ele toma partido, mas não escamoteia a dificuldade. Não é novo em Walsh o recurso à voz de um suicida ou de um "morto"122. Os protagonistas falam como cadáveres, isto é, livres já das relações de poder que escamoteiam a verdade.

León é o outro do escritor, o não letrado que revela ao autor sua condição relativamente privilegiada. Nesse sentido, interpela o intelectual, denuncia-o. Um sentimento ambíguo que às vezes toma forma de culpa e outras de vergonha impregna o texto. A existência de tal personagem instiga o autor a uma reflexão moral sobre o lugar que ele ocupa. Não se trata de uma consciência social independente da atividade literária, mas de um conhecimento resultante de levar a prática da escrita ao limite de suas possibilidades na tentativa de apreender o não letrado. Este conhecimento conduz a uma inquietação de motivação moral em relação à sua prática de escritor e essa inquietação modifica, logo no início, a sua própria escrita. Nela o escritor coloca em dúvida a possibilidade de representar a realidade do seu outro e, por isso, de representar a realidade como um todo. Não pode, caritativamente, "dar voz a quem não tem".

122 Em La granada, um soldado está amarrado a uma bomba que não pode ser desativada e da qual não pode se afastar. Em Operación Masacre, há um "fusilado que 
O personagem León quer sair do universo não letrado e apropriar-se da alta cultura, mas fica na metade do caminho: longe dos trabalhadores manuais, com os quais, porém, partilha o quarto de pensão, e sem nunca conseguir ingressar no universo dos letrados.

Se há alguma coisa que León possui é a sua solidão, incapaz de qualquer comunicação mais profunda com outro ser humano. A única experiência amorosa começa pela iniciativa do outro, na chuva, que permite o encontro. Mas logo fracassa, pois a parceira o abandona. A perda serve apenas para revelar a falha na própria natureza do personagem. Não tendo conhecido os pais, o personagem não viveu a experiência dessa perda original. O encadeamento de perdas como uma maneira de delinear o perfil do sujeito não é possível. León parece ter convivido por muito tempo com o sentimento de uma falta, mesmo que difusa. Essa carência o levou ao suicídio, mesmo ou talvez, porque seus esforços o tinham levado para bem longe de onde começara: "del cotiledón al árbol de Navidad” (p. 89).

Mas se a impossibilidade de viver a perda, de elaborá-la conscientemente, instala- se no indivíduo, ela está associada a um contexto social de separação entre trabalho manual e intelectual, de relações de exploração e de opressão que se fundaram na violência e que permanecem na forma de trauma na medida em que "disso não se fala". León compara os seus patrões com o pai que não teve, mas seria inverossímil que não tivesse alguma consciência da desordem do mundo, mesmo que vista como "la 
generalidad de las cosas" ou deslocada para "Vietnam y los negros del Sur" (p. 78).

De toda maneira, exploração e escamoteio da exploração caminham juntos, ainda que se trate do silêncio sobre o trabalho presente na produção e reprodução social . É Otero, o chefe, quem diz que "la gente que trabaja, [...] es al fin la que hace lo que puede existir de grandeza en el país, en la Casa" (p. 85). Essa verdade escapa ao conhecimento de León, mas não escapa ao leitor, pela tensão instalada por Walsh entre as opiniões de Otero e as informações contidas na carta de León.

Porém, a melancolia de León impregna, contamina tudo que toca. Não há uma alegria suficientemente vigorosa para opor e conter o avanço dessa tristeza densa: Otero quer logo se livrar do morto e passar sobre ele "juicio y sentencia, y uma suave untura de olvido y perdón" (p. 71). Ambos prefeririam, para sua própria tranqüilidade, por uma pedra sobre o assunto. "Por uma pedra" equivale a "fazer um monumento", construir uma lembrança "congelada" no passado, que não interrogue o presente, como aponta Seligmann-Silva em Literatura e trauma: o novo paradigma. Inclusive o presente do leitor. Esse procedimento é rejeitado por Walsh. A sua literatura não é "conciliadora". A tensão permanece no texto até o final, ainda quando se dá espaço ao texto de León e ele toma conta de todo o espaço gráfico da página, continua sendo uma carta na nota de rodapé.

\section{A "série dos irlandeses"}




\section{As relações de poder e o fim do herói individual}

Os contos ambientados no internato para irlandeses pobres se inserem em pelo menos duas tradições da literatura argentina. Por um lado, a dos relatos escolares, série inaugurada por Juvenília, de Miguel Cané, e, por outro lado, a tradição borgeana que procura na história irlandesa uma metáfora das relações de lealdade e traição ${ }^{123}$. Vale a pena, porém, pensar essa inserção a partir das formas que distanciam os contos de Walsh desses modelos. Se em Juvenilia há uma recuperação do passado pela exaltação do período de formação dos jovens da elite portenha do século XIX, com traços picarescos e da literatura de costumes, na série dos irlandeses nos deparamos com um olhar que nada tem de saudosista. A série não trata dos filhos da elite, trata do refugo da imigração, personagens que denunciam o sonho frustrado de inclusão e progresso. Os irlandeses de Walsh não são heróis épicos, nem sequer de uma épica renovada na paródia, no relato escuro de segunda ou terceira mão, que põe em dúvida a veracidade dos acontecimentos narrados. Os irlandeses de Walsh são argentinos pobres. E é como se a pobreza igualasse todas as tradições e despisse qualquer narrativa de elementos heróicos.

Walsh, porém, primeiro desmancha qualquer ilusão de herói épico, torna os personagens "terrestres" demais; para construir, depois, a partir desses seres comuns, uma "épica possível", a partir de pequenos gestos humanos, que apenas ultrapassam a expectativa de submissão. Pequenos

123 Ver, por exemplo, Tema del traidor y del héroe, obra já citada. 
gestos éticos, que talvez tenham sido imaginados por Walsh a partir da leitura da obra de Crocce.

Quando Walsh convoca, nesta série, sua própria memória de interno numa escola para irlandeses pobres, faz valer sua irishness como atributo legitimador da veracidade do relato. Suspeito que o autor também tenha procurado na sua memória sinais que apontassem à construção de uma visão de país que precisava entender e explicar.

A série é composta por três contos: Irlandeses atrás de un gato, Los oficios terrestres y Un oscuro día de justicia. Porém, Walsh disse, em entrevista a Ricardo Piglia, em 1970, que tinha idéias para prolongar a série com mais dois contos. Um deles já tinha nome: Mi tío Willy, que ganó la guerra. O outro teria a intervenção do diabo no seu enredo. Os dois ocorreriam no espaço da enfermaria do internato. Pensava Walsh, naquela época:

Es probable que la historia final la constituyan seis o siete historias que constituyan uma novela hecha por cuentos, todos episódios transcurridos em um año hasta el último día en el colegio. ${ }^{124}$

O conto que inicia a série, Irlandeses atrás de un gato, é o relato da inclusão de um novo interno pelo recurso à violência. O "batizado" do "gato" permite medir sua força e sua esperteza para driblar o castigo num jogo de reconhecimento. A inclusão é a inclusão dentro de uma hierarquia que reproduz, em toda a cadeia de relações, a opressão dos mais fracos pelos 
mais fortes, matriz imposta pela própria instituição, fractalmente presente em todas as instâncias.

O "gato" do primeiro conto aparece no segundo, Los oficios terrestres, completamente integrado. Porém, capaz de gesto de extrema solidariedade, patrocinando a fuga de um interno mais fraco. A metáfora do internato/país tende para a construção de "el pueblo". No começo, com pequenos gestos como o do "gato".

Mas é no terceiro conto, Un oscuro dia de justicia, que a alegoria se completa. Walsh disse na entrevista a Piglia que é este o conto mais político da série:

Por otro lado, hay una cierta evolución en la serie, en este cuento aparece... una nota política, la primera más expresamente política, porque había una connotación política en todos los otros, pero mucho más simbólica e inconsciente. ${ }^{125}$

É uma alusão direta ao Che e uma crítica ao foquismo. Nele se anuncia uma convicção que apareceria nos seus documentos de polêmica com a direção de Montoneros anos depois. Também é o último texto de ficção que Walsh publicou. No enredo, um dos internos, menino franzino, sofre violência sistemática de parte de um zelador, que o obriga a lutar box com o "gato". Decide escrever para o tio Malcolm, com ajuda de "el pueblo", para quem a figura do parente do colega vai crescendo até adquirir a estatura do herói vingador. O tio aparece no internato para castigar o zelador, mas 
termina levando uma surra.

[...] el pueblo aprendió que estaba solo y que debía pelear por sí mismo y que de su propia entraña sacaría los medios, el silencio, la astucia y la fuerza, mientras un último golpe lanzaba al querido tío Malcolm del otro lado de la cerca donde permaneció insensible y un héroe en la mitad del camino. ${ }^{126}$

Na entrevista a Piglia, Walsh explicita que o trecho acima é uma referência a Che:

Creo que ése es el pronunciamiento más político de toda la serie de los cuentos y muy aplicable a situaciones muy concretas nuestras: concretamente al peronismo e inclusive a las expectativas revolucionarias que aquí se despertaban o se despertaron con respecto a los héroes revolucionarios, inclusive con respecto al Che Guevara, que murió en esos días, te das cuenta, la gente que te decía: 'Si el Che Guevara estuviera aquí, entonces yo me meto y todos nos metemos y hacemos la revolución'... Concepto totalmente místico, es decir, el mito, la persona, el héroe haciendo la revolución en vez de ser el conjunto del pueblo, cuya mejor expresión es sin duda el héroe, en este caso el Che Guevara, pero ningún tipo aislado, por grande que sea, puede absolutamente hacer nada. Es decir, cuando se delega en él lo que es una cosa de todos, no se da el proceso, no se puede dar. Creo que ésa es la lección que ellos aprenden ese día; no es un tipo venido de afuera, porque no hay ninguna connotación peyorativa para el tipo que viene de afuera, que pelea, se juega y es un héroe. No deja de ser un héroe por el hecho de que el otro lo cague a patadas, pero lo que ellos aprenden es que ellos, en una segunda instancia, si es que ellos se la quieren cobrar con respecto al celador, se tienen que combinar entre ellos, y cagarlo a patadas entre todos. Ésa es la lección. ${ }^{127}$

O "abandono" da literatura e da autoria por Walsh coincide com essa

convicção que ele adquire e plasma neste conto a propósito do fim do herói

individual.

\section{Imaginaria}

la política". In: BASCHETTI, Roberto. Rodolfo Walsh, vivo. Ed. cit., p. 63.

126 WALSH, Rodolfo. "Un oscuro día de justicia". In: Cuentos. Ed. cit., p. 59.

127 WALSH, Rodolfo. "Hoy es imposible en la Argentina hacer literatura desvinculada de 


\section{Astúcia como inteligência de pobre}

Há neste conto um ensaio de exercício tático. O soldado/narrador utiliza o presente e o futuro. Narra em futuro porque está planejando. 0 registro é de um interiorano pobre que está fazendo o serviço militar. "Imaginaria" é o nome dado, no jargão militar, para o soldado que faz a sentinela à noite e para a própria atividade. Mas é também uma referência à imaginação do soldado que planeja uma vingança, ou, segundo se veja, um pequeno ato de justiça, digamos, compensatória.

Ele tem ordem de dar a voz de alto a quem se aproximar e pedir que se identifique. Se aquele que se apresentar não responder, deve atirar primeiro um disparo de prevenção e depois diretamente ao desconhecido. $\mathrm{O}$ país não está em guerra, não há perigo, mas essa é a ordem. Essa é sua noite de folga, uma noite de sábado, e ele pretendia se encontrar com uma moça, a namorada que conseguiu com muito esforço. Sabe-se feio e pobre; sabe que essa noite ela vai sair com outro, um civil que há tempos a procura e tem uma camionete, porque o soldado ficou de castigo na sua noite de folga. O motivo é um esquecimento do sargento, que se livrou de sua responsabilidade jogando a culpa no soldado. $O$ tenente acreditou no sargento, porque "la verdad viene de mayor a menor, usted le cree a él y no me cree a mi, y el hilo se corta por lo más delgado“"128.

la política". In: BASCHETTI, Roberto. Rodolfo Walsh, vivo. Ed. cit., p. 64.

128 WALSH, Rodolfo. "Imaginaria". In: Los oficios terrestres. 4". Edição. Buenos Aires: de la Flor, 2000 , p. 64 . Neste capítulo, as referências a "Imaginaria" que aparecem a seguir indicam as páginas desta edição. 
O narrador mantém um diálogo imaginário com o tenente. Sabemos

por esse diálogo que o soldado recebe do superior um tratamento

humilhante. Mas o soldado leu o regulamento e conhece as artimanhas do superior. Finge estar dormindo. Como ele tinha previsto, o tenente tira o carregador da sua arma, mas o soldado tem outro preparado para a ocasião.

Espera que o tenente retorne do reconhecimento dos outros imaginárias e, quando retorna, o soldado dá voz de alto e atira para matar. Tem contas a acertar, contas acumuladas. Depois atira para o céu, é o tiro "de prevenção".

A pesquisadora Adriana Imperatore analisa o conto a partir dos conceitos de "tática" e de "estratégia".

Las estrategias postulan un lugar de poder, constituyen sistemas de discursos totalizantes capaces de articular lugares físicos donde las fuerzas son repartidas. Las tácticas juegan en el terreno impuesto, lo cual les confiere movilidad, por eso dependen de la astucia y del sentido de la oportunidad del instante y del azar. Estas tácticas metaforizan el orden dominante y lo hacen funcionar en otro registro, constituyen desvíos sin abolirlo, son procedimientos que logran su diferenciación en el mismo lugar que ocupan. Hay apropiación cuando, en un terreno que no es el propio, un sujeto produce el gesto que le permite inscribir su práctica diferencial. ${ }^{129}$

No fluxo de pensamento, na imaginação realista do soldado, a

129 IMPERATORE, Adriana. "Voces, prácticas y apropiaciones de lo popular en la ficción de Walsh. In: ZUBIETA, Ana M. (comp.): Letrados iletrados. Apropiaciones y representaciones de lo popular en la literatura. Buenos Aires: Eudeba, 1999, p.175. Os conceitos de "tática" e "estratégia" utilizados por Imperatore na sua argumentação são de Michel De Certeau, que os desenvolveu amplamente em $A$ invenção do cotidiano. Para De Certeau, quem tem poder é aquele que traça as estratégias e aos que não o possuem resta apenas desenvolver táticas para, dentro de um campo em que as regras de jogo foram estabelecidas por outros, atingir objetivos parciais que lhes são próprios. O procedimento de usar de uma norma dominante em benefício dos subalternos presente no enredo do conto é uma constante na história argentina desde o "Plan de Operaciones" dos patriotas de 1810. Trata-se, exatamente, de operações de inteligência, as que as classes subalternas podem realizar, como a criação por Walsh, durante o primeiro ano da ditadura, da ANCLA (Agência de Notícias clandestina). O nome, "âncora" em castelhano, confundiu as Forças Armadas: o Exército supunha que se tratava de um empreendimento da Marinha de Guerra e esta suspeitava de uma operação do Exército para promover a divisão dentro da arma. Walsh se aproveitava de uma rixa entre os militares, para evitar uma repressão imediata. 
preparação da ação se dá num diálogo com o tenente. E uma série de pistas vão aparecendo no desenrolar da ação, que nos dão conta da astúcia do soldado, astúcia como inteligência dos pobres. Ele não pode ser "doctor", como sugere o tenente, mas lê o código. Procura nele uma brecha, por mínima que seja, para dela tirar vantagem. Estuda o comportamento do outro.

Como os personagens de Kafka, o soldado de Imaginaria está mergulhado num emaranhado que não parece ter sentido. Mas, ao contrário deles, ele procura a lógica interna do código escrito e da manipulação que deles fazem os chefes, para fugir da disciplina que entende como inútil e perversa. Ironiza um regulamento que o obriga a fazer guarda em tempo de paz.

El fusil ahí se lo dejo, ni siquiera lo toco con la mano, está cargado, con el seguro puesto. Si viniera el enemigo, no hay nada que hacerle, pero qué quiere que le diga mi teniente, los chinos y los rusos están lejos, para mí que ya no vienen esta noche. (p.64)

O "imaginária" do conto tem muito do soldado de La granada, uma das duas peças de teatro de Walsh. Aquele soldado que é inocente, é o portador de uma verdade, justamente, porque está aí obrigado. Preferiria estar em outro lugar, mas está fazendo o serviço militar, assim como soldado Rodríguez, já mencionado, e o soldado que relata a morte da filha, Vicky Walsh, e cujo depoimento é citado na Carta a mis amigos.

Há, na tessitura deste conto, alguns procedimentos líricos que aparecem, reiteradamente, em Esa mujer, como, por exemplo, a associação 
entre o tenente agonizante e a namorada, que torna ambos reduzidos, dominados pelo soldado/narrador:

Y ahora quién va a decir que no le di el alto, como corresponde, y que usted no contestó, y que no disparé un tiro de prevención, como dice el reglamento, y que después no maté a un desconocido sospechoso que se me abalanzaba con una bicicleta. Aunque ese desconocido sea usted mi teniente, y esté boqueando mi teniente sobre el pasto y pegando unos grititos como si fuera una mujer, como si fuera la Julia, y le encuentro el cargador que me sacó y lo tiro a la asequia antes que lleguen los otros imaginarias blancos por la luna y el julepe. (p. 68)

Há comparações e sínteses de imagens que são tiradas da fala popular, como uma lírica ao alcance dos subalternos:

Pero es que no hay novedad mi teniente, el enemigo está a ciento veinte años de distancia, aquí nunca hay novedad y el cielo es lo único que cambia de lugar. (p. 64)

[...] ahora tengo el dedo en el primer descanso como me enseñaron en el polígono, alto mi carajo, un tironcito más y esa escupida colorada que le llega hasta la frente, y mientras usted alza los brazos y empieza a bambolearse en una ese que no va a terminar, y mientras todos los perros del mundo están ladrando, ya he movido el cerrojo y otra escupida colorada, aunque ahora no le apunto a usted sino a las Tres Marías, quién dice que no llega. (p. 68)

É neste conto, e em Esa mujer, que Walsh talvez tenha mais experimentado com a linguagem usando procedimentos líricos que também são capturados das variantes populares, como se o autor se apropriasse de uma riqueza que é reconhecida na dinâmica da linguagem coloquial.

\section{Esa mujer}

Obra literária e peça de inteligência

Durante dez anos a fio, numa pesquisa de opinião realizada por Sergio 
Olguin entre escritores e editores, Esa mujer aparece considerado como o melhor conto da literatura argentina.

O conto é um "duelo" entre um intelectual e um coronel, narrado pelo intelectual. Ele visita o militar, quer negociar uma informação: a localização do cadáver de uma mulher, esa mujer. Em troca, oferece documentos que interessam ao coronel. $\mathrm{O}$ enredo está narrado no presente e o narrador é autodiegético. Seu fluxo de pensamento está intercalado com o diálogo.

O cadáver em questão é o de Eva Perón, nome que não aparece no texto. Dois homens disputam um corpo feminino. Há entre eles o terreno comum da cultura, da arte, das letras, da história. Adivinhamos uma vergonha do intelectual por partilhar alguma coisa com o militar.

O espaço da narrativa é o apartamento onde se realiza o encontro, que, pelas referências ao rio, imaginamos localizado no Barrio Norte, região nobre de Buenos Aires.

No começo, a tensão é sublinhada por uma série de paralelismos:

- Es puntual como los alemanes - dice.

- O como los ingleses.

El coronel tiene apellido alemán. ${ }^{130}$

130 WALSH, Rodolfo. "Esa mujer". In: Los oficios terrestres. 4‥ Edição. Buenos Aires: de la Flor, 2000, p. 9. Neste capítulo, as referências a "Esa mujer" que aparecem a seguir indicam as páginas desta edição. 
O autor não escreve, mas o leitor completa: o escritor tem sobrenome inglês, ou irlandês.

El coronel busca unos nombres, unos papeles que acaso yo tenga. Yo busco una muerta; un lugar en el mapa.[...]

- Esos papeles -dice.

Lo miro.

- Esa mujer, coronel.

Sonríe. (p. 10)

Depois, o narrador quer deixar clara para o leitor sua distância do interlocutor. Parece querer explicar o esforço para ser diplomático, falso com o coronel. Sente pelo militar desprezo intelectual.

Sonrío ante el Jongkind falso, el Figari dudoso. Pienso en la cara que pondría si le dijera quién fabrica los Jongkind, pero en cambio elogio su whisky. (p. 10)

Colocaram uma bomba na porta do apartamento do coronel.

- Mucho daño? -pregunto. Me importa um carajo.

[...] - ¡Como no me va a importar! (p. 10)

Uma série de repetições atravessam o conto para indicar a condição dominante do militar nesse confronto:

Él bebe con vigor, con salud, con alegria, con superioridad, con desprecio. (p. 10)

El coronel bebe con ardor, con orgullo, con fiereza, con elocuencia, con método. (p. 13)

El coronel bebe. Es duro. (p. 13)

El coronel bebe con coraje, con exasperación, con grandes altas ideas que refluyen sobre él como grandes y altas olas contra un peñasco y lo dejan intocado y seco, recortado y negro. (p. 17) 
Esta última imagem remete a uma anterior:

Algum dia (pienso en momentos de ira) ire a buscarla. Ella no significa nada para mí, y sin embargo iré tras el misterio de su muerte, detrás de sus restos que se pudren lentamente en algún remoto cementerio. Si la encuentro, frescas altas olas de cólera, miedo y frustrado amor se alzarán, poderosas, vengativas olas, y por un momento ya no me sentiré solo, ya no me sentiré como una arrastrada, amarga, olvidada sombra. (p. 10)

Podemos supor que as "vengativas olas" se dirigem ao militar e aquilo que ele representa. Mas o coronel permanece "intocado y seco", mesmo perante as suas próprias "altas ideas que refluyen sobre él como grandes y altas olas contra un peñasco".

Quando este conto foi publicado, foi recebido como literatura no sentido estrito. Porém, há suspeitas quanto à veracidade do encontro. Walsh teria ido negociar com o Coronel Moori Koening informações sobre a localização do cadáver de Eva Perón em troca de documentos reunidos por Walsh durante a investigação do caso Satanowsky e que incriminariam militares rivais do coronel.

Em todo caso, em Santa Evita ${ }^{131}$, Tomás Eloy Martinez inclui um encontro em Roma entre Walsh e ele próprio, ambos como personagens literários. Nesse encontro há referências explícitas à negociação de Walsh para descobrir o lugar em que o cadáver de Eva Perón se encontrava. Tomás Eloy Martinez, assim, também tematiza o jogo de espelhos entre a ação

131 MARTínEZ, Tomás Eloy. Santa Evita.Trad. Sérgio Molina. São Paulo: Companhia das Letras, 1996. 
política de Walsh e sua literatura, como ele próprio fizera em Esa Mujer. E talvez seja este o conto em que a tensão entre as duas atividades se manifesta mais claramente. Nele, há um investimento no desejo pessoal de abandonar a solidão da sua condição de intelectual e se diluir "no povo", e na sua articulação com o desejo coletivo de recuperar o corpo de Eva. Contraditoriamente, o protagonismo na recuperação do corpo permitiria ao intelectual um reconhecimento do povo como parte do coletivo. Para um e o outro, o desejo se fixa metaforicamente num corpo feminino.

O fato de o corpo não poder ser nomeado ${ }^{132}$ é indicado pela referência permanente a esa mujer sem que o nome apareça em momento algum. Mas o efeito é também o daquele de brilla por su ausencia. O corpo e o nome estão interditados.

A recepção inicial foi o de um texto de ficção. Só muito tempo depois falou-se no conto como crônica fiel de um encontro entre Walsh e o Coronel. O conto também funcionava como uma justificativa para uma visita que poderia ser julgada como comprometedora. A explicação contida no conto era álibi para Walsh. Sem diminuir a condição e o valor literários do texto, ele era, também, uma peça de inteligência.

\section{Os contos como espaço de experimentação}

Talvez a experimentação de procedimentos nos contos indique a

132 Na época a menção a Eva Perón e Juan Perón era proibida nos meios de comunicação. 
procura de uma eficiência que seria aplicada ao conjunto da obra. Talvez a escolha pela forma do conto, e não do romance, obedeça a razões políticoliterárias. Se o romance, como forma narrativa, pretende dar conta da totalidade da vida e da história, a forma breve do conto está muito mais próxima à circunstância, à oralidade que apenas tenta apreender um fragmento, uma experiência que não se encaixa num grande relato. $O$ conto está perto da confidência entre pares, costuma ser menos assertivo e se presta a um ajuste de sentido sempre renovado a cada vez que uma nova leitura acontece. O narrador do conto, testumunha direta ou indireta da experiência, parece estar prestes a pedir ao leitor que the explique um sentido que the escapa e nessa medida aproxima-se às formas da literatura testemunhal.

A escolha de Walsh não é, em princípio, uma recusa ao grande relato. É, antes, uma adequação da literatura ao tempo histórico que viveu e à sua perspectiva sobre esse tempo. Coincide com a crítica que depois faria à direção da organização Montoneros, que agiu como partido, como representante de um movimento de massas que não a seguia. Sua experiência político-literária desde a escrita de Operación Masacre havia dado ao autor alguns indicadores da eficiência na prática política de ouvir aqueles que não estavam politicamente organizados, de incluir suas vozes e argumentos, de não pretender resolver no papel as tensões ainda não resolvidas nas práticas das grandes massas populares. Os contos dos quais tratei neste capítulo parecem apontar para esses pressupostos. 
As pequenas astucias do soldado de Imaginaria não superam o estágio da ação individual, da pequena revanche. A tensão entre o discurso de León e o de Otero em Nota al pie não se resolve e nem resulta numa aquisição de consciência, num aprendizado do herói. A tentativa do intelectual de romper com a sua solidão pelo recurso restrito da escrita é frustrada se não se resolver na sua ação política, como aparece apontar o desenlace de Esa mujer.

Mas há uma consciência das possibilidades da escrita, da sua eficiência na produção de sentidos, como a alegoria de La máquina del bien y del mal registra. $\mathrm{O}$ vigor da literatura e sua eficiência para "restituir" um sentido negado, para reverter o processo apontado por Benjamin: "[...] se o inimigo vencer, nem mesmo os mortos estarão a salvo dele. E esse inimigo ainda não parou de vencer"133. O recurso às formas testemunhais, intuídas no enredo de Los ojos del traidor, é a busca de "humanização" das vítimas pelos procedimentos de uma operação narrativa, e a transformação de cadáveres, carne destroçada, em heróis, esse herói que é fraco quando sozinho, quando se pretende erigir em representante do coletivo, como na "épica" frustrada de Un oscuro dia de justicia e como no projeto foquista de Guevara.

Essas reflexões que aparecem nos contos de Walsh, tanto nos seus temas como pela experimentação formal, conduziram-no a práticas políticas que procuram a ação coletiva, mas sem eludir a responsabilidade individual. 
A recusa que vai se afirmando nos últimos anos de Walsh é a recusa à substituição da ação coletiva pela individual e à falta de individuação dos atores pelo procedimento da representação ou da delegação do coletivo numa entidade abstrata. Esta convicção aparece nos documentos de polêmica com a direção de Montoneros e nas cartas pessoais, que serão motivo das reflexões do quarto e último capítulo deste trabalho. 


\section{Capítulo 4: As cartas pessoais ${ }^{134}$}

Na madrugada de 10 de junho de 1956, o general Juan José Valle é condenado à morte por fuzilamento por um tribunal marcial. Ele se levantou contra o governo da "Revolución Libertadora", aquela que Walsh chamará de "fusiladora", alcunha que se propagará à boca pequena até alcançar todo o território nacional.

O crime pelo qual Valle é condenado é o de ter organizado um putch cívico-militar, junto com o general Tanco, que consegue asilo e, assim, salva a vida. Valle e Tanco estão entre os poucos oficiais de alta patente do Exército que permaneceram leais a Juan Domingo Perón, presidente constitucional derrubado pelo golpe de Estado e exilado pouco menos de um ano antes .

O putch estava fadado ao fracasso. Sem força entre os militares e com apoio civil pequeno, num contexto de desorganização dos sindicatos, com as sedes sob intervenção e com os velhos dirigentes educados não na luta, mas na participação nos organismos do Estado, que, separados dos aparatos, são incapazes de agir.

134 Da série de cartas pessoais que Rodolfo Walsh escreveu nos últimos meses da sua vida, vou me deter em Carta a Vicky, Carta a mis amigos e Carta abierta a la junta militar. Particularmente a terceira costuma ser considerada como "o legado" de Walsh para as gerações futuras de argentinos. Talvez isto se deva à vigência da avaliação que traçou para o país, mas também por ser um ponto de inflexão no posicionamento do intelectual a propósito da história e do conjunto da sociedade, expresso numa forma textual. É assim que ela vêm sendo lida em todos estes anos, já se constituindo, inclusive, junto com Operación Masacre, leitura obrigatória nos cursos de segundo grau. Mas, antes de tratar esse fato, vou refletir sobre o lugar que essas cartas ocupam na obra do autor, as condições de produção e suas possíveis fontes de inspiração. Para isso, creio necessário retroceder um par de décadas, para outro momento de inflexão, também, na vida de Walsh. 
As informações sobre o putch vazaram. E os assaltos aos quartéis sucumbiram às emboscadas para eles preparadas. O governo podia, inclusive, ter evitado os confrontos. Mas achou que era uma oportunidade, uma desculpa, para infringir um castigo exemplar, na realidade, de caráter preventivo ante possíveis novos levantamentos.

Valle é impedido de se despedir pessoalmente da família e escreve, nessa madrugada, cinco cartas: uma à filha, uma à esposa, uma à sua mãe, uma à irmã e uma outra ao general Pedro Eugênio Aramburu, presidente de fato e padrinho do seu casamento. Valle, na primeira tentativa de golpe contra o governo constitucional, aconselhou Perón, na frente dos oficiais então legalistas, depois participantes do golpe triunfante, a armar a $\mathrm{CGT}^{135}$. Como é sabido, Perón não armou a CGT, foi derrubado pelos seus ex camaradas de armas e se exilou. Mas os militares nunca perdoariam Valle por aquele conselho. Esperavam o momento para acertar contas com ele.

As cartas chegam às mãos da família Valle, que as faz circular. Em forma de panfletos, são reproduzidas e vão alimentar uma discussão sobre a legitimidade do governo e também sobre a legitimidade do levantamento de Valle e Tanco, que, não sem razão, tem sido caracterizado no seu momento como aventureiro.

As cartas de Valle causam grande impressão. O fato de ele tê-las

135 Confederación General del Trabajo (central sindical). 
escrito instantes antes de morrer confere a elas um "peso de verdade". Para que mentir nessa hora? Todo o tom delas é moral e sua leitura vai ao encontro de uma necessidade da recuperação de uma auto-estima machucada pelo discurso do governo e dos meios de comunicação sob censura ou mesmo cúmplices.

Seu conteúdo, em particular o da carta dirigida a Aramburu, é reforçado pelas investigações de Walsh sobre os fuzilamentos ilegais de 9 de junho, que serão publicadas na forma do livro Operación Masacre em fevereiro de 1957.

Walsh, assim como os seus contemporâneos, leu as cartas de Valle nesse período que vai de junho de 1956 a fevereiro de 1957, momento em que ele sentia suas certezas políticas abaladas. Ele havia apoiado o golpe contra Perón em nome, também, de valores morais, como indicam os artigos 2-0-12 no vuelve ${ }^{136}$ e Aqui cerraron sus ojos ${ }^{137}$, publicados originalmente na revista Leoplán, em 21/12/1955 e 1/10/1956 respectivamente. Durante a escrita de Operación Masacre experimentou os efeitos de leitura das cartas de grande repercussão na época.

O efeito de recepção era uma questão que, segundo a viúva de Walsh, Lilia Ferreyra, interessava-o desde os oito, nove anos, quando, internado

136 WALSH, Rodolfo. "2-0-12 no vuelve". In: LINK, Daniel (org.). Rodolfo Walsh. El violento oficio de escribir. Obra periodística 1953-1977. 2ª . Edição. Buenos Aires: Planeta, 1998, p. 10-14.

137 WALSH, Rodolfo. "Aquí cerraron sus ojos". In: LINK, Daniel (org.). Rodolfo Walsh. El violento oficio de escribir. Obra periodística 1953-1977. 2ª . Edição. Buenos Aires: Planeta, 1998, p. 15-18. 
numa escola para irlandeses pobres e passando uma semana na enfermaria, contava Os miseráveis, que sua mãe tinha lido para ele e para os seus irmãos, para os outros internos. Segundo Lilia Ferreyra ${ }^{138}$, o interesse com que seus colegas esperavam o novo capítulo tinha causado nele grande impressão.

Talvez essas cartas de Valle tenham inspirado Walsh na elaboração da sua série de cartas pessoais. Especificamente, da sua Carta a Vicky, da Carta a mis amigos e da Carta a la Junta Militar, quando, como Valle, sentiuse na necessidade de falar em seu próprio nome. Valle o fez porque tinha sido traído e ia morrer; Walsh, porque tomava distância da direção da organização da qual fazia parte. Ele teve a oportunidade de observar o efeito das cartas de Valle e podia, então, prefigurar o efeito que teriam as suas.

Valle, além de pedir a seus familiares que cuidassem uns dos outros, pede a eles inteireza para enfrentar as calúnias e reivindica sua luta e seus motivos. Sabemos que as cartas tiveram sobre sua filha Susana, então com dezoito anos, efeito poderoso. Ela tornou-se militante da Juventude Peronista e enfrentou com rara integridade a prisão e a tortura. Estando grávida de gêmeos e a ponto de parir, foi algemada a uma cama de mármore, na morgue de um hospital, e recebeu choque elétrico, provocando o parto prematuro. Como conseqüência das condições em que o parto aconteceu, um dos filhos nasceu morto. O cadáver do bebê foi colocado sobre seu peito. O outro, ainda vivo, foi colocado ao alcance da sua vista, sobre uma mesa de BASCHETTI, Roberto (org.). Rodolfo Walsh, vivo. Buenos Aires: de la Flor, 1994, p.195-201. 
mármore, até que morreu de hipotermia. Sobrevivente a tais tratos, continuou militando e só relatou o acontecido para os mais próximos.

\section{Carta a Vicky. Carta a mis amigos}

Se Valle reivindicava sua própria luta e seus próprios motivos perante sua filha, Walsh, por sua vez, na sua Carta a Vicky e na sua Carta a mis amigos, faz uma reivindicação da luta e dos motivos de sua filha, Victoria Walsh. Na primeira, ele expõe seus sentimentos ao ser informado, pelo rádio, da morte de sua filha, também militante montonera. O assunto é a própria dor, que não pode ser contada senão recorrendo à voz de um desconhecido passageiro de trem suburbano, ouvida de relance. A dor, então, pode ser formulada e compartilhada. A segunda, é o relato da morte de Vicky reconstruído por Walsh a partir do testemunho de um soldado que participou do cerco à casa onde ela se encontrava. Na terceira carta, a Carta abierta a la junta militar, faz uma análise minuciosa da destruição do país operada pela Junta Militar, um ano depois do golpe. A assinatura indica o compromisso pessoal e o texto convoca o leitor a divulgar a carta. Assim retoma a proposta da sua polêmica com a direção de Montoneros, ao retornar à relação corpoa-corpo, olho-no-olho, que tinha sido substituída pela hierarquia e pela concepção militarista que reduz a ação política a um automatismo. Walsh a propõe como um ato de liberdade, não de um herói, mas de um homem ou de uma mulher que se atrevem a contradizer aquilo que lhes é imposto. As matérias da Cadena Informativa, um empreendimento que ele impulsionou, fazendo parte do setor de comunicações de Montoneros, terminam com o 
convite a divulgar a informação:

Reproduzca esta información, hágala circular por los medios a su alcance: a mano, a máquina, a mimeógrafo. Mande copias a sus amigos: nueve de cada diez las estarán esperando. Millones quieren ser informados. El terror se basa en la incomunicación. Rompa el aislamiento. Vuelva a sentir la satisfacción de un acto de libertad. ${ }^{139}$

A Carta a mis amigos é arrematada com a frase: "Esto es lo que quería decirles a mis amigos y lo que desearía que ellos transmitieran a otros por los medios que su bondad les dicte"140. Assim, a assinatura supõe uma decisão pessoal, carregada de subjetividade, que se aproxima a outras decisões pessoais e a outras subjetividades. Vozes que ele recolhe do quotidiano, do indivíduo que se achega a apresentar um testemunho. $O$ texto interpela o leitor.

Talvez conhecendo o peso do exemplo do general Valle sobre as escolhas da filha, Susana, sentiu-se responsável pela opção militante de Vicky. Na Carta a mis amigos toma distância da entrada de sua filha na organização Montoneros, na que ele mesmo já militava:

La forma en que ingresó en Montoneros no la conozco en detalle. A la edad de veintidós años, edad de su probable ingreso, se distinguía por decisiones firmes y claras. Por esa época comenzó a trabajar en el diario La Opinión [onde Walsh também tinha trabalhado] y en un tiempo muy breve se convirtió en periodista. El periodismo no le interesaba. Sus compañeros la eligieron delegada sindical. ${ }^{141}$

139 WALSH, Rodolfo. Apud: VERBITSKY, Horacio. Rodolfo Walsh y La prensa clandestina. 1976-1978. Buenos Aires: Urraca, 1985, p. 11.

140 WALSH, Rodolfo. "Carta a mis amigos". In: BASCHETTI, Roberto (org.). Rodolfo Walsh, vivo. Buenos Aires: de la Flor, 1994, p. 191.

141 WALSH, Rodolfo. "Carta a mis amigos". In: BASCHETTI, Roberto (org.). Rodolfo 
Sobre esta questão, diz María Moreno:

Cuando Walsh escribió Operación Masacre, Vicki debía tener unos pocos años. En tiempos en que los dos Walsh militaban en Montoneros los psicoanalistas decían con simpleza que muchos jóvenes abrazaban la lucha armada en una ecuación edípica mal resuelta con sus padres militares o como un pasaje al acto realizado en nombre de padres que transmitían ideales políticos revolucionarios pero que habían eludido la acción. Ignoraban, amén de la Historia que no cabe en el apretado triángulo del Complejo de Edipo, el hecho de que muchas familias habían puesto el cuerpo al mismo tiempo en la misma causa, aunque a menudo en diversos sectores de la lucha que poco a poco fue haciéndose "armada".

[...] Como padre, Walsh separa a Vicki de su propio legado al afirmar que ignora la fecha exacta en que ingresó a Montoneros y que el periodismo no le interesa. ${ }^{142}$

Os detalhes do relato da morte de Vicky são recolhidos do depoimento de um soldado que participou do cerco. Ele é portador da verdade, como os outros "soldaditos" de Walsh, porque estava aí obrigado. O sentido de alguns dos detalhes escapa ao soldado, mas não ao pai. Eles são, também pelo fato de serem incompreensíveis para o mensageiro, provas da veracidade da descrição:

El 28 de septiembre, cuando entró en la casa de la calle Corro, cumplía 26 años. Llevaba en sus brazos a su hija porque en último momento no encontró con quién dejarla. Se acostó con ella, en camisón. Usaba unos absurdos camisones largos que siempre le quedaban grandes.

[...] "El combate duro más de una hora y media. Un hombre y una muchacha tiraban desde arriba, nos llamó la atención porque cada vez que tiraban una ráfaga y nosotros nos zambullíamos, ella se reía."

He tratado de entender esa risa. La metralleta era una Halcón y mi hija nunca había tirado con ella, aunque conociera su manejo por las clases de instrucción. Las cosas nuevas, sorprendentes, siempre la hicieron reír. Sin duda era nuevo y sorprendente para ella que ante una simple pulsación del dedo brotara una ráfaga y

Walsh, vivo. Ed. cit., p. 188.

142 MORENO, Maria. Sobre la "Carta a Vicky". Buenos Aires: mime, [s/d]. 
que ante esa ráfaga 150 hombres se zambulleran sobre los adoquines, empezando por el coronel Roualdes, jefe del operativo. $^{143}$

Sobre a interpretação de Walsh a propósito do riso de Vicky e da camisola grande demais, comenta Maria Moreno:

Como político, convierte el gesto de reír al disparar un arma en la irresponsabilidad de la inocencia quitándole su posible sentido demencial [...].

Reminiscencias de David y Goliath, también en la descripción del camisón como "demasiado grande" que da un toque personal a la necrológica, humaniza al sujeto integrante de un colectivo a través de un rasgo individual $y$, al darle una dimensión cotidiana, desmilitariza a la protagonista de un gesto que, de otro modo, podría leerse como excesivo y desesperado. Es con la mención de ese camisón demasiado grande que Walsh cubre a Vicki y la virginiza enparentándola con "Esa Mujer", la de su no ficción.

Nesta carta, Beatriz Sarlo, em Uma alucinación dispersa em agonia destacaria seu tom heróico, wagneriano, operístico, espectacular, excesivo ${ }^{145}$. Esse tom, mas também alguma coisa mais profunda do que o tom, está presente num poema de Juan Gelman que a autora nos apresenta como exemplo. Trata-se de uma homenagem ao poeta militante Francisco Paco Urondo:

[...] y después te mataron. Te ibas volviendo más hondo para entonces, más alegre y más humano [...] Paco Urondo murió por la felicidad de los millones que, no aspirando a escribir o prestigiarse, quieren vivir humanamente.

143 WALSH, Rodolfo. "Carta a mis amigos". In: BASCHETTI, Roberto (org.). Rodolfo Walsh, vivo. Ed. cit., 1994, p. 190.

144 MORENO, Maria. Sobre la "Carta a Vicky". Ed. cit.

145 SARLO, Beatriz. "Una alucinación dispersa en agonía". Punto de Vista nº 21. Agosto 1984, p. 2.

146 GELMAN, Juan. Apud. SARLO, Beatriz. "Una alucinación dispersa en agonía". Punto de Vista $\mathrm{n}^{\circ} 21$. Ed. cit., p.3. 
Porém, quando cita a Carta a mis amigos de Walsh, Sarlo não se detém num trecho semelhante ao poema de Gelman sobre Urondo:

Vicky pudo elegir otros caminos, que eran distintos sin ser deshonrosos, pero el que eligió era el más justo, el más generoso, el más razonado. Su lúcida muerte es una síntesis de su corta, hermosa vida. No vivió para ella, vivió para otros, y esos son millones. ${ }^{147}$

O incômodo que o tom produz a posteriori em autores como Sarlo tem a ver, provavelmente, com o efeito de deslocamento ao se reconhecer, anos atrás, no mesmo tom heróico. Isso impede, creio, a Sarlo ver na Carta a Vicky e na Carta a mis amigos, o gesto subjetivo de Walsh que, depois de muitos anos -desde 1969- de diluição da autoria, assume o seu texto de maneira completa. Marca-o com seu nome e sobrenome.

O texto se diferencia de outros textos de militantes de 1977, justamente pelo seu tom subjetivo e por apresentar Vicky com imagens mais perto do retrato familiar do que do "bronze" dos heróis: com a filha nos braços e uma camisola larga demais.

Apesar do suposto tom de heróico notado por Sarlo, há na referência a Vicky um toque próprio de Walsh, da sua visão da ação política, que seria depois formulada de maneira explícita nos documentos de crítica à direção de Montoneros. Essa visão é bem distante do modelo romanesco. O autor apresenta a ação política como uma sucessão de pequenos gestos de resistência. Isso não é novo no autor: por exemplo, quando tenta publicar as 
reportagens que depois conformarão Operación Masacre sem conseguir editor de jornal que aceite a informação, como relata no prólogo:

[...] encuentro un hombre que se anima. Temblando y sudando porque él tampoco es un héroe de película, sino simplemente un hombre que se anima y eso es más que un héroe de película. ${ }^{148}$

Essa mesma visão está presente na escolha de La cólera de un particular para El libro de los autores ${ }^{149}$. Tratava-se de uma coletânea na que vários escritores argentinos eram convidados a indicar o conto preferido. Havia nas escolhas uma certa constante. Ernesto Sábato escolheu Bartleby, de Herman Melville. Jorge Luis Borges indicou Wakefield, de Nathaniel Hawthorne. Nenhum dos três escolhem um herói épico. Mas, enquanto Sábato e Borges apostam na recusa passiva, Walsh põe as suas fichas no indivíduo que "se anima", para ter "la satisfacción moral de un acto de libertad“.

As personagens de Walsh não são os tipos lukacsianos, são seres singulares, "fugas das determinações", como diria Horacio González.

Nas cartas, ele também se coloca como personagem singular, passando da diluição na autoria coletiva, na atribuição dos seus textos à organização, à superexposição do seu nome e identidade, gesto sublinhado na Carta abierta a la junta militar pelo registro do número de seu documento. A forma em que inclui o outro não é a diluição no coletivo. Na Carta a Vicky

Walsh, vivo. Ed. cit., 1994, p. 191.

148 WALSH, Rodolfo. Operación masacre. Ed. cit., p. 20.

149 Anônimo. "La cólera de un particular". In: AA.VV. El libro de los autores. Trad. 
registra, nas últimas três linhas: "Hoy en el tren un hombre decía: 'Sufro mucho. Quisiera acostarme a dormir y despertarme dentro de un año'. Hablaba por él pero también por mí” ${ }^{150}$.

O homem do trem dá a Walsh as palavras para falar de sua dor. Alguém pode explicar o gesto pela dificuldade de encontrar um jeito de narrar, quando a violência o atingiu no seu âmago, machucando justamente sua capacidade de narrar, um efeito do trauma sobre a linguagem, como descreve Márcio Seligmann-Silva ${ }^{151}$. A voz solidária do desconhecido do trem doaria as palavras necessárias para o luto. O passageiro faz as vezes de espelho de Atena, para poder enfrentar Gorgon. Mas, ainda aceitando essa interpretação, vale afirmar que há em Walsh um pudor. No penúltimo parágrafo da Carta a Vicky diz: "Anoche tuve una pesadilla torrencial, en la que había una columna de fuego, poderosa pero contenida en sus límites, que brotaba de alguna profundidad"152.

A alegoria bíblica permite-lhe descrever o que sente. Talvez um pudor masculino que lhe impede se desmanchar em prantos. A dor está contida, ainda que profunda. E imediatamente é convocada a voz do anônimo, que está no mesmo trem: "Sufro mucho. Quisiera acostarme a dormir y despertarme dentro de un año"153.

Rodolfo Walsh. Buenos Aires: de la Flor, 1967.

150 WALSH, Rodolfo. "Carta a Vicky". In: BASCHETTI, Roberto (org.). Rodolfo Walsh, vivo. Ed. cit., p. 187.

151 SELIGMANN-SILVA, Márcio. "A história como trauma" in: NETROVSKI, Arthur e 2000, p. 73-98. (orgs.). Catástrofe e Representação. São Paulo: Escuta,

152 WALSH, Rodolfo. "Carta a Vicky". In: BASCHETTI, Roberto (org.). Rodolfo Walsh, vivo. Ed. cit., p. 187.

153 WALSH, Rodolfo. "Carta a Vicky". In: BASCHETTI, Roberto (org.). Rodolfo Walsh, 
Esse gesto de convocar a voz do outro para falar de si será apontado por Piglia, em La ficción paranóica ${ }^{154}$, como um gesto literário e político ao mesmo tempo, ou, como se falaria da ação das Madres de Plaza de Mayo, um gesto que politiza a dor pessoal. Como forma literária reiteradamente freqüentada pelo autor na sua obra investigativa, Piglia aponta que esse seria um procedimento adequado para enfrentar as dificuldades na hora de pretender "escrever a verdade", parafraseando Brecht ${ }^{155}$.

Walsh escreveu a Carta a Vicky no mesmo dia em que soube da morte da filha, pelo comunicado do rádio. Parece ter querido guardar cada detalhe: ouviu o nome dela mal pronunciado, começou a fazer o sinal da cruz maquinalmente, como fazia na infância, mas não terminou. "El mundo estuvo parado en ese segundo"156, registra. E já não é o mediador entre o sobrevivente e o leitor, como em Operación Masacre; ele é o próprio sobrevivente. Há, inclusive, uma declaração de amor: "Me quisiste, te quise [...] El verdadero cementerio es la memoria. Ahí te guardo, te acuno, te celebro y quizás te envidio, querida mía"157. Resiste a se despedir: "Me gustaría verte sonreír una vez más”158.

vivo. Ed. cit., p. 187.

154 PIGLIA, Ricardo. La ficción paranoica. Buenos Aires: Universidad de las Madres de Plaza de Mayo, I Seminario de Análisis Crítico de la realidad argentina 1984-1999, 25 set. 1999 (informação verbal).

155 BRECHT, Berthold. "Cinco maneiras de dizer a verdade". Trad. Florian Geyer. Revista Margem Esquerda 응, novembro de 2006, p. 193-206.

156 WALSH, Rodolfo. "Carta a Vicky". In: BASCHETTI, Roberto (org.). Rodolfo Walsh, vivo. Ed. cit., p. 186.

157 WALSH, Rodolfo. "Carta a Vicky". In: BASCHETTI, Roberto (org.). Rodolfo Walsh, vivo. Ed. cit., p. 186-187.

158 WALSH, Rodolfo. "Carta a Vicky". In: BASCHETTI, Roberto (org.). Rodolfo Walsh, 
O texto tem muito de relato traumático, fantasiado de minúcia jornalística, descrição literal, sem seleção nem hierarquização da informação e os detalhes, como o da camisola ou o riso aparentemente extemporâneo, funcionam como um indício, mas Walsh não escamoteia detalhes. Talvez suspeite que qualquer um deles possa esconder um sentido que lhe escapa e espera, também imagino, encontrar um leitor solidário que retire desses detalhes um significado fugidio.

\section{Carta abierta a la junta militar}

Se a Carta a Vicky e a Carta a mis amigos mantêm um tom subjetivo, a Carta abierta a la junta militar é uma análise sistemática do primeiro ano da ditadura militar instaurada em 76, carregada de dados. A descrição, que aborda a denúncia da repressão, reunindo informações antes de outros e em plena clandestinidade, faz uma radiografia do projeto econômico e político em andamento que ainda não fôra contestado pelos balanços do período completo. Talvez sua atividade de inteligência desse a Walsh acesso a informações confidenciais manejadas nas esferas do governo $\mathrm{e}$ isso permitisse traçar um panorama que antecipava os rumos que seriam seguidos pelo governo militar e pelas administrações civis que se seguiram, em matéria de desnacionalização da economia.

vivo. Ed. cit., p. 186. 
É preciso levar em conta que a avaliação presente na Carta abierta a la junta militar não era compartilhada pela organização à que Walsh pertencia. O distanciamento do autor da direção de Montoneros está presente nessa carta para o público externo à organização ${ }^{159}$. Pela primeira vez e depois de muitos anos, Walsh faz públicas posições políticas que o afastam da direção e o faz assinando com nome, sobrenome e número de documento.

Esta carta, junto com os documentos de polêmica com Montoneros, foram lidos posteriormente como um legado político a ser discutido. Consta nesta carta o reconhecimento dos trabalhadores, e não dos guerrilheiros, como os principais prejudicados, as vítimas preferenciais das políticas da ditadura que se iniciou em 1976. Sua leitura, assim como a de toda a série de cartas pessoais, fica contaminada com a proximidade entre sua produção e a morte do autor, ainda mais esta última carta, já que foi escrita na noite anterior à emboscada que acabou com a vida do escritor. É verdade que a série começa com a morte de sua filha mais velha. Talvez as condições desta morte e a avaliação que o pai faz da opção por não se entregar com vida, somada à morte de Paco Urondo, motivo de outra carta pessoal, Diciembre 29, que, quando se viu cercado, ingeriu a cápsula de cianureto, possam levar a pensar que Walsh se preparava, também ele, para morrer numa situação semelhante. A pistola calibre 22 que carregava a toda parte é também um indício. Walsh tinha plena consciência da inferioridade do poder de fogo dos Montoneros. A pistola calibre 22 era apenas a garantia de não se entregar de 27/8/1976 a 5/1/1977: WALSH, Rodolfo. "Los documentos". In: BASCHETTI, Roberto. 
com vida.

Esse estado de espírito, que provavelmente predominava nos últimos meses da sua vida, não pode ser confundido com depressão, paralisia ou mesmo inércia com relação às orientações gerais da direção montonera. Ao contrário, foi esse seu período mais ativo na crítica ao militarismo e ao foquismo da organização. Há, nesses últimos meses da vida de Walsh, um reverdecer da subjetividade, a assunção da autoria e o distanciamento crítico da direção.

Esse gesto o leva, também, a retomar velhos planos de escrita ficcional. Estava voltando a trabalhar na novela geológica, por camadas. $\mathrm{Na}$ noite anterior a seu desaparecimento não apenas escreveu a Carta abierta a la junta militar. Também escreveu um conto, Juan se iba por el río, do qual sabemos apenas o enredo, relatado por dois dos seus leitores, Lilia Ferreyra e Martín Grass ${ }^{160}$. O conto apresenta um acontecimento que aproxima o relato ao realismo maravilhoso, registro incomum no autor, apenas freqüentado numa das suas peças de teatro, La granada ${ }^{161}$.

No enredo, uma maré baixa deixa o leito do Río de la Plata à mostra e o protagonista pode satisfazer um velho desejo, o de cruzar o Río de la Plata a cavalo. O conto termina no momento em que Juan está no meio do

Rodolfo Walsh, vivo. Buenos Aires: de la Flor, 1994, p. 206-240.

160 FERREYRA, Lilia. "Dos lectores". In: Página/12, Buenos Aires, 9/jan./2006, contracapa. Disponível em: < http://www.pagina12.com.ar/diario/contratapa/13-61457-200601-09.html>. Acesso em: 28 out. 2008 às 18:08.

161 WALSH, Rodolfo. "La granada". In: La granada/La batalla. Buenos Aires: de la Flor, 1988 , p. 5-63. 
percurso e a maré retorna, o que nos faz supor que não chegará ao seu destino. Talvez seja o enredo uma alegoria da aposta daquela geração num projeto emancipatório que o autor antevia frustrado, o que coincide com o que ficou nos seus textos de polêmica com a direção de sua organização e na avaliação apresentada na Carta abierta a la junta militar.

A água e os cavalos estão associados, para Walsh. Segundo Lilia Ferreyra $^{162}$, um cavalo matou seu pai e outro, chamado "Mar Negro", o escritor cavalgou para levá-lo ao campo de uns parentes, atravessando toda uma região de banhados da província de Buenos Aires, rumo ao Sul. Essa cavalgada, Lilia Ferreyra registra, tem a ver com o desejo de retorno às origens, seria uma espécie de fuga ao contrário e que se relaciona com a escolha de permanecer na Argentina, sendo tão conhecido, disfarçado de aposentado num subúrbio semi-rural ao Sul da capital.

Essa opção parece também realizar o pesadelo do protagonista de El Sur ${ }^{163}$, o conto de Borges. Nele, um descendente de britânicos e "criollos", prefere uma morte "bárbara", mas heróica, à de um leito de hospital.

A Carta abierta a la junta militar, porém, não foi escrita como a última carta, como a carta de alguém que vai morrer imediatamente. Não tem a urgência da carta do general Juan José Valle a Pedro Eugenio Aramburu,

162 FERREYRA, Lilia. "Dos lectores". In: Página/12, Buenos Aires, 9/jan./2006, contracapa. Disponível em: < http://www.pagina12.com.ar/diario/contratapa/13-61457-200601-09.html>. Acesso em: 28 out. 2008 às 18:08.

163 BORGES, Jorge Luis. "El Sur”. In: Ficciones. Madri: Alianza, 1998, p. 205-216. 
ainda que tenha o mesmo tom de denúncia e acusação. Difere das outras da série por sua precisão analítica e pela enumeração de fatos. Não perde, porém, o caráter pessoal:

La censura de prensa, la persecución a intelectuales, el allanamiento de mi casa, el asesinato de amigos queridos y la pérdida de una hija que murió combatiéndolos, son algunos de los hechos que me obligan a esa forma de expresión clandestina después de haber opinado libremente como escritor y periodista durante casi treinta años. ${ }^{164}$

Com esse parágrafo, começa a carta. Essa lista inicial inclui as desgraças pessoais como justificativa para o recurso utilizado.

É preciso considerar que se trata de uma carta aberta. $\mathrm{O}$ gênero das cartas abertas supõe um destinatário explícito, mas que não é necessariamente aquele que se quer persuadir, e outro implícito, a platéia que assiste a uma contenda verbal. No caso específico desta última carta de Walsh, não há dúvida. O autor não tem qualquer ilusão de persuadir o assim chamado destinatário.

Horacio González ${ }^{165}$, comparando os repressores de 1956 com os de vinte anos depois, chama a atenção para a impossibilidade de diálogo. Faltaria aos militares da última ditadura um resto de bem, ou um "terreno comum" sobre o qual discutir, persuadir, convencer.

164 WALSH, Rodolfo. "Carta abierta a la junta militar". In: BASCHETTI, Roberto. Rodolfo Walsh, vivo. Buenos Aires: de la Flor, 1994, p. 241. Neste capítulo, as referências a "Carta abierta a la junta militar" que aparecem a seguir indicam as páginas desta edição.

165 GONZÁLEZ, Horacio. Reflexiones en torno al entrecruzamento de la sociología con la investigación periodística y la estructura de la narrativa policial. Buenos Aires: mime, s/d. 
Nos seus contos, Walsh experimentou com o gênero epistolar, pelo recurso de apropriação e captura da voz de um correspondente não letrado em Cartas. No conto, um camponês empobrecido pelas dívidas, depois acusado injustamente de roubo, escreve na penitenciária para a sua filha.

As cartas são também o lugar possível para a voz do sujeito subalterno. Podendo Walsh, escritor consagrado ou quadro militante, inscrever seu texto num "lugar" nobre, da literatura ou do manifesto, escolhe a carta. Essa escolha formal é também uma opção política. Desce ao chão dos comuns e essa opção registra com a ação da escrita o que também propõe em sua polêmica com a direção montonera: descentralização das iniciativas, procedimentos ao alcance da mão de pequenos grupos ou ainda de indivíduos.

Na textura da Carta abierta a la junta militar, ainda sem abandonar um estilo seco e analítico, há jogos de oposição, gradações crescentes e figuras espaciais que doam à sua leitura certa musicalidade a serviço de uma caracterização mais precisa:

[...] lo que ustedes llaman aciertos son errores, los que reconocen como errores son crímenes y lo que omiten son calamidades.

El 24 de marzo de 1976 derrocaron ustedes a un gobierno del que formaban parte, a cuyo desprestigio contribuyeron como ejecutores de su política represiva, y cuyo término estaba señalado por elecciones convocadas para nueve meses más tarde. En esa perspectiva lo que ustedes liquidaron no fue el mandato transitorio de Isabel Martínez sino la posibilidad de un proceso democrático donde el pueblo remediara males que ustedes continuaron y agravaron.

llegítimo en su origen, el gobierno que ustedes ejercen pudo legitimarse en los hechos recuperando el programa en que coincidieron en las elecciones de 1973 el ochenta por ciento de los 
argentinos y que sigue en pie como expresión objetiva de la voluntad del pueblo, único significado posible de ese "ser nacional" que ustedes invocan tan a menudo.

Invirtiendo ese camino han restaurado ustedes la corriente de ideas e intereses de minorías derrotadas que traban el desarrollo de las fuerzas productivtas, explotan al pueblo y disgregan la Nación. Una política semejante sólo puede imponerse transitoriamente prohibiendo los partidos, interviniendo los sindicatos, amordazando la prensa e implantando el terror más profundo que ha conocido la sociedad argentina. (p. 241-242)

O segundo item está regado de números da repressão e nele consta a descrição do seu modus operandi. Começa com uma escala decrescente em quantidade e crescente em certeza: "Quince mil desaparecidos, diez mil presos, cuatro mil muertos, decenas de miles de desterrados son la cifra desnuda de ese terror" (p. 242). E logo passa a descrever os procedimientos da repressão: "Colmadas las cárceles ordinarias crearon ustedes en las principales guarniciones del país virtuales Campos de Concentración donde no entra ningún juez, abogado, periodista, observador internacional” (p. 242). E, sobre a tortura, considerando que foram rejeitados mais de sete mil recursos de habeas corpus, pondera as diferenças com períodos anteriores:

\footnotetext{
De este modo han despojado ustedes a la tortura de su límite de tiempo, como el detenido no existe, no hay posibilidad de presentarlo al juez en 10 días como manda una ley que fue respetada aun en las cumbres represivas de las anteriores dictaduras.

La falta de límite en el tiempo ha sido completada con la falta de límite en los métodos, retrocediendo a épocas en que se operó directamente sobre las articulaciones y las vísceras de las víctimas, ahora con auxiliares quirúrgicos y farmacológicos de que no dispusieron los antiguos verdugos. El potro, el torno, el despellejamiento, la sierra de los inquisidores medievales reaparecen en los testimonios junto con la picana, el "submarino", el soporte de las actualizaciones contemporáneas. (p. 243)
}

Walsh pontua o pronome "ustedes" em quase todos os parágrafos deste item., ao mesmo tempo em que evita a adjetivação. 
No terceiro item há o esforço de desmontar as versões do Estado sobre a repressão, lançando mão de recursos já testados nos seus textos estritamente literários, como a construção adjetivo-sustantivo: “[...] fraguados 'combates' e imaginárias ‘tentativas de fuga' [...]” (p. 244).

Há, também, o recurso irônico à afirmação absurda, já utilizada em "Imaginária", por exemplo: "Extremistas que panfletean el campo, pintan acequias o se amontonan de a diez en vehículos que se incendian [...]" (p. 244).

Já no quarto item, há uma série de relatos de horror recolhidos na atividade de inteligência à qual se dedicava e que tinha como base uma rede informativa alternativa:

Entre 1500 y 3000 personas más han sido masacradas en secreto después que ustedes prohibieron informar sobre hallazgos de cadáveres [...] (p. 246).

25 cuerpos mutilados afloraron entre marzo y octubre de 1976 en las costas uruguayas [...] (p. 247).

Un verdadero cementerio lacustre descubrió en agosto de 1976 un vecino que buceaba en el Lago San Roque en Córdoba [...] (p. 247)

34 cadáveres en Buenos Aires entre el 3 y el 9 de abril de 1976, 8 cadáveres en San Telmo el 4 de julio, 10 cadáveres en el Río Luján el 9 de octubre, sirven de marco a las masacres del 20 de agosto que apilaron 30 muertos a 15 kilómetros de Campo de Mayo y 17 muertos en Lomas de Zamora. (p. 247)

A la luz de estos episodios cobra su significado final la definición de la guerra pronunciada por uno de sus jefes: "la lucha que libramos no reconoce límites morales ni naturales, se realiza más allá del bien y del mal." (p. 249) 
Esse conjunto de episódios que não aparecem encadeados por uma seqüência lógica vai ser arrematado pela citação dessa frase do teniente coronel Hugo Pascarelli, numa reportagem do jornal La Razón: "La lucha que libramos no reconoce límites morales ni naturales, se realiza más allá del bien y del mal“. A frase, pela construção anterior, adquire um sentido claro e se constitui em confissão de culpa.

Mas são o quinto e o sexto itens que condensam um diagnóstico e perspectiva programática da ditadura. É neles que, além de descrever e quantificar a rápida deterioração das condições de vida das grandes maiorias, Walsh aponta e denuncia os interesses econômicos nacionais e internacionais beneficiados:

[...] la vieja oligarquía ganadera, [...] la nueva oligarquía especuladora y [...] un grupo selecto de los monopolios internacionales encabezados por la ITT, la Esso, las automotrices, la US Steel, la Siemens, al que están ligados personalmente el ministro Martínez de Hoz y todos los miembros de su gabinete. (p. 252)

O autor assinala assim as razões que estariam por trás da ação repressiva, integrando sua eficácia à intenção da imposição de um modelo, aquele que vingará para além do período ditatorial e do qual a ditadura, com toda sua brutalidade, viria a ser apenas um instrumento necessário para a desarticulação de qualquer resistência à sua aplicação:

Estos hechos, que sacuden la conciencia del mundo civilizado, no son sin embargo los que mayores sufrimientos han traído al pueblo argentino ni las peores violaciones a los Derechos Humanos en que ustedes incurren. En la política económica de ese gobierno debe buscarse no sólo la explicación de sus crímenes, sino una atrocidad mayor que castiga a millones de seres humanos con la miseria 
Essa avaliação não coincidia em absoluto com a dos Montoneros, que apresentava a atividade repressiva das Forças Armadas como uma reação à escalada de ações militares da organização.

A última frase da carta torna explícita a função puramente retórica do destinatário assim nomeado:

\footnotetext{
Estas son las reflexiones que en el primer aniversario de su infausto gobierno he querido hacer llegar a los miembros de esa Junta, sin esperanza de ser escuchado, con la certeza de ser perseguido, pero fiel al compromiso que asumí hace mucho tiempo de dar testimonio en momentos difíciles. (p. 253)
}

A assinatura arrematada pelo número de documento sublinha a recuperação da autoria de seus textos que Walsh empreende com as cartas pessoais. De alguma maneira, a escolha dessa forma é uma reconciliação com a condição de intelectual, quando ser intelectual não é assumido já como um privilégio e sim como uma responsabilidade "em momentos difíceis". Com esta escolha pela forma "subalterna" e ao mesmo tempo pessoal, o escritor elude o papel de representante ou porta-voz daqueles que não têm voz. Eram formas que Walsh considerava adequadas para um momento em que as grandes massas não reconheciam direções e recuavam para posições defensivas. Então, ele achava que convinha falar no próprio nome, e não como representante, e estimular nos outros também a ousadia de falar também em seu próprio nome. Isto era refazer o caminho já percorrido no período de 1956 a 1973. Walsh pensava que, longe de empreender uma ofensiva, era preciso voltar às práticas da resistência, como 
registra nos Los documentos de polêmica com a direção montonera:

Hay que ser más modesto. Nosotros tenemos que resistir junto con el pueblo a la dictadura. ${ }^{16}$

[...] en la práctica sucede que nuestra teoria ha galopado kilómetros adelante de la realidad. Cuando eso ocurre, la vanguardia corre el riesgo de convertirse en la patrulla perdida. ${ }^{167}$

Esto no significa que El Partido vaya a renunciar a sus objetivos estratégicos, su propuesta intermedia de Movimiento Montonero, su propuesta final de poder socialista, su programa de largo plazo, en suma; significa poner la correcta distancia entre esos objetivos lejanos y la dura realidade actual, que no permite a las masas ni siquiera pensar el poder, sino resistir para sobrevivir. ${ }^{168}$

As cartas são, assim como Operación Masacre foi no seu momento, um ponto de inflexão na escrita de Walsh. Se depois de 1956 o autor tende a abandonar a literatura policial, a incluir as vozes subalternas e a diluir a autoria dos seus textos, há, junto com as cartas, a retomada da autoria, da produção ficcional e a inclusão da voz do outro numa forma um tanto nova. Já não se trata de incluir a voz do sobrevivente do qual o autor é mediador. Trata-se, agora, de considerar o outro como portador de uma verdade sobre o próprio autor. Isto é, o autor já não se apresenta, como dizia em Esa mujer, como "una arrastada, amarga, olvidada sombra"169. Aparentemente, a procura da superação da solidão do intelectual não conduziu Walsh à diluição da autoria, como ele supunha, e sim a um tipo de ação política que exigiu uma forma particular da escrita.

166 WALSH, Rodolfo. "Los documentos". In: BASCHETTI, Roberto. Rodolfo Walsh, vivo. Buenos Aires: de la Flor, 1994, p. 212.

167 WALSH, Rodolfo. "Los documentos". In: BASCHETTI, Roberto. Rodolfo Walsh, vivo. Ed. cit., p. 223.

168 WALSH, Rodolfo. "Los documentos". In: BASCHETTI, Roberto. Rodolfo Walsh, vivo. Ed. cit., p. 224.

169 WALSH, Rodolfo. "Esa mujer". In: Los oficios terrestres. Ed. cit., p. 10. 
A leitura da Carta abierta a la junta militar parece, mais que outros textos do autor, falar às novas gerações sobre o momento atual, sobre os acontecimentos que propiciaram os posteriores rumos da história argentina. E também parece jogar luz sobre os diferentes papéis ocupados pelos intelectuais perante a ditadura, apresentando um lugar diferenciado para o intelectual que foi Walsh. Mas o que ainda vem sendo pensado é como as formas literárias escolhidas pelo autor se articulam com a possibilidade de diagnosticar, prever e comunicar a partir desse lugar que ele "fez" para si como intelectual. Essas formas configuram também uma poética que aponta caminhos para uma literatura e um jornalismo militante. 


\title{
CONSIDERAÇÕES FINAIS
}

André Gide fala da relação entre obra e autor nestes termos: "Quis indicar, nesta Tentative Amoureuse, a influência do livro sobre aquele que o escreve e durante a sua própria realização. Pois, ao sair de nós, muda-nos, modifica a marcha de nossa vida $[\ldots]^{p 170}$. Trinta anos depois, escreve:

\begin{abstract}
Parece-me que cada um dos meus livros foi menos o produto de uma disposição interior nova do que, pelo contrário, a sua causa e a provocação primeira dessa disposição de alma e de espírito na qual devia manter-me para levar a bom termo a elaboração. Gostaria de exprimir isso de uma maneira mais simples: que o livro, logo que é concebido, dispõe inteiramente de mim, e que para ele, tudo em mim, até ao mais profundo do eu, é seu instrumento. Já não tenho outra personalidade senão aquela que convém a essa obra $[\ldots] .{ }^{171}$
\end{abstract}

Blanchot reflete a propósito desta afirmação:

\begin{abstract}
Não escrevemos segundo o que somos; somos segundo o que escrevemos. Mas donde vem o que é escrito: ainda de nós: de uma possibilidade de nós próprios que se descobriria e se afirmaria unicamente pelo trabalho literário? Todo trabalho nos transforma, toda ação realizada por nós é ação sobre nós: o ato que consiste em fazer um livro modificar-nos-ia mais profundamente? $E$ é realmente o próprio ato, então, o que há de trabalho, paciência e atenção nesse ato: Não é uma exigência mais original, uma mudança preliminar que talvez se concretize através da obra, à qual nos conduz, mas que, por uma contradição essencial, é não só anterior à sua concretização mas retrocede até ao ponto onde nada pode ser realizado? ${ }^{172}$
\end{abstract}

Sem me deter nas respostas que dá Blanchot a essas indagações, quero conferir como essa relação entre autor e obra é pensada por Walsh. Lembro aqui um trecho, já citado no trabalho, da pequena nota autobiográfica

170 GUIDE, André apud: BLANCHOT, Maurice. O espaço literário. Trad. Álvaro Cabral. Rio de Janeiro: Rocco, 1987, 85.

171 GUIDE, André apud: BLANCHOT, Maurice. O espaço literário. Ed. cit., p. 85-86.

172 GUIDE, André apud: BLANCHOT, Maurice. O espaço literário. Ed. cit., p. 86. 
de Walsh: "Operación Masacre cambió mi vida. Haciéndola comprendí que, además de mis perplejidades íntimas, existía un amenazante mundo exterior $^{\prime 173}$. Imediatamente, passa a relatar a sua viagem a Cuba e, mais à frente, ainda sobre o seu ofício de escritor:

En la hipótesis de seguir escribiendo, lo que más necesito es una cuota generosa de tiempo. Soy lento: he tardado quince años en pasar del mero nacionalismo a la izquierda; lustros en aprender a armar un cuento, a sentir la respiración de un texto; sé que me falta mucho para poder decir instantáneamente lo que quiero, en su forma óptima; pienso que la literatura es, entre otras cosas, un avance laborioso a través de la propia estupidez. ${ }^{174}$

Para Walsh a escrita é um espaço de reflexão, registro e preparação para a ação política. Mas ela é, também, ação política.

Em Walsh, a passagem dos policiais de enigma para o hard-boiled e daí para o abandono da literatura policial é sinal das mudanças profundas que se operavam em sua perspectiva, resultantes do seu trabalho investigativo. A troca do delegado Jiménez pelo delegado Laurenzi acontece junto com um deslocamento do foco narrativo de Daniel Hernández para o delegado, mas agora trata-se de um delegado fracassado. A investigação policial fracassa, o detetive amador fracassa, as certezas diluem-se. $O$ xadrez e sua beleza geométrica são tratados com ironia. A verdade pode até ser encontrada, mas nunca em tempo para evitar o crime ou para fazer justiça. E, quando se consegue alguma forma de justiça, ela nunca se alcança pela via legal. Daniel Hernández, alter ego do autor, deixa de 
formular a verdade, ele apenas registra, ao mesmo tempo em que as investigações levam Walsh a recolher testemunhos e registrá-los.

O abandono completo do subgênero coincide com a perda das ilusões na justiça do Estado, seja o governo militar ou civil, depois do acontecido com seu trabalho no caso do assassinato do advogado Satanovsky. O escritor passa a perceber o crime como dado orgânico do sistema. A última investigação, a da morte do sindicalista Rosendo García, já não é levada adiante com a intenção de vencer um processo legal e sim de contribuir ao reagrupamento das forças sindicais em torno a uma nova direção mais combativa. E, para realizar esse trabalho, conta com uma ampla rede de quadros militantes.

Mas, entre a investigação do caso Satanovsky e a da morte de Rosendo García, Walsh produz um conjunto de contos. Nesse período, ele investe energia no projeto de se tornar escritor e publicar uma "novela seria". Nesses contos, porém, o autor reflete sobre a possibilidade de criar uma máquina narrativa, pensando na escrita como um ofício ao alcance dos "comuns", nos que supõe haver astúcias que permitem produzir histórias divergentes das hegemônicas.

Percebe que a dominação e a violência de Estado é mediada pela linguagem. Ainda a violência física, para ser eficiente, precisa ser inscrita na memória de maneira simbólica como uma ameaça para os sobreviventes. A redução das vítimas à carne destroçada funciona como uma antecipação 
exemplar para os sobreviventes. O caminho inverso é a ação política que, pela reinscrição da violência operada sobre os corpos dentro de um relato de resistência, muda o sentido do episódio traumático, transformando vítimas em militantes, objetos da violência em sujeitos da história.

Para esse projeto de escrita precisa procurar a forma adequada. A reflexão sobre a eficiência de Operación Masacre permitiu a Walsh traçar algumas linhas de ação: formas literárias e formas de intervenção política. A apropriação pelo texto da voz do não letrado corre junto com a perda de confiança na capacidade do escritor para representar a totalidade e no papel do intelectual para agir na representação do coletivo. A dificuldade de escrever o romance e o adiamento desse projeto em favor dos contos no período que vai de 1961 a 1967 parece resultar dessa tensão. A forma breve do conto aproxima-se do relato oral, da confidência, da história fragmentada que se partilha com o interlocutor solidário com a intenção de que este lhe complete o sentido. E por fim a própria temática dos contos parece um comentário pessimista a propósito de qualquer projeto pessoal e diferenciado do intelectual, como em Esa mujer.

O último conto publicado, Un oscuro día de justicia, foi escrito após a morte de Che Guevara. Parece condensar as opiniões de Walsh em 1967 a propósito do fracasso do indivíduo que age como representante das maiorias. O "tío Malcolm" do relato é o "herói individual" que fracassa por isso mesmo, por agir sozinho em representação de "el pueblo". Walsh abandona a publicação daqueles textos que considera literatura num sentido estrito e se 
lança à tarefa de construir o periódico CGT primeiro e o Semanario Villero depois. Ambos são projetos coletivos de escrita militante. Neles, a função de Walsh é de direção, coordenação e formação. O assassinato de Rosendo García é investigado junto com o coletivo de imprensa da central sindical. A partir de então, deixa de assinar o que escreve e passa a fazer parte do setor de comunicações e de inteligência das FAP $^{175}$ primeiro e de Montoneros depois.

Quando a organização Montoneros abandona a atividade de massas em favor da atividade militar, Walsh entra em polêmica com a direção. Questiona-a por pretender agir como representante de uma maioria que não Ihe delegou qualquer mandato para isso. Nesse período de fim de 1976 e começo de 1977, em plena repressão, o escritor volta a assinar seus escritos. Desta vez, com a opção pela forma das "cartas pessoais", parece querer recuperar procedimentos adotados durante suas investigações, quando interpelava os envolvidos. Mas essa escolha também diz respeito a um novo lugar para si como escritor, como intelectual. Opta por um gênero de escrita que, como nos seus contos Cartas e Nota al pie, é aquele ao qual os "comuns" podem aspirar. Ao mesmo tempo em que assina, essa autoria não o coloca numa posição privilegiada; primeiro, porque, nesse momento, a assinatura pode atrair a repressão para sua pessoa; mas também porque nessas cartas estimula outros a fazeem como ele, mesmo não sendo escritores.

175 Fuerzas Armadas Peronistas. 
A recuperação da autoria não era alheia à retomada da produção literária. Sabemos por Lilia Ferreyra que, na mesma noite em que escreveu a Carta abierta a la junta militar, na véspera de seu desaparecimento, terminou de escrever um dos contos em que pensava desdobrar o material que havia guardado para seu romance ${ }^{176}$. A opção pelas formas da carta pessoal e do conto parecem indicar um novo lugar para o militante e o escritor, assim como a opção por permanecer na Argentina, mesmo depois da morte da sua filha María Victoria, de Paco Urondo e de outros companheiros próximos, ou talvez essas mortes tenham ajudado a tomar essa decisão. Walsh não quer agir como representante dos outros. Seu gesto é aquele do homem "que se anima" a um "acto de libertad" e com ele pretende interpelar os outros a fazer a mesma coisa. Não há delegação de mandato. É nesses termos que escreve a Carta abierta a la junta militar.

No conto Juan se iba por el río, relatado por Lilia Ferreyra ${ }^{177}$, que escreveu na véspera de seu desaparecimento, o protagonista, aproveita uma excepcional maré baixa no Rio de la Plata para atravessá-lo a cavalo em direção ao Uruguai. O conto acaba quando Juan está no meio do trajeto e a maré começa a retornar. Assim como o "tío Malcolm", mas por motivos diferentes, o protagonista do último conto também permaneceu, literalmente, um "héroe a mitad de camino"178. Até o momento derradeiro, o conto foi o

176 FERREYRA, Lilia. "Rigor e inteligencia en la vida de Rodolfo Walsh". In: BASCHETTI, Roberto (org.). Rodolfo Walsh, vivo. Ed. cit., p. 195-201.

177 FERREYRA, Lilia. "Dos lectores". In: Página/12, Buenos Aires, 9/jan./2006, contracapa. Disponível em: < http://www.pagina12.com.ar/diario/contratapa/13-61457-200601-09.html>. Acesso em: 28 out. 2008 às 18:08.

178 WALSH, Rodolfo. "Un oscuro día de justicia". In: Cuentos. Ed. cit., p. 59. 
lugar da reflexão. A inscrição desse gesto mínimo no espaço subalterno da carta pessoal que só podia circular em pequena escala, em cópias feitas com papel carbono e por correio, era uma aposta de risco. Mesmo assim, Walsh achava que valia a pena. Ao suporte argumentativo do texto, o autor acrescentava seu próprio corpo, ainda desaparecido junto com seus escritos inéditos, entre os quais Juan se iba por el río. 


\section{REFERÊNCIAS BIBLIOGRÁFICAS}

\section{Obras do autor}

WALSH, Rodolfo."La máquina del bien y del mal". In: LUGONES, Pirí (org.). Los diez mandamientos. Buenos Aires: Jorge Álvarez, 1966, p. 78-82. . "Quién mató a Rosendo?”. In: CGT no 3 - ano I. Buenos Aires, 16 de maio de 1968, p. 2. . "La aventura de las pruebas de imprenta". In: Obra literaria completa. 2ª . Edição. México: Siglo Veintiuno, 1985, p. 11-70 . . "Variaciones en rojo". In: Obra literaria completa. 2ª Edição. México: Siglo Veintiuno, 1985, p. 71-112 . . "Asesinato a distancia". In: Obra literaria completa. 2‥ Edição. México: Siglo Veintiuno, 1985, p. 113-160. . "La granada". In: La granada/La batalla. Buenos Aires: de la Flor, 1988, p. 5-63. . "Irlandeses detrás de un gato". In:Cuentos. Buenos Aires: Biblioteca Página/12, 1993, p. 13-30. 
."Los oficios terrestres". In:Cuentos. Buenos Aires:

Biblioteca Página/12, 1993, p. 31-40.

."Un oscuro día de justicia". In: Cuentos. Buenos Aires:

Biblioteca Página/12, 1993, p. 41-60.

. "El violento oficio de escitor". In: BASCHETTI, Roberto.

Rodolfo Walsh, vivo. Buenos Aires: de la Flor, 1994, p. 30-32.

"Hoy es imposible en la Argentina hacer literatura

desvinculada de la política". In: BASCHETTI, Roberto. Rodolfo Walsh, vivo.

Buenos Aires: de la Flor, 1994, p. 62-74.

. "Carta a Vicky". In: BASCHETTI, Roberto (org.). Rodolfo

Walsh, vivo. Buenos Aires: de la Flor, 1994, p. 186-187.

. "Carta a mis amigos". In: BASCHETTI, Roberto (org.).

Rodolfo Walsh, vivo. Buenos Aires: de la Flor, 1994, p. 188-191.

. "Diciembre 29" . In: BASCHETTI, Roberto (org.). Rodolfo

Walsh, vivo. Buenos Aires: de la Flor, 1994, p. 192-194.

. "Los documentos". In: BASCHETTI, Roberto. Rodolfo

Walsh, vivo. Buenos Aires: de la Flor, 1994, p. 206-240. 
. "Carta abierta a la junta militar". In: BASCHETTI, Roberto.

Rodolfo Walsh, vivo. Buenos Aires: de la Flor, 1994, p. 241-253.

. "Papeles Personales". In: Ese hombre y otros papeles

personales. Buenos Aires: Seix Barral, 1996.

. "Nota al pie". In: Un kilo de oro. 3ạ. Edição. Buenos Aires:

de la Flor, 1997, p. 69-96.

. "Cartas". In: Un kilo de oro. 3‥ Ed. Buenos Aires: de la

Flor, 1997, p. 9-51.

. ¿Quién mató a Rosendo? 7ª . Edição. Buenos Aires: de la

Flor, 1997.

. Caso Satanowsky. Buenos Aires: de la Flor, 1997.

. "Mensaje a Pérez Griz". In: Caso Satanowsky. 3ª. Ed.

Buenos Aires: de la Flor, 1997, p. 255-260.

. "El violento oficio de escritor". In: LINK, Daniel (org.).

Rodolfo Walsh. El violento oficio de escribir. Obra periodística 1953-1977. 2ª̣.

Edição. Buenos Aires: Planeta, 1998.

. "2-0-12 no vuelve". In: LINK, Daniel (org.). Rodolfo Walsh. 
El violento oficio de escribir. Obra periodística 1953-1977. 2a. Edição. Buenos Aires: Planeta, 1998, p. 10-14.

. "Aquí cerraron sus ojos". In: LINK, Daniel (org.). Rodolfo

Walsh. El violento oficio de escribir. Obra periodística 1953-1977. 2ª . Edição.

Buenos Aires: Planeta, 1998, p. 15-18.

. "Los métodos del FBI". In: LINK, Daniel (org.). Rodolfo

Walsh. El violento oficio de escribir. Obra periodística 1953-1977. 2ª . Edição.

Buenos Aires: Planeta, 1998, p. 73-78.

. "La Argentina ya no toma mate". In: LINK, Daniel (org.).

Rodolfo Walsh. El violento oficio de escribir. Obra periodística 1953-1977. 2ª .

Edição. Buenos Aires: Planeta, 1998, p. 122-130.

. "Kimonos en la tierra roja". In: LINK, Daniel (org.). Rodolfo

Walsh. El violento oficio de escribir. Obra periodística 1953-1977. 2ª . Edição.

Buenos Aires: Planeta, 1998, p. 131-134.

"El matadero". In: LINK, Daniel (org.). Rodolfo Walsh. El violento oficio de escribir. Obra periodística 1953-1977. 2a. Edição. Buenos Aires: Planeta, 1998, 144-149.

. "Las carnes que salen del frío". In: LINK, Daniel (org.).

Rodolfo Walsh. El violento oficio de escribir. Obra periodística 1953-1977. 2ª 
Edição. Buenos Aires: Planeta, 1998, p. 150-156.

. "Magos de agua dulce". In: LINK, Daniel (org.). Rodolfo

Walsh. El violento oficio de escribir. Obra periodística 1953-1977. 2ª . Edição. Buenos Aires: Planeta, 1998, p. 157-161.

. "La secta del gatillo alegre". In: LINK, Daniel (org.).

Rodolfo Walsh. El violento oficio de escribir. Obra periodística 1953-1977. 2ª

Edição. Buenos Aires: Planeta, 1998.

. “La sombra de un pájaro'”. In: Cuentos para tahúres y

otros relatos policiales. 3ạ. Edição. Buenos Aires: de la Flor, 1999, p. 17-62.

. "Tres portugueses bajo un paraguas (Sin contar el

muerto)". In: Cuentos para tahúres y otros relatos policiales. 3ª . Edição.

Buenos Aires: de la Flor, 1999, p. 63-70.

"Las tres noches de Isaías Bloom". In: Cuentos para

tahúres y otros relatos policiales. 3ª . Edição. Buenos Aires: de la Flor, 1999, p. 71-83.

"Simbiosis". In: Cuentos para tahúres y otros relatos

policiales. 3ạ. Edição. Buenos Aires: de la Flor, 1999, p.103-122.

"Transposición de jugadas". In: Cuentos para tahúres y 
otros relatos policiales. 3ㄹ. Edição. Buenos Aires: de la Flor, 1999, p. 85-102. . "En defensa propia". In: Cuentos para tahúres y otros relatos policiales. 3ª . Edição. Buenos Aires: de la Flor, 1999, p. 147-158. . "Los ojos del traidor". In: WALSH, Rodolfo. Cuento para tahúres y otros relatos policiales. 3ª . Ed. Buenos Aires: de la Flor, 1999, p. 169-178.

Operación masacre. 21‥ Ed. Buenos Aires: de la Flor, 2000. . "Nota autobiográfica". In: LAFFORGUE, Jorge et ALL. Textos de y sobre Rodolfo Walsh. Buenos Aires: Alianza, 2000, p. 241-242. . "El ajedrez y los dioses". In: LAFFORGUE, Jorge et ALL. Textos de y sobre Rodolfo Walsh. Buenos Aires: Alianza, 2000, p. 243-244. . "Zugzwang". In: LAFFORGUE, Jorge et ALL. Textos de y sobre Rodolfo Walsh. Buenos Aires: Alianza, 2000, p. 250-258. . "Claroscuro del subibaja". In: LAFFORGUE, Jorge et ALL. Textos de y sobre Rodolfo Walsh. Buenos Aires: Alianza, 2000, p. 258-259. "Esa mujer". In: Los oficios terrestres. 4ª Edição. Buenos 
Aires: de la Flor, 2000, p. 9-20.

"Fotos". In: Los oficios terrestres. 4⿳a . Edição. Buenos

Aires: de la Flor, 2000, p. 21-53.

. "El soñador". In: Los oficios terrestres. 4a . Edição. Buenos

Aires: de la Flor, 2000, p. 55-69.

. "Imaginaria". In: Los oficios terrestres. 4a․ Edição. Buenos

Aires: de la Flor, 2000, p. 63-69.

. "Corso". In: Los oficios terrestres. 4ª . Edição. Buenos

Aires: de la Flor, 2000, p. 97-99.

. "Lobo estás?". In: Ese hombre y otros papeles

personales. Buenos Aires: de la Flor, 2007, p. 141-146.

\section{Bibliografia geral}

ADOUE, Silvia; DELAMUTA, Karen García; e ENGEL, Priscila. "Cem anos de solidão e o massacre de Aracataca". Revista Espaço Acadêmico, n74, jul/2007, ano VII. Disponível em:

<http://www.espacoacademico.com.br/074/74adoue.htm>, Acesso em: 26 out. 2008 às $12: 52$ 
AGAMBEN, Giorgio. "El testigo" e “El ‘musulmán”'. In: Lo que queda de Auschwitz. El archivo y el testigo. Homo Saccer III. Trad. Antonio Gimeno Cuspinera. Valencia: Pre-Textos, 2000, p. 13-40 e 41-90.

ALABARCES, Pablo. "Dialogismos y géneros populares". In: LAFFORGUE, Jorge e outros. Textos de y sobre Rodolfo Walsh. Buenos Aires: Alianza, 2000, p. 29-38.

AMAR SÁNCHEZ, Ana Maria. "La propuesta de una escritura. (En homenaje a Rodolfo Walsh)". In: BASCHETTI, Roberto. Rodolfo Walsh, vivo. Buenos Aires: de la Flor, 1994, p. 205-218.

$$
\text { . "El sueño eterno de justicia". In: }
$$

LAFFORGUE, Jorge et ALL. Textos de y sobre Rodolfo Walsh. Buenos Aires: Alianza, 2000, p. 205-218.

Anônimo. "La cólera de un particular". In: AA.VV. El libro de los autores. Trad. Rodolfo Walsh. Buenos Aires: de la Flor, 1967.

ARLT, Roberto. Aguafuertes porteñas. Losada, Buenos Aires, 1996. . Los siete locos. 13ª Edição. Buenos Aires: Losada, 1997.

ARROSAGARAY, Enrique. Rodolfo Walsh en Cuba. Agencia Prensa Latina, militancia, ron y criptografía. Buenos Aires: Catálogos, 2004. 

. Rodolfo Walsh, de dramaturgo a guerrillero.

Buenos Aires: Catálogos, 2006.

BARNET, Miguel. Biografia de um cimarrón. Buenos Aires: Centro Editor de América Latina, 1977.

BAYER, Osvaldo. Los vengadores de la Patagonia Trágica. Buenos Aires: Galerna, 1972-1974.

BENJAMIN, Walter. "Teses sobre a Filosofia da História" in: BENJAMIN, Walter. Walter Benjamin. Trad. Flávio R. Kothe. São Paulo: Ática, 1991.

BIOY CASARES, Adolfo. La invención de Morel. Buenos Aires: La Nación, 2000.

BLANCHOT, Maurice. O espaço literário. Trad. Álvaro Cabral. Rio de Janeiro: Rocco, 1987.

BONASSO, Miguel. Diario de un clandestino. Buenos Aires: Planeta, 2000. Recuerdos de la muerte. 5a․ Edição. Buenos Aires:

Planeta, 2003.

BORGES, Jorge Luis. "La casa de Asterión”. In: El Aleph. Buenos Aires: 
Emecé, 1957, p. 67-70.

"La muerte y la brújula". In:. Ficciones. Madrid: Alianza,

1998, p.153-172.

. "Pierre Ménard, autor del Quijote". In: Ficciones.

Madrid: Alianza, 1998, p. 47-59.

. "Tema del traidor y el héroe". In: Ficciones. Madri:

Alianza, 1998, p. 146-152.

. "Tema del traidor y el héroe". In: Ficciones. Madri:

Alianza, 1998, p. 199-216.

. Historia universal de la infamia. Madrid: Alianza, 2002.

e BIOY CASARES, Adolfo. "La fiesta del monstruo". In:

OLGuíN, Sergio (org.). Perón Vuelve. Cuentos sobre peronismo. Buenos

Aires: Norma, 2000, p. 41-59.

BRECHT, Berthold. "Cinco maneiras de dizer a verdade". Trad. Florian Geyer.

Revista Margem Esquerda nº 8, novembro de 2006, p. 193-206.

BURGOS, Elizabeth. Me llamo Rigoberta Menchú y así me nació la conciencia. 19a ed. México: Siglo XXI, 2005. 
BUSTOS, Ciro. El Che quiere verte. Buenos Aires: Vergara, 2007.

CANÉ, MIGUEL. Juvenilia. Buenos Aires: Eudeba, 1968.

CAPOTE, Truman. A sangre fría. Trad. Fernando Rodríguez. Barcelona: Bruguera, 1979.

CERVANTES, Miguel de. "Que trata del curioso discurso que hizo don Quijote de las armas y las letras". In: El ingenioso hidalgo don Quijote de La Mancha. Buenos Aires: Planeta, 2000, p. 410-414.

CERTEAU, Michel de. A invenção do cotidiano: 1. artes de fazer. Trad. Ephraim Ferreira Alves. 5a. Ed. Petrópolis: Vozes, 2000. ; GIARD, Luce e MAYOL, Pierre. A invenção do cotidiano: 2. Morar, cozinhar. Trad. Ephraim Ferreira Alves e Lúcia Endlich Orth. Petrópolis: Vozes, 1997.

CONAN DOYLE, Adrian e DICKSON CARR, John. "La aventura de los siete relojes". Trad.: Rodolfo Walsh. In: Leoplán, XIX, 454, 20/5/1953; p. 75-79. "La aventura de los jugadores de cera (Un Nuevo capítulo del sensacional regreso de Sherlock 
Holmes)". Trad. Rodolfo Walsh. In: Leoplán, XX, 480, 16/6/1954; p. 66 e ss.

CONAN DOYLE, Sir Arthur. "A aventura dos três estudantes". In: . A volta de Sherlock Holmes. Trad. Lígia Junqueira. $4^{\text {a }}$. Edição. São Paulo: Melhoramentos, 197-?.

. Um estudo em vermelho. Trad. Jean Melville.

São Paulo: Martin Claret, 2001.

COOPER, Duff. "Operation Heartbreak". In: MONTAGU, Ewen e COOPER, Duff. The man who never was - Operation Heartbreak. Kent: Spellmount, 2003, p. 1-103.

CORTÁZAR, Julio. "Torito". In: Cuentos Completos, Buenos Aires: Alfaguara, 1996.

CUNHA, Euclides da. Os Sertões (Campanha de Canudos). 2ª Ed. São Paulo: Ateliê, Imprensa Oficial do Estado, Arquivo do Estado, 2001.

DE MARCO, Valéria. "A literatura de testemunho e a violência de Estado". In: Lua Nova - Revista de cultura e política oํ 62/ 2004.

DISCÉPOLO, Armando."Mustafá". In: Revista Teatral. Buenos Aires: 1921, 340. 
ECHEVERRÍA, Esteban. El matadero. Buenos Aires: Plaza Dorrego, 2003.

FERNÁNDEZ, Macedonio. Museo de la novela de la Eterna. Madrid:

Archivos, CSIC, 1993.

FERREYRA, Lilia. "Rigor e inteligencia en la vida de Rodolfo Walsh". In:

BASCHETTI, Roberto (org.). Rodolfo Walsh, vivo. Buenos Aires: de la Flor, 1994, p. 195-201.

"Dos lectores". Jornal Página/12, Buenos Aires, 9/jan./2006, contracapa. Disponível em: < http://www.pagina12.com.ar/diario/contratapa/13-614572006-01-09.html>. Acesso em: 28 out. 2008 às 18:08.

FERRO, Roberto. "Prólogo". In: WALSH, Rodolfo. Caso Satanowsky. Buenos Aires: de la Flor, 1997, p 7-14.

. "Escritura periodística y poderes políticos". In: WALSH,

Rodolfo. El caso Satanowsky. Buenos Aires: de la Flor, 1997, p. 207-219.

."Operación Masacre': investigación y escritura". In:

LAFFORGUE, Jorge et ALL. Textos de y sobre Rodolfo Walsh. Buenos Aires: Alianza, 2000, p. 139-166.

FORD, Aníbal. "Ese hombre. In: LAFFORGUE, Jorge (org.). Textos de y sobre Rodolfo Walsh. Buenos Aires: Alianza, 2000, p. 11. 
FOUCAULT, Michel. "Los intelectuales y el poder". In: Microfísica del poder. Trad. Julia Varela e Fernando Álvarez-Uría. 3ª Edição. Madrid: La Piqueta, 1992.

GARCÍA, Romina. "Novela de no ficción o testimonio: uma revisión sobre el género". In: BOCHINO, Adriana A.; GARCÍA, Romina e MERCÈRE, Emiliana. Rodolfo Walsh - del policial al testimonio. Mar del Plata: Estanislao Balder, 2004, p. 93-118.

GILMAN, Claudia. Entre la pluma y el fusil. Debates y dilemas del escritor revolucionario en América Latina. Buenos Aires: Siglo XXI, 2003.

GONZÁLEZ, Horacio. Reflexiones en torno al entrecruzamento de la sociología com la investigassem periodística y la estructura de la narrativa policial. Buenos Aires: mime, s/d.

GONZÁLEZ TUÑóN, Enrique. Camas desde un peso. Buenos Aires: Ameghino, 1998.

HERNÁNDEZ, José. Martín Fierro. Buenos Aires: Terra, 2001.

IMPERATORE, Adriana. "Voces, prácticas y apropiaciones de lo popular en la ficción de Walsh. In: ZUBIETA, Ana M. (comp.): Letrados iletrados. Apropiaciones y representaciones de lo popular en la literatura. Buenos Aires: 
Eudeba, 1999, p. 169-186.

JOUVET, Héctor. "Entrevista". Lucha armada en la Argentina no 2 trimestre março-maio 2005, p. 51-59, Buenos Aires.

LAFFORGUE, Jorge. "Epílogo provisorio". In: e outros.

Textos de y sobre Rodolfo Walsh. Buenos Aires: Alianza, 2000.

LEWIS, Oscar. Los hijos de Sánchez: autobiografía de una familia mexicana. 4. ed. México: Mortiz, 1965.

LINK, Daniel (org.). Rodolfo Walsh. El violento oficio de escribir. Obra periodística 1953-1977. 2ª . Edição. Buenos Aires: Planeta, 1998.

MARTÍNEZ, Tomás Eloy. Santa Evita. Trad. Sérgio Molina. São Paulo: Companhia das Letras, 1996.

. La pasión según Trelew. Buenos Aires: Aguilar, 2004.

MASETTI, Jorge. Los que luchan y los que lloran. Buenos Aires: J. Alvarez, 1969.

MONTAGU, Ewen. "The man who never was". In: MONTAGU, Ewen e 
COOPER, Duff. The man who never was - Operation Heartbreak. Kent: Spellmount, 2003, p. 105-200.

MORENO, Maria. Sobre La "Carta a Vicky". Buenos Aires: mime, s/d.

PAMPILLO, Gloria e URTASUN, Marta. "'Operación Masacre' y las estrategias de la persuasión". In: LAFFORGUE, Jorge et ALL. Textos de y sobre Rodolfo Walsh. Buenos Aires: Alianza, 2000, p. 167-185.

PENNA, João Camillo. "Este corpo, esta dor, esta fome: notas sobre o testemunho Hispano-Americano". In: SELIGMANN-SILVA, Márcio (org.). História, Memória, Literatura. O testemunho na Era das Catástrofes. Campinas: Unicamp, 2003, p. 299-354.

PIGLIA, Ricardo. Crítica y Ficción. Buenos Aires: Fausto, 1993 . "Tesis sobre el cuento". In: Crítica y Ficción. Buenos Aires: Fausto, 1993, p. 73-80.

A cidade ausente. Trad. Sergio Molina. $2^{\mathrm{a}}$. Ed. São Paulo: lluminuras, 1997. . La ficción paranoica. Buenos Aires: Universidad de las Madres de Plaza de Mayo, I Seminario de Análisis Crítico de la realidad argentina 1984-1999, 25 set. 1999 (informação verbal). 
"Tres propuestas para el próximo milênio (y cinco

dificultades)". In: e ROZITCHNER, Leon. Tres propuestas

para el próximo milenio (y cinco dificultades)/Mi Buenos Aires querida.

Buenos Aires: 2001, p. 5-42.

. “Qué va a ser de ti?”. In: Radar, suplemento de Página/12,

Buenos Aires, 23/12/2001, p. 8.

PORTANTIERO, Juan Carlos; URONDO, Francisco e WALSH, Rodolfo. "La

literatura argentina del siglo XX". In: BASCHETTI, Roberto (org.). Rodolfo

Walsh, vivo. Buenos Aires: de la Flor, 1994, p. 33-61.

RANDALL, Margaret. “¿Qué es y cómo se hace un testimonio?”. In: Revista de crítica literaria latinoamericana $\mathrm{n}^{\circ}=36$. Lima, $2^{\circ}$. Semestre de 1992, p. 21 45.

Revista de crítica literaria latinoamericana ํㅜ 36. Lima, 2ํ. Semestre de 1992.

ROJO, Ricardo. Mi amigo el Che. Buenos Aires: Jorge Alvarez, 1968.

ROMANO, Eduardo. "Modelos, géneros y medios en la iniciación literaria de Rodolfo J. Walsh". In: LAFFORGUE, Jorge et ALL. Textos de y sobre Rodolfo Walsh. Buenos Aires: Alianza, 2000, p. 73-98. 
SABATO, Ernesto. El túnel. Buenos Aires: Seix Barral, 1951.

SARLO, Beatriz. "Una alucinación dispersa en agonía”. In: Punto de Vista n 21. Agosto de 1984, p. 1-4.

SARLO, Beatriz. "El país de no ficción”. Zona, Buenos Aires, 26 Set. 1999. Disponível em: <http://www.clarin.com/suplementos/zona/1999/09/26/i-00702e.htm>. Acesso em: 26 out.2008 às 12:36.

SARMIENTO, Domingo Faustino. Facundo. Buenos Aires: Nautilus, 1976.

SELIGMANN-SILVA, Márcio. "A história como trauma" in: NETROVSKI, Arthur e (orgs.). Catástrofe e Representação. São

Paulo: Escuta, 2000, p. 73-98. . "Literatura e trauma: um novo paradigma" in: Rivista di Studi Portghesi e Brasiliani n III, 2001, p

SKLODOWSKA, Elzbieta. Testimonio hispanoamericano. Historia, teoría, poética. Nova York: Peter Lang, 1991.

VACAREZZA, Alberto. El conventillo de la Paloma. Buenos Aires. Ediciones del Carro de Tespis. 1965.

VERBITSKY, Horacio. Rodolfo Walsh y La prensa clandestina. 1976-1978. Buenos Aires: Urraca, 1985, p. 11. 
VIÑAS, David. Los dueños de la tierra. 8ª Edição. Buenos Aires: Lorraine, 1974.

VIÑAS, David. "Rodolfo Walsh, el ajedrez y la guerra". El ortiba. Disponível em: <http://www.elortiba.org/walsh.html>. Acesso em: 28 out. 2008 às 16:51.

WHITEHEAD, Don. La historia del F.B.I. Trad. Rodolfo Walsh. Buenos Aires: Sopena, 1958. 
Anexos 


\section{CARTA A VICKI}

$1 / 10$

Querida Vicki.

La noticia de tu muerte me llegó hoy a las tres de la tarde. Estábamos en reunión...cuando empezaron a transmitir el comunicado. Escuché tu nombre, mal pronunciado, y tardé un segundo en asimilarlo. Maquinalmente empecé a santiguarme como cuando era chico. No terminé ese gesto. El mundo estuvo parado ese segundo.

Después les dije a Mariana y a Pablo: -Era mi hija. Suspendí la reunión.

Estoy aturdido. Muchas veces lo temía. Pensaba que era excesiva suerte, no ser golpeado, cuando tantos otros son golpeados. Si, tuve miedo por vos, como vos tuviste miedo por mi, aunque no lo decíamos. Ahora el miedo es aflicción. Se muy bien por qué cosas has vivido, combatido. Estoy orgulloso de esas cosas. Me quisiste, te quise. El día que te mataron cumpliste 26 años. Los últimos fueron muy duros para vos. Me gustaría verte sonreír una vez más. No podré despedirme, vos sabés por qué. Nosotros morimos perseguidos, en la oscuridad. El verdadero cementerio es la memoria. Ahí te guardo, te acuno, te celebro y quizá te envidio, querida mía. 
Hablé con tu mamá. Está orgullosa en su dolor, segura de haber entendido tu corta, dura, maravillosa vida.

Anoche tuve una pesadilla torrencial, en la que había una columna de fuego, poderosa pero contenida en sus límites, que brotaba de alguna profundidad.

Hoy en el tren un hombre decía: -Sufro mucho. Quisiera acostarme a dormir y despertarme dentro de un año. Hablaba por él, pero también por mi. 


\section{CARTA A MIS AMIGOS}

Hoy se cumplen tres meses de la muerte de mi hija, María Victoria, después de un combate con las fuerzas del Ejército. Se que la mayoría de aquellos que la conocieron la lloraron. Otros que han sido mis amigos o me han conocido de lejos, hubieran querido hacerme llegar una voz de consuelo. Me dirijo a ellos para agradecerles, pero también para explicarles cómo murió Vicki y por qué murió.

El comunicado del Ejército que publicaron los diarios no difiere demasiado, en esta oportunidad, de los hechos. Efectivamente, Vicki era Oficial $2^{\circ} \mathrm{de}$ la organización Montoneros, responsable de la prensa sindical, y su nombre de guerra era Hilda. Efectivamente estaba reunida ese día con cuatro miembros de la Secretaría Política que combatieron y murieron con ella.

La forma en la que ingresó a Montoneros no la conozco en detalle. A la edad de 22 años, edad de su probable ingreso, se distinguía por sus decisiones firmes y claras. Por esa época comenzó a trabajar en el diario La Opinión y en un tiempo muy breve se convirtió en periodista.

El periodismo en si no le interesaba. Sus compañeros la eligieron delegada sindical. Como tal debió enfrentar en un conflicto difícil al director del diario, Jacobo Timerman, a quien despreciaba profundamente. El conflicto se perdió 
y cuando Timerman empezó a denunciar como guerrilleros a sus propios periodistas, ella pidió licencia y no volvió más.

Fue a militar a una villa miseria. Era su primer contacto con al pobreza extrema en cuyo nombre combatía. Salió de esa experiencia convertida a un ascetismo que impresionaba. Su marido, Emiliano Costa, fue detenido a principios de 1975 y no lo vio más. La hija de ambos nació poco después.

El último año de mi hija fue muy duro. El sentido del deber la llevó a relegar toda gratificación individual, a empeñarse mucho más allá de sus fuerzas físicas. Como tantos muchachos que repentinamente se volvieron adultos, anduvo a los saltos, huyendo de casa en casa. No se quejaba. Sólo su sonrisa se volvía un poco más desvaída.

En las últimas semanas varios de sus compañeros fueron muertos; no pudo detenerse a llorarlos. La embargaba una terrible urgencia por crear medios de comunicación en el frente sindical, que era su responsabilidad. Nos veíamos una vez por semana; cada quince días. Eran entrevistas cortas, caminando por la calle, quizás diez minutos en el banco de una plaza. Hacíamos planes para vivir juntos, para tener una casa donde hablar, recordar, estar juntos en silencio. Presentíamos, sin embargo, que eso no iba a ocurrir, que uno de esos fugaces encuentros iba a ser el último, y nos despedíamos simulando valor, consolándonos de la anticipada pérdida.

Mi hija estaba dispuesta a no entregarse con vida. Era una decisión 
madurada, razonada. Conocía, por infinidad de testimonios, el trato que dispensan los militares y marinos a quienes tienen la desgracia de caer prisioneros; el despellejamiento en vida, la mutilación de los miembros, la tortura sin límites en el tiempo ni en el método, que procura al mismo tiempo la degradación moral y la delación.

Sabía perfectamente que en una guerra de esas características, el pecado no era hablar, sino caer. Llevaba siempre encima una pastilla de cianuro - la misma con que se mató nuestro amigo Paco Urondo- con la que tantos otros habían obtenido una victoria sobre la barbarie.

El 28 de setiembre, cuando entró en la casa de la calle Corro, cumplía 26 años. Llevaba en brazos a su hija porque a último momento no encontró con quien dejarla. Se acostó con ella, en camisón. Usaba unos absurdos camisones blancos que siempre le quedaban grandes.

A las 7 del 29 la despertaron los altavoces del Ejército, los primeros tiros. Siguiendo el plan de defensa acordado, subió a la terraza con el Secretario Político Molina, mientras Coronel, Salame y Beltrán respondían al fuego desde la planta baja. He visto la escena con sus ojos: la terraza sobre las casa bajas, el cielo amaneciendo, y el cerco. El cerco de 150 hombres, los FAP emplazados, el tanque.

Me ha llegado el testimonio de uno de esos hombres, un conscripto: -El combate duró más de una hora y media. Un hombre y una muchacha tiraban 
de arriba. Nos llamó la atención la muchacha, porque cada vez que tiraba una ráfaga y nosotros nos zambullíamos, ella se reía.

He tratado de entender esa risa. La metralleta era una Halcón y mi hija nunca había tirado con ella aunque conociera su manejo por las clases de instrucción. Las cosas nuevas, sorprendentes, siempre la hicieron reír. Sin duda era nuevo y sorprendente para ella que ante una simple pulsación del dedo brotara una ráfaga y que ante esa ráfaga 150 hombres se zambulleran sobre los adoquines empezando por el coronel Roualdes, jefe del operativo.

A los camiones y el tanque se sumó un helicóptero que giraba alrededor de la terraza, contenido por el fuego. -De pronto - dice el soldado- hubo un silencio. La muchacha dejó la metralleta, se asomó de pie sobre el parapeto y abrió los brazos. Dejamos de tirar sin que nadie lo ordenara y pudimos verla bien. Era flaquita, tenía el pelo corto y estaba en camisón. Empezó a hablarnos en voz alta pero muy tranquila. No recuerdo todo lo que dijo. Pero recuerdo la última frase; en realidad no me deja dormir. -Ustedes no nos matan - dijo- nosotros elegimos morir. Entonces ella y el hombre se llevaron una pistola a la sien y se mataron frente a todos nosotros.

Abajo ya no había resistencia. El coronel abrió la puerta y tiró una granada. Después entraron los oficiales. Encontraron una nena de algo más de un año, sentadita en una cama, y cinco cadáveres. 
En el tiempo transcurrido he reflexionado sobre esa muerte. Me he preguntado si mi hija, si todos los que mueren como ella, tenían otro camino. La respuesta brota desde lo más profundo de mi corazón y quiero que mis amigos la conozcan. Vicki pudo elegir otros caminos que eran distintos sin ser deshonrosos, pero el que eligió era el más justo, el más generoso, el más razonado. Su lúcida muerte es una síntesis de su corta, hermosa vida. No vivió para ella, vivió para otros, y esos otros son millones.

Su muerte sí, su muerte fue gloriosamente suya, y en ese orgullo me afirmo y soy quien renace en ella.

Esto es lo quería decir a mis amigos y lo que desearía que ellos transmitieran a otros por los medios que su bondad les dicte.

Rodolfo Walsh 


\section{CARTA ABIERTA A LA JUNTA MILITAR}

1. La censura de prensa, la persecución a intelectuales, el allanamiento de mi casa en el Tigre, el asesinato de amigos queridos y la pérdida de una hija que murió combatiéndolos, son algunos de los hechos que me obligan a esta forma de expresión clandestina después de haber opinado libremente como escritor y periodista durante casi treinta años.

El primer aniversario de esta Junta Militar ha motivado un balance de la acción de gobierno en documentos y discursos oficiales, donde lo que ustedes llaman aciertos son errores, los que reconocen como errores son crímenes y lo que omiten son calamidades.

El 24 de marzo de 1976 derrocaron ustedes a un gobierno del que formaban parte, a cuyo desprestigio contribuyeron como ejecutores de su política represiva, y cuyo término estaba señalado por elecciones convocadas para nueve meses más tarde. En esa perspectiva lo que ustedes liquidaron no fue el mandato transitorio de Isabel Martínez sino la posibilidad de un proceso democrático donde el pueblo remediara males que ustedes continuaron y agravaron.

llegítimo en su origen, el gobierno que ustedes ejercen pudo legitimarse en los hechos recuperando el programa en que coincidieron en las elecciones de 1973 el ochenta por ciento de los argentinos y que sigue en pie como 
expresión objetiva de la voluntad del pueblo, único significado posible de ese "ser nacional" que ustedes invocan tan a menudo.

Invirtiendo ese camino han restaurado ustedes la corriente de ideas e intereses de minorías derrotadas que traban el desarrollo de las fuerzas productivtas, explotan al pueblo y disgregan la Nación. Una política semejante sólo puede imponerse transitoriamente prohibiendo los partidos, interviniendo los sindicatos, amordazando la prensa e implantando el terror más profundo que ha conocido la sociedad argentina.

2. Quince mil desaparecidos, diez mil presos, cuatro mil muertos, decenas de miles de desterrados son la cifra desnuda de ese terror.

Colmadas las cárceles ordinarias, crearon ustedes en las principales guarniciones del país virtuales campos de concentración donde no entra ningún juez, abogado, periodista, observador internacional. El secreto militar de los procedimientos, invocado como necesidad de la investigación, convierte a la mayoría de las detenciones en secuestros que permiten la tortura sin límite y el fusilamiento sin juicio.

Más de siete mil recursos de hábeas corpus han sido contestados negativamente este último año. En otros miles de casos de desaparición el recurso ni siquiera se ha presentado porque se conoce de antemano su 
inutilidad o porque no se encuentra abogado que ose presentarlo después que los cincuenta o sesenta que lo hacían fueron a su turno secuestrados.

De este modo han despojado ustedes a la tortura de su límite en el tiempo. Como el detenido no existe, no hay posibilidad de presentarlo al juez en diez días según manda un ley que fue respetada aún en las cumbres represivas de anteriores dictaduras.

La falta de límite en el tiempo ha sido complementada con la falta de límite en los métodos, retrocediendo a épocas en que se operó directamente sobre las articulaciones y las vísceras de las víctimas, ahora con auxiliares quirúrgicos y farmacológicos de que no dispusieron los antiguos verdugos. El potro, el torno, el despellejamiento en vida, la sierra de los inquisidores medievales reaparecen en los testimonios junto con la picana y el "submarino", el soplete de las actualizaciones contemporáneas.

Mediante sucesivas concesiones al supuesto de que el fin de exterminar a la guerilla justifica todos los medios que usan, han llegado ustedes a la tortura absoluta, intemporal, metafísica en la medida que el fin original de obtener información se extravía en las mentes perturbadas que la administran para ceder al impulso de machacar la sustancia humana hasta quebrarla y hacerle perder la dignidad que perdió el verdugo, que ustedes mismos han perdido. 
3. La negativa de esa Junta a publicar los nombres de los prisioneros es asimismo la cobertura de una sistemática ejecución de rehenes en lugares descampados y horas de la madrugada con el pretexto de fraguados combates e imaginarias tentativas de fuga.

Extremistas que panfletean el campo, pintan acequias o se amontonan de a diez en vehículos que se incendian son los estereotipos de un libreto que no está hecho para ser creído sino para burlar la reacción internacional ante ejecuciones en regla mientras en lo interno se subraya el carácter de represalias desatadas en los mismos lugares y en fecha inmediata a las acciones guerrilleras.

Setenta fusilados tras la bomba en Seguridad Federal, 55 en respuesta a la voladura del Departamento de Policía de La Plata, 30 por el atentado en el Ministerio de Defensa, 40 en la Masacre del Año Nuevo que siguió a la muerte del coronel Castellanos, 19 tras la explosión que destruyó la comisaría de Ciudadela forman parte de 1.200 ejecuciones en 300 supuestos combates donde el oponente no tuvo heridos y las fuerzas a su mando no tuvieron muertos.

Depositarios de una culpa colectiva abolida en las normas civilizadas de justicia,incapaces de influir en la política que dicta los hechos por los cuales son represaliados, muchos de esos rehenes son delegados sindicales, intelectuales, familiares de guerrilleros, opositores no armados, simples sospechosos a los que se mata para equilibrar la balanza de las bajas según 
la doctrina extranjera de "cuenta-cadáveres" que usaron los SS en los países ocupados y los invasores en Vietnam.

El remate de guerrilleros heridos o capturados en combates reales es asimismo una evidencia que surge de los comunicados militares que en un año atribuyeron a la guerrilla 600 muertos y sólo 10 ó 15 heridos, proporción desconocida en los más encarnizados conflictos. Esta impresión es confirmada por un muestreo periodístico de circulación clandestina que revela que entre el 18 de diciembre de 1976 y el 3 de febrero de 1977, en 40 acciones reales, las fuerzas legales tuvieron 23 muertos y 40 heridos, y la guerrilla 63 muertos.

Más de cien procesados han sido igualmente abatidos en tentativas de fuga cuyo relato oficial tampoco está destinado a que alguien lo crea sino a prevenir a la guerrilla y los partidos de que aún los presos reconocidos son la reserva estratégica de las represalias de que disponen los Comandantes de Cuerpo según la marcha de los combates, la conveniencia didáctica o el humor del momento.

Así ha ganado sus laureles el general Benjamín Menéndez, jefe del Tercer Cuerpo de Ejército, antes del 24 de marzo con el asesinato de Marcos Osatinsky, detenido en Córdoba, después con la muerte de Hugo Vaca Narvaja y otros cincuenta prisioneros en variadas aplicaciones de la ley de fuga ejecutadas sin piedad y narradas sin pudor. 
El asesinato de Dardo Cabo, detenido en abril de 1975, fusilado el 6 de enero de 1977 con otros siete prisioneros en jurisdicción del Primer Cuerpo de Ejército que manda el general Suárez Masson, revela que estos episodios no son desbordes de algunos centuriones alucinados sino la política misma que ustedes planifican en sus estados mayores, discuten en sus reuniones de gabinete, imponen como comandantes en jefe de las 3 Armas y aprueban como miembros de la Junta de Gobierno.

4. Entre mil quinientas y tres mil personas han sido masacradas en secreto después que ustedes prohibieron informar sobre hallazgos de cadáveres que en algunos casos han trascendido, sin embargo, por afectar a otros países, por su magnitud genocida o por el espanto provocado entre sus propias fuerzas.

Veinticinco cuerpos mutilados afloraron entre marzo y octubre de 1976 en las costas uruguayas, pequeña parte quizás del cargamento de torturados hasta la muerte en la Escuela de Mecánica de la Armada, fondeados en el Río de la Plata por buques de esa fuerza, incluyendo el chico de 15 años, Floreal Avellaneda, atado de pies y manos, "con lastimaduras en la región anal y fracturas visibles" según su autopsia.

Un verdadero cementerio lacustre descubrió en agosto de 1976 un vecino que buceaba en el Lago San Roque de Córdoba, acudió a la comisaría donde no le recibieron la denuncia y escribió a los diarios que no la publicaron. 
Treinta y cuatro cadáveres en Buenos Aires entre el 3 y el 9 de abril de 1976, ocho en San Telmo el 4 de julio, diez en el Río Luján el 9 de octubre, sirven de marco a las masacres del 20 de agosto que apilaron 30 muertos a 15 kilómetros de Campo de Mayo y 17 en Lomas de Zamora.

En esos enunciados se agota la ficción de bandas de derecha, presuntas herederas de las 3 A de López Rega, capaces dc atravesar la mayor guarnición del país en camiones militares, de alfombrar de muertos el Río de la Plata o de arrojar prisioneros al mar desde los transportes de la Primera Brigada Aérea $\underline{7}$, sin que se enteren el general Videla, el almirante Massera $o$ el brigadier Agosti. Las 3 A son hoy las 3 Armas, y la Junta que ustedes presiden no es el fiel de la balanza entre "violencias de distintos signos" ni el árbitro justo entre "dos terrorismos", sino la fuente misma del terror que ha perdido el rumbo y sólo puede balbucear el discurso de la muerte.

La misma continuidad histórica liga el asesinato del general Carlos Prats, durante el anterior gobierno, con el secuestro y muerte del general Juan José Torres, Zelmar Michelini, Héctor Gutiérrez Ruíz y decenas de asilados en quienes se ha querido asesinar la posibilidad de procesos democráticos en Chile, Boliva y Uruguay.

La segura participación en esos crímenes del Departamento de Asuntos Extranjeros de la Policía Federal, conducido por oficiales becados de la CIA a través de la AID, como los comisarios Juan Gattei y Antonio Gettor, sometidos ellos mismos a la autoridad de Mr. Gardener Hathaway, Station Chief de la 
CIA en Argentina, es semillero de futuras revelaciones como las que hoy sacuden a la comunidad internacional que no han de agotarse siquiera cuando se esclarezcan el papel de esa agencia y de altos jefes del Ejército, encabezados por el general Menéndez, en la creación de la Logia Libertadores de América, que reemplazó a las 3 A hasta que su papel global fue asumido por esa Junta en nombre de las 3 Armas.

Este cuadro de exterminio no excluye siquiera el arreglo personal de cuentas como el asesinato del capitán Horacio Gándara, quien desde hace una década investigaba los negociados de altos jefes de la Marina, o del periodista de "Prensa Libre" Horacio Novillo apuñalado y calcinado, después que ese diario denunció las conexiones del ministro Martínez de Hoz con monopolios internacionales.

A la luz de estos episodios cobra su significado final la definición de la guerra pronunciada por uno de sus jefes: "La lucha que libramos no reconoce límites morales ni naturales, se realiza más allá del bien y del mal".

5. Estos hechos, que sacuden la conciencia del mundo civilizado, no son sin embargo los que mayores sufrimientos han traído al pueblo argentino ni las peores violaciones de los derechos humanos en que ustedes incurren. En la política económica de ese gobierno debe buscarse no sólo la explicación de sus crímenes sino una atrocidad mayor que castiga a millones de seres humanos con la miseria planificada. 
En un año han reducido ustedes el salario real de los trabajadores al 40\%, disminuido su participación en el ingreso nacional al 30\%, elevado de 6 a 18 horas la jornada de labor que necesita un obrero para pagar la canasta familiar, resucitando así formas de trabajo forzado que no persisten ni en los últimos reductos coloniales.

Congelando salarios a culatazos mientras los precios suben en las puntas de las bayonetas, aboliendo toda forma de reclamación colectiva, prohibiendo asambleas y comisioncs internas, alargando horarios, elevando la desocupación al récord del 9\% prometiendo aumentarla con 300.000 nuevos despidos, han retrotraído las relaciones de producción a los comienzos de la era industrial, y cuando los trabajadores han querido protestar los han calificados de subversivos, secuestrando cuerpos enteros de delegados que en algunos casos aparecieron muertos, y en otros no aparecieron.

Los resultados de esa política han sido fulminantes. En este primer año de gobierno el consumo de alimentos ha disminuido el $40 \%$, el de ropa más del 50\%, el de medicinas ha desaparecido prácticamente en las capas populares. Ya hay zonas del Gran Buenos Aires donde la mortalidad infantil supera el $30 \%$, cifra que nos iguala con Rhodesia, Dahomey o las Guayanas; enfermedades como la diarrea estival, las parasitosis y hasta la rabia en que las cifras trepan hacia marcas mundiales o las superan. Como si esas fueran metas deseadas y buscadas, han reducido ustedes el presupuesto de la salud pública a menos de un tercio de los gastos militares, suprimiendo hasta 
los hospitales gratuitos mientras centenares de médicos, profesionales y técnicos se suman al éxodo provocado por el terror, los bajos sueldos o la "racionalización".

Basta andar unas horas por el Gran Buenos Aires para comprobar la rapidez con que semejante política la convirtió en una villa miseria de diez millones de habitantes. Ciudades a media luz, barrios enteros sin agua porque las industrias monopólicas saquean las napas subtérráneas, millares de cuadras convertidas en un solo bache porque ustedes sólo pavimentan los barrios militares y adornan la Plaza de Mayo, el río más grande del mundo contaminado en todas sus playas porque los socios del ministro Martínez de Hoz arrojan en él sus residuos industriales, y la única medida de gobierno que ustedes han tomado es prohibir a la gente que se bañe.

Tampoco en las metas abstractas de la economía, a las que suelen llamar "el país", han sido ustedes más afortutunados. Un descenso del producto bruto que orilla el 3\%, una deuda exterior que alcanza a 600 dólares por habitante, una inflación anual del 400\%, un aumento del circulante que en solo una semana de diciembre llegó al 9\%, una baja del 13\% en la inversión externa constituyen también marcas mundiales, raro fruto de la fría deliberación y la cruda inepcia.

Mientras todas las funciones creadoras y protectoras del Estado se atrofian hasta disolverse en la pura anemia, una sola crece y se vuelve autónoma. Mil 
ochocientos millones de dólares que equivalen a la mitad de las exportaciones argentinas presupuestados para Seguridad y Defensa en 1977, cuatro mil nuevas plazas de agentes en la Policía Federal, doce mil en la provincia de Buenos Aires con sueldos que duplican el de un obrero industrial y triplican el de un director de escuela, mientras en secreto se elevan los propios sueldos militares a partir de febrero en un $120 \%$, prueban que no hay congelación ni desocupación en el reino de la tortura y de la muerte, único campo de la actividad argentina donde el producto crece y donde la cotización por guerrillero abatido sube más rápido que el dólar.

6. Dictada por el Fondo Monetario Internacional según una receta que se aplica indistintamente al Zaire o a Chile, a Uruguay o Indonesia, la política económica de esa Junta sólo reconoce como beneficiarios a la vieja oligarquía ganadera, la nueva oligarquía especuladora y un grupo selecto de monopolios internacionales encabezados por la ITT, la Esso, las automotrices, la U.S.Steel, la Siemens, al que están ligados personalmente el ministro Martínez de Hoz y todos los miembros de su gabinete.

Un aumento del 722\% en los precios de la producción animal en 1976 define la magnitud de la restauración oligárquica emprendida por Martínez de Hoz en consonancia con el credo de la Sociedad Rural expuesto por su presidente Celedonio Pereda: "Llena de asombro que ciertos grupos pequeños pero activos sigan insistiendo en que los alimentos deben ser baratos". 
El espectáculo de una Bolsa de Comercio donde en una semana ha sido posible para algunos ganar sin trabajar el cien y el doscientos por ciento, donde hay empresas que de la noche a la mañana duplicaron su capital sin producir más que antes, la rueda loca de la especulación en dólares, letras, valores ajustables, la usura simple que ya calcula el interés por hora, son hechos bien curiosos bajo un gobierno que venía a acabar con el "festín de los corruptos".

Desnacionalizando bancos se ponen el ahorro y el crédito nacional en manos de la banca extranjera, indemnizando a la ITT y a la Siemens se premia a empresas que estafaron al Estado, devolviendo las bocas de expendio se aumentan las ganancias de la Shell y la Esso, rebajando los aranceles aduaneros se crean empleos en Hong Kong o Singapur y desocupación en la Argentina. Frente al conjunto de esos hechos cabe preguntarse quiénes son los apátridas de los comunicados oficiales, dónde están los mercenarios al servicio de intereses foráneos, cuál es la ideologia que amenaza al ser nacional.

Si una propaganda abrumadora, reflejo deforme de hechos malvados no pretendiera que esa Junta procura la paz, que el general Videla defiende los derechos humanos o que el almirante Massera ama la vida, aún cabría pedir a los señores Comandantes en Jefe de las 3 Armas que meditaran sobre el abismo al que conducen al país tras la ilusión de ganar una guerra que, aún si mataran al último guerrillero, no haría más que empezar bajo nuevas 
formas, porque las causas que hace más de veinte años mueven la resistencia del pueblo argentino no estarán dcsaparecidas sino agravadas por el recuerdo del estrago causado y la revelación de las atrocidades cometidas.

Estas son las reflexiones que en el primer aniversario de su infausto gobierno he querido hacer llegar a los miembros de esa Junta, sin esperanza de ser escuchado, con la certeza de ser perseguido, pero fiel al compromiso que asumí hace mucho tiempo de dar testimonio en momentos difíciles.

Rodolfo Walsh. - C.I. 2845022

Buenos Aires, 24 de marzo de 1977. 